\title{
GEOHYDRAULICS AT THE UNCONFORMITY BETWEEN BEDROCK AND ALLUVIAL AQUIFERS
}

Completion Report

OWRR Project No. B-022 COLO

by

\author{
J. P. Wa1tz \\ Department of Geology \\ Colorado State University \\ and \\ D. K. Sunada \\ Department of Civil Engineering \\ Colorado State University \\ Submitted to \\ Office of Water Resources Research \\ U.S. Department of the Interior \\ Washington, D.C. 20240 \\ June 30, 1972
}

The work upon which this report is based was supported in part by funds provided by the United States Department of the Interior, Office of Water Resources Research, as authorized under the Water Resources

Research Act of 1964, Public Law 88-379, Agreement Number 14-01-0001-1881 (July 1, 1968 to June 30, 1972).

\section{Environmental Resources Center \\ Colorado State University \\ Fort Collins, Colorado}

Norman A. Evans, Director 


\section{Abstract}

Three legally designated groundwater basins in Colorado have been studied to determine the magnitude of groundwater flux into or out of the underlying bedrock. A numerical model based on Darcy's Law and the mass continuity equation was employed to describe the flow of groundwater within each basin. The model was applied to the analysis of interbasin groundwater flow by assuming that no leakage occurs at the base of the alluvial aquifer. Where leakage does occur, the model produces anomalous results in the form of erroneous water level elevations. The magnitude of the anomalies is used to calculate the rate of the interbasin groundwater flux. fluxes:

The model studies revealed the following interbasin groundwater

1. Loss from Black Squirrel Basin is approximately 5,350 acre-feet/year.

2. Loss from High Plains Basin is approximately 75,000 acre-feet/year.

3. Gain to Kiowa-Bijou Basin is approximately 19,000 acre-feet/year.

Data requirements for the application of the model to groundwater basin are presented and procedures for qualitative evaluation of interbasin groundwater flux are discussed. 
I. INTRODUCTION . . . . . . . . . . . . . . . . 1

Objectives of the Study ................ . . 4

Reports Available .................. . 5

II. DESCRIPTION OF MATHEMATICAL MODEL . . . . . . . . . . . . 6

Procedure . . . . . . . . . . . . . . . . . . . 6

Description of the Mathematical Model . . . . . . . . . 6

General Requirements of Model to Study Leaky Aquifer

Conditions . . . . . . . . . . . . . . . . . 10

III. APPLICATION OF NUMERICAL MODEL - STATISTICAL ANALYSIS OF

DATA REQUIREMENTS . . . . . . . . . . . . . . . . . . . . 14

Numerical Model . . . . . . . . . . . . . . . . 15

Theoretical Framework . . . . . . . . . . . . . 15

Experimental Procedure . . . . . . . . . . . . . . 18

IV. APPLICATION OF NUMERICAL MODEL - KIOWA-BIJOU BASIN . . . . . 23

Location and Description of the Kiowa-Bijou Basin . . . . 23

Review of Literature on the Kiowa-Bijou Basin . . . . . . 26

Geology and Hydrogeology of the Kiowa-Bijou Basin . . . 28

Mathematical Model as Applied to the Kiowa-Bijou Basin . . 31

Discussion of Results ... . . . . . . . . . . . . . . 40

Conclusions for the Kiowa-Bijou Basin . . . . . . . . . . 47

V. APPLICATION OF NUMERICAL MODEL - BLACK SQUIRREL BASIN . . . 49

Location of the Black Squirrel Basin . . . . . . . . . . . 49

Previous Investigations . . . . . . . . . . . . . . 49

Geology . . . . . . . . . . . . . . . . . . 51

Data Used . . . . . . . . . . . . . . . . . . 62

Discussion of Results . . . . . . . . . . . . . 68

Conclusions for the Black Squirrel Basin . . . . . . . . . 73

VI. HIGH PLAINS GROUND WATER BASIN . . . . . . . . . . . . . 75

Description of Problem . . . . . . . . . . . . . . . 75

Method of Calculating Net Recharge . . . . . . . . . . . . 77

Net Natural Discharge Along a Line from Southeastern

Sedgwick County to 18 Miles South of Akron . . . . . . . 77

VII. GEOLOGIC DETAIL - BEDROCK STRATA INVOLVED IN GROUNDWATER

TRANSFER FROM THE BLACK SQUIRREL BASIN TO THE KIOWA-

BIJOU BASIN . . . . . . . . . . . . . . . . . . . 81

Methods of Investigation . . . . . . . . . . . . . . 81

Geophysical Well Logs . . . . . . . . . . . . . . . . 82

Summary of Stratigraphic Characteristics . . . . . . . . . 101

Conclusions . . . . . . . . . . . . . . . 102 
VIII.GEOLOGIC DETAIL - BEDROCK STRATA INVOLVED IN GROUNDWATER TRANSFER FROM THE HIGH PLAINS BASIN INTO THE SOUTH

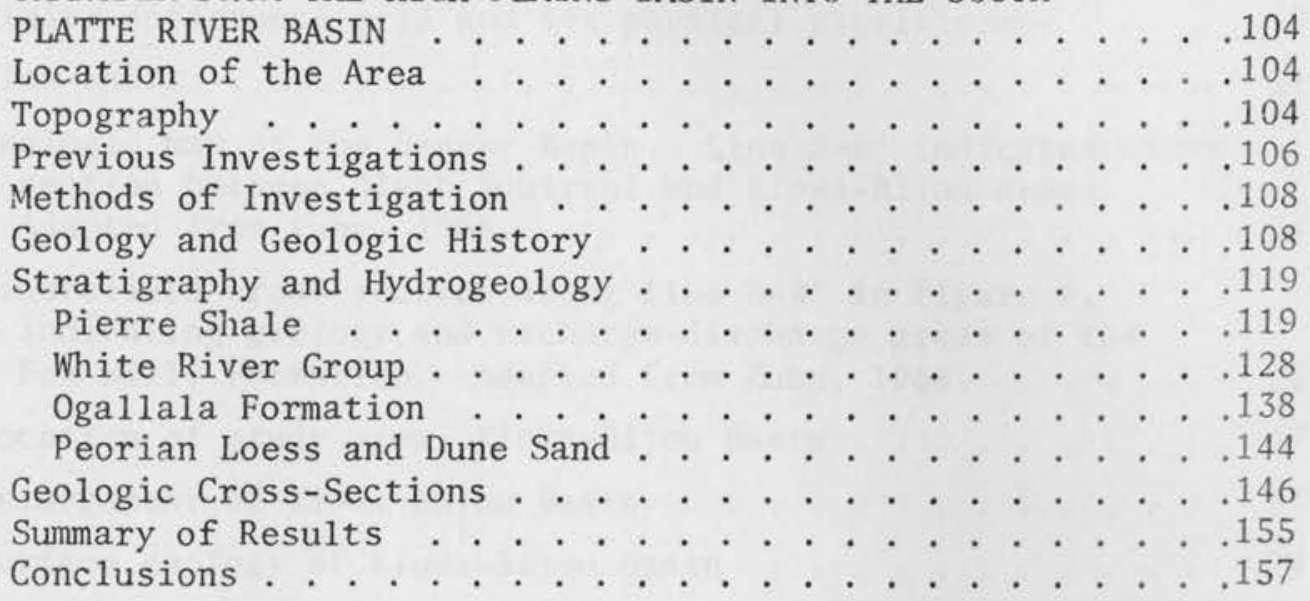

IX. SUMMARY OF RESULTS AND CONCLUSIONS . . . . . . . . . . . . . . .

BIBLIOGRAPHY . . . . . . . . . . . . . . . . . . 164 


\section{LIST OF FIGURES}

Figure

$\underline{\text { Page }}$

1. Location of the three ground water basins in Colorado. . . 2

2. Finite difference grid and its physical significance . . . 9

3. Flow chart. . . . . . . . . . . . . . . . . . . . . . 11

4. Geologic map of the Denver Basin. Line $B_{-} B^{\prime}$ indicates cross section between Black Squirrel and Kiowa-Bijou areas. Adapted from Kuhn, 1968. . . . . . . . . . . . . . . . 24

5. Generalized cross section along line $\mathrm{B}^{-\mathrm{B}^{\prime}}$ in figure 4 , indicating geology and recharge-discharge areas of the Fox Hills Formation. Adapted from Kuhn, 1968. . . . . . 25

6. Location of study area, Kiowa-Bijou Basin . . . . . . . . . 27

7. Enlargement of Kiowa-Bijou Basin . . . . . . . . . . . . . 27

8. Surface geology of Kiowa-Bijou Basin . . . . . . . . . . . 29

9. Diagrammatic vertical section A-B, from figure 8 . . . . 30

10. Grid overlaying Fox Hills sandstone and saturated alluvium. 33

11. Areas showing discrepancies between computed and actual drawdown . . . . . . . . . . . . . . . . . 42

12. Location of Black Squirrel Basin . . . . . . . . . . . 50

13. Geology of Black Squirrel Basin . . . . . . . . . . . . . 53

14. North-South geologic cross section through Black Squirrel

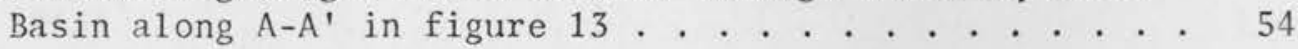

15. Generalized Stratigraphic Column of Strata in Black Squirrel Creek Basin. After Kuhn, 1968, and Reichert, 1956 . . 55

16. Areas showing discrepancies between computed and actual drawdown . . . . . . . . . . . . . . 71

17. Reddell's negative recharge area in the High Plains . . . . 76

18. Relation between subsurface extent of the White River Group and a major groundwater discharge area . . . . . . . . .

19. Geologic cross section of the northern part of the Northern High Plains indicating a hypothetical possibility for subsurface discharge from the Ogallala Formation into the White River Group . . . . . . . . . . . . . . . . . . . .

20. Distribution of geophysical well $\log$ s with selected $\log$ correlations in the Black Squirrel Basin . . . . . . . . 84

21. Typical electric 10 grom Black Squirrel Basin . . . . . . 86

22. Measured sections from Corral Bluffs outcrop. Section A: T14S R64W Sec. 8 Section B: T14S R64W Sec. 5.... 90

23. Commercial oil well logs. See figure 19 for locations, and figure 20 for formation designations . . . . . . . . . 


\section{LIST OF FIGURES - 2}

$\underline{\text { Figure }}$

$\underline{\text { Page }}$

24. Commercial oil well logs. See figure 19 for locations and figure 20 for formation designations. . . . . . . . . . .

25. Log correlation A-A'. See figure 21 for formation symbols. Also figure 20 for cross-section location . . . . . . . .

26. Log correlation B-B'. See figure 21 for formation symbols. Also figure 20 for cross-section location . . . . . . .

27. Log correlation C-C'. See figure 21 for formation symbols. Also figure 20 for cross-section location . . . . . .

28. Log correlation D-1)'. See figure 21 for formation symbols. Also figure 20 for cross-section location . . . . . . 100

29. Location Map of Study Area . . . . . . . . . . . . . . . . 105

30. Surface geology map . . . . . . . . . . . . . . . . . . 109

31. Subsurface extent of the Tertiary Ogallala Formation and White River Group . . . . . . . . . . . . . 110

32. Generalized columnar section of the study area . . . . . . 111

33. Local structure contour map on the base of the Pierre Shale 113

34. Bedrock contour map on the top of the White River Group or the Pierre Shale. . . . . . . . . . . . . . 117

35. Map showing the lateral extent of the sandstones within the Hygiene Member of the Pierre Shale. (Adapted from Nolte, 1963). . . . . . . . . . . . . . .

36. Local continuity of an aquifer sand within the Transition Member .. . . . . . . . . . . . . . . . 124

37. Electric $\log$ illustrating an unconformable contact between a gravel unit within the Ogallala Formation and the Transition Member . . . . . . . . . . . . . . . . 126

38. Subsurface electric log correlation map, showing the continuity of the Transition Member across the study area . . 127

39. Piezometric surface map for the White River Group channel deposits, south and west of Akron . . . . . . . . . 136

40. Subsurface gamma $\log$ correlation map, showing the continuity of the White River Group . . . . . . . . . . . . . 137

41. Electric log showing a characteristically high resistivity for the White River channel deposits . . . . . . . . . 139

42. Water table map of the Ogallala Formation (1965) . . . . . 142

43. Electric logs, showing the local correlation of gravel lenses within the Ogallala Formation in the subsurface . . . . . 145

44. Location map for stratigraphic cross-sections . . . . . . . 147

45. Cross-section $\mathrm{A}-\mathrm{A}^{\prime}$, looking to the northeast . . . . . 148 


\section{LIST OF FIGURES - 3}

$\underline{\text { Figure }}$

$\underline{\text { Page }}$

46. Cross-section B-B', looking to the northeast . . . . . 149

47. Cross-section C-C', looking to the northeast . . . . . . 150

48. Cross-section D-D', looking West along R50W . . . . . . . 151

49. Cross-section E-E', looking West along R48W . . . . . . . 152

50. Cross-section F-F', looking West along R47W . . . . . . . . 153

51. Cross-section $\mathrm{G}_{-} \mathrm{G}^{\prime}$, looking West along R44W . . . . . . . . 154

\section{LIST OF TABLES}

Table

1. Actual and Computed Changes in Water Table Elevation in Feet $(1962-65)$. . . . . . . . . . . . . . . . .

2. Difference in feet between actual and computed water table elevations in each grid for 1966-1970. . . . . . . . . 


\section{INTRODUCTION}

The increasing demands on Colorado's ground water resources have brought parallel increases in problems of ground water management. To alleviate some of these management problems, Colorado legislators passed the Colorado Ground Water Management Act of 1965. This Act provides for the establishment of "Designated" Ground Water Basins in the state so that equitable water management policies can be formulated within each basin. For a basin to become "Designated". information must be assembled on the geographic boundaries of the basin, the size, shape and water-storing characteristics of all aquifers within the basin, the annual recharge to these aquifers, and the present and projected withdrawals from these aquifers.

Fundamental to the concept of a Designated Ground Water Basin is the isolation of water. That is, a minimum of surface and/or ground water should flow from one basin to another. Where basin boundaries can be established such that water transfer is minimized or accounted for, it is feasible to determine the availability of water in the basin and to develop appropriate management policies.

Six Designated Ground Water Basins have been established in Colorado since 1965 under the provisions of the Ground Water Management Act. Three of these basins, however, have geologic and hydraulic characteristics which may partially invalidate the purpose of the ground water management act. This report indicates that appreciable volumes of water may pass through the contact between the alluvial aquifers and the supposedly impermeable bedrock in the High Plains, Kiowa-Bijou, and Black Squirre1 Designated Basins of Colorado. The locations of these Colorado Basins are given in Figure 1. 


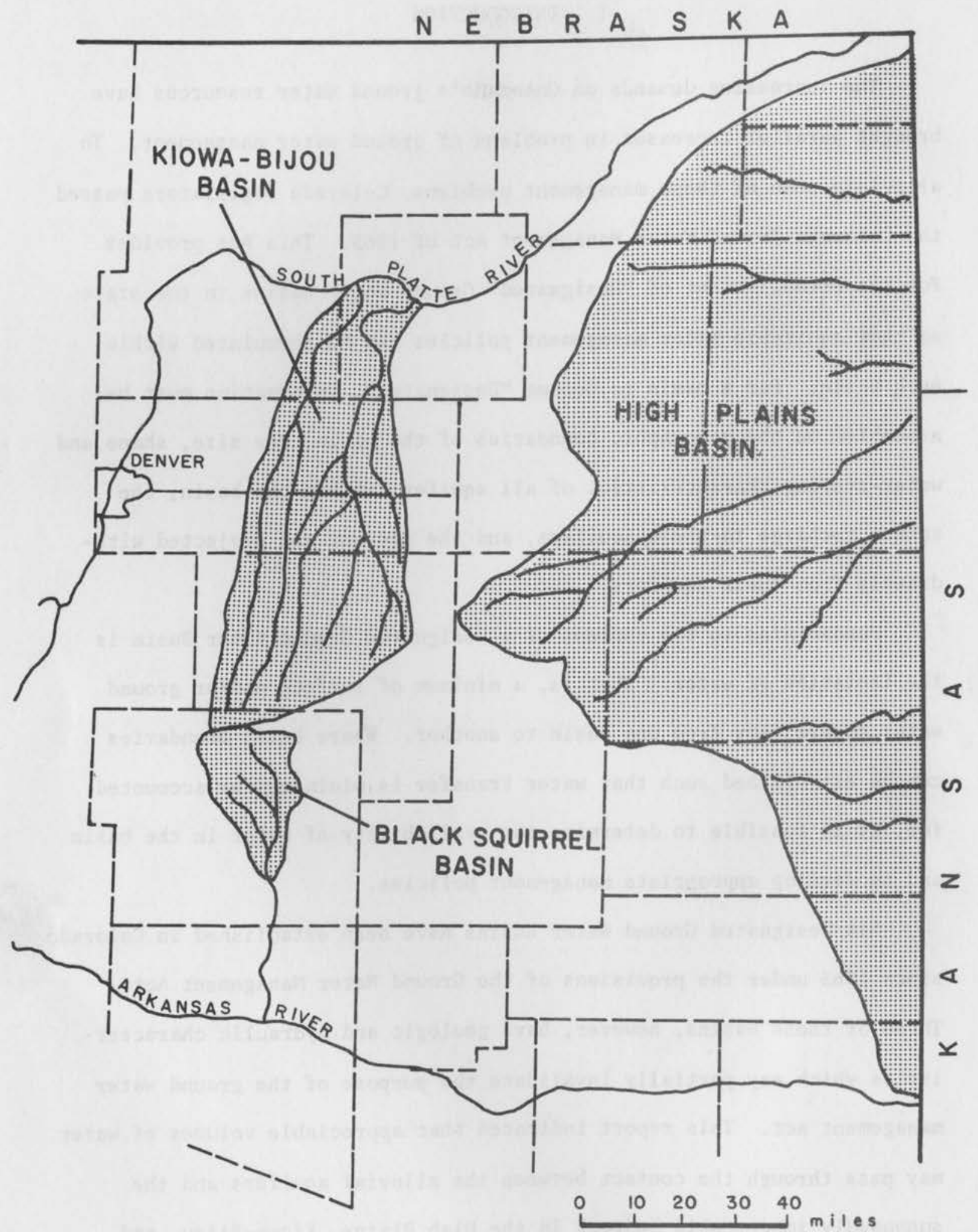

Figure 1. Location of the three ground water basins in Colorado. 
Definition of aquifers in a basin is usually in terms of the economic feasibility of ground water extraction. That is, the proposed use of the water may determine what is to be called an aquifer. In the designated Basins of Colorado, the principle uses of ground water are irrigation and municipal. Thus, a geologic formation in these basins which delivers only $50-100 \mathrm{gpm}$ to a well may not be classified as an aquifer. Such a formation, then, would not receive particular scrutiny during the data collection or evaluation processes that are required in the "designation" of a ground water basin. "Bedrock" formations, because of relatively low permeability as compared to alluvial formation, are usually considered to be impermeable.

Although some bedrock formations may not qualify as aquifers in the sense of economic well operation, these formations may transmit appreciable volumes of water into or out of a designated basin or resource area. Hence, the assumption that "bedrock" in a designated basin can be considered as an impermeable boundary may not be valid.

To test the validity of this assumption, a regional view of geologic, topographic and hydrologic conditions must be brought into focus. Slow seepage of ground water through the relatively low permeability bedrock may be unimportant locally, but the aggregate effect of this seepage into or out of the basin as a whole may need to be taken into consideration when, for example, management policies are to be projected for severa1 decades.

The mechanism of regional groundwater flow involves both the geologic framework and the hydraulic conditions which are superimposed on this framework. It is essential, therefore, that evaluation of regional groundwater movement be approached in an interdisciplinary manner. 
Neither geology nor engineering sciences alone could adequately describe or evaluate the complex process of regional groundwater movement through the geologic framework.

\section{Objectives of the Study}

1. Determine the magnitude of water flux into or out of bedrock in three designated ground water basins in Colorado: Kiowa-Bijou Basin, High Plains Basin, and Black Squirrel Basin.

The determinations are to be based primarily on existing geo$\operatorname{logic}$ hydrologic, and topographic data. Where existing data are inadequate, supplemental field observations will be made. Implicit in this objective is the desire to show whether or not meaningful evaluations of interbasin groundwater flux can be made using only existing data.

2. Demonstrate the need for more careful evaluation of regional geo$\operatorname{logic}$, hydrologic, and topographic information in the designation of water management districts.

At the present time, collection of data for the purpose of "designating" a groundwater basin in Colorado is limited to the boundaries of the "bedrock" basin under consideration. Assessment of interbasin groundwater transfer can be qualitatively achieved by study of the regional framework of which the basin is only a part.

3. Develop principles and methods for estimation of water transfer at bedrock alluvium contacts.

It is envisioned that several levels of investigation can be available for the assessment of interbasin groundwater flux. A11 
levels of investigation, whether qualitative/reconnaissance or quantitative/detailed need to be founded on the basic principles and laws which describe groundwater motion.

\section{Reports Available}

A list of reports, theses and publications resulting from this work as of 1972 is given below. One additional dissertation will be available by December 1972. It is anticipated that additional publications will be made available in the future. Several portions of this completion report and figures are reproduced from the reports listed below. The authors wish at this time to acknowledge the work of Bibby, Geoke, Scroggs, Spane and Sapik.

Bibby, R., 1969; Flow Between the Confined Aquifer of the Fox Hills Sandstone and the Alluvial Aquifer in the North Kiowa-Bijou District, Colorado; M. S. Thesis, Department of Civil Engineering, Colorado State University.

Bibby, R., 1971; Statistical Error Analysis of Ground Water Systems, Ph. D. Dissertation, Colorado State University.

Bibby, R. and D. K. Sunada, 1971; Mathematical Model of a Leaky Aquifer, Journal of Irrigation and Drainage, ASCE, Vo1. 97, No. IR3.

Bibby, R. and D. K. Sunada, 1971; Statistical Error Analysis of a Numerical Model of Confined Ground Water Flow, International Symposium on Stochastic Hydraulics, Pittsburgh.

Geoke, J. W., 1970; The Hydrogeology of the Black Squirrel Creek Basin, E1 Paso County, Colorado; M. S. Thesis, Department of Geology, Colorado State University, Fort Collins, Colorado.

Scroggs, D. L., 1971; Bedrock Stratigraphy in Black Squirrel Creek Basin, E1 Paso County, Colorado; M. S. Thesis, Department of Geology, Colorado State University, Fort Collins, Colorado.

Spane, F., 1971; Hydrogeologic Studies Near Akron, Colorado; M. S. Thesis, Department of Geology, Colorado State University, Fort Collins, Colorado.

Wa1tz, J. P., 1970; Water Transfer at Bedrock-Alluvium Contacts; Proceedings of Ogallala Aquifer Symposium, Special Report No. 39, Texas Technical University, Lubbock, Texas. 
II. DESCRIPTION OF MATHEMATICAL MODEL

\section{$\underline{\text { Procedure }}$}

Many techniques are presently available for describing ground water flow in aquifers. Of these the numerical models are best suited for analysis of basin wide ground water flow because of their flexibility and speed of analysis.

The mathematical model used in this study was developed by the faculty and graduate students of the Ground Water Section, Civil Engineering Department, Colorado State University. Dr. H. K. van Poolen of Marathon Oil Company and Dr. E. A. Breitenbach, Associate Professor of Civil Engineering, Colorado State University assisted in the development of the mathematical model.

Eshett and Longenbaugh (1965) present the partial differential equation for transient, saturated ground water flow in its implicit central finite difference form. They describe two methods of solution of this equation, including the Gauss Elimination technique which is used in the model. They also outline some modeling procedures. In a later paper, Longenbaugh (1967) describes using the model to simulate part of the Arkansas River aquifer of Colorado.

Bittinger et al. (1967) describe much the same information as Eshett and Longenbaugh and also discuss the use of the model in management decisions.

Description of the Mathematical Model

The non-1inear partial differential equation describing transient, two-dimensional flow in a saturated porous medium may be derived from 
the mass continuity equation and Darcy's Law and written:

$\frac{\partial}{\partial x}\left(K_{x} \cdot h \cdot \Delta y \frac{\partial H}{\partial x}\right) \Delta x+\frac{\partial}{\partial y}\left(K_{y} \cdot h \cdot \Delta x \frac{\partial H}{\partial y}\right) \Delta y=Q+S \Delta x \Delta y \frac{\partial H}{\partial t}$

where,

$$
\begin{aligned}
& \mathrm{K}=\text { hydraulic condictivity. (L/T) } \\
& \mathrm{h}=\text { saturated thickness of aquifer. (L) } \\
& \mathrm{H}=\text { water table elevation above a datum. } \\
& \mathrm{S}=\text { storage coefficient (dimensionless). } \\
& \mathrm{Q}=\text { net groundwater withdrawal. }\left(\mathrm{L}^{3} / \mathrm{T}\right) \\
& \mathrm{x}, \mathrm{y}=\text { space dimensions. (L) } \\
& \mathrm{t}=\text { time dimension. (T) }
\end{aligned}
$$

Being non-linear, equation (1) cannot be solved analytically and numerical techniques must be applied. To obtain a numerical model, equation (1) is written in finite difference form for a particular geometric grid system. Two prominant grid systems are the rectangularly shaped grids and the polygon shaped grids. The advantages and disadvantages to each grid system is discussed in a Texas Technical University report (1970). The selection of a particular grid system is basically a matter of preference and in this study a rectangular grid system is selected.

Using an implicit, central finite difference form for a rectangular grid system, equation (1) becomes,

$$
\begin{aligned}
A^{t} H_{i, j-1}^{t+\Delta t}+B^{t} H_{i, j+1}^{t+\Delta t}+C^{t} H_{i-1, j}^{t+\Delta t} & +D^{t} H_{i+1, j}^{t+\Delta t}-(A+B+C+D+E)^{t} H_{i, j}^{t+\Delta t} \\
& =Q^{t+\Delta t / 2}-E H^{t}
\end{aligned}
$$


where,

$$
\begin{aligned}
& A=\frac{2 K_{i, j} \cdot K_{i, j-1} \cdot \Delta y_{i, j} \cdot \Delta y_{i, j-1} \cdot h_{i, j-1 / 2}}{\Delta y_{i, j} \cdot K_{i, j} \Delta x_{i, j-1}+\Delta y_{i, j-1} \cdot K_{i, j-1} \Delta x_{i, j}} \\
& B=\frac{2 K_{i, j} \cdot K_{i, j+1} \cdot \Delta y_{i, j} \cdot \Delta y_{i, j+1} \cdot h_{i, j+1 / 2}}{\Delta x_{i, j} \cdot K_{i, j+1} \cdot \Delta y_{i, j+1}+\Delta x_{i, j+1} \cdot K_{i, j} \cdot \Delta y_{i, j}} \\
& C=\frac{2 K_{i, j} \cdot K_{i-1, j} \cdot \Delta x_{i, j} \cdot \Delta x_{i-1, j} \cdot h_{i-1 / 2, j}}{\Delta y_{i, j} \cdot K_{i-1, j} \cdot \Delta x_{i-1, j}+\Delta y_{i-1, j} \cdot K_{i, j} \cdot \Delta x_{i, j}} \\
& D=\frac{2 K_{i, j} \cdot K_{i+1, j} \cdot \Delta x_{i, j} \cdot \Delta x_{i+1, j} \cdot h_{i+1 / 2, j}}{\Delta y_{i, j} \cdot K_{i+1, j} \cdot \Delta x_{i+1, j}+\Delta y_{i+1, j} \cdot K_{i, j} \cdot \Delta x_{i, j}} \\
& E=\frac{S_{i, j} \cdot \Delta x_{i, j} \cdot \Delta y_{i, j}}{\Delta t}
\end{aligned}
$$

The term $\left(h_{i, j-1 / 2}\right)$ in the coefficient $A$ and its counterpart in each of the other coefficients is the effective saturated thickness between the grids $\left(h_{i, j-1}\right)$ and $\left(h_{i, j}\right)$. It is computed from:

$$
h_{i, j-1 / 2}=\operatorname{Max}\left(H_{i, j}, H_{i, j-1}\right)-\operatorname{Max}\left(z_{i, j}, z_{i, j-1}\right)
$$

where $\quad Z$ = bedrock elevation above a datum.

The $i, j$ notation (see figure 2) refers to the grid point for which a particular equation is written and the superscripts represent the time level of computation.

The coefficients A, B , C , D are held constant, for each time increment, at the value they have at the beginning of the increment. This approximation effectively linearizes the difference equation. The ground water withdrawal, Q , is held constant throughout each increment at the value it has at the middle of the increment. 


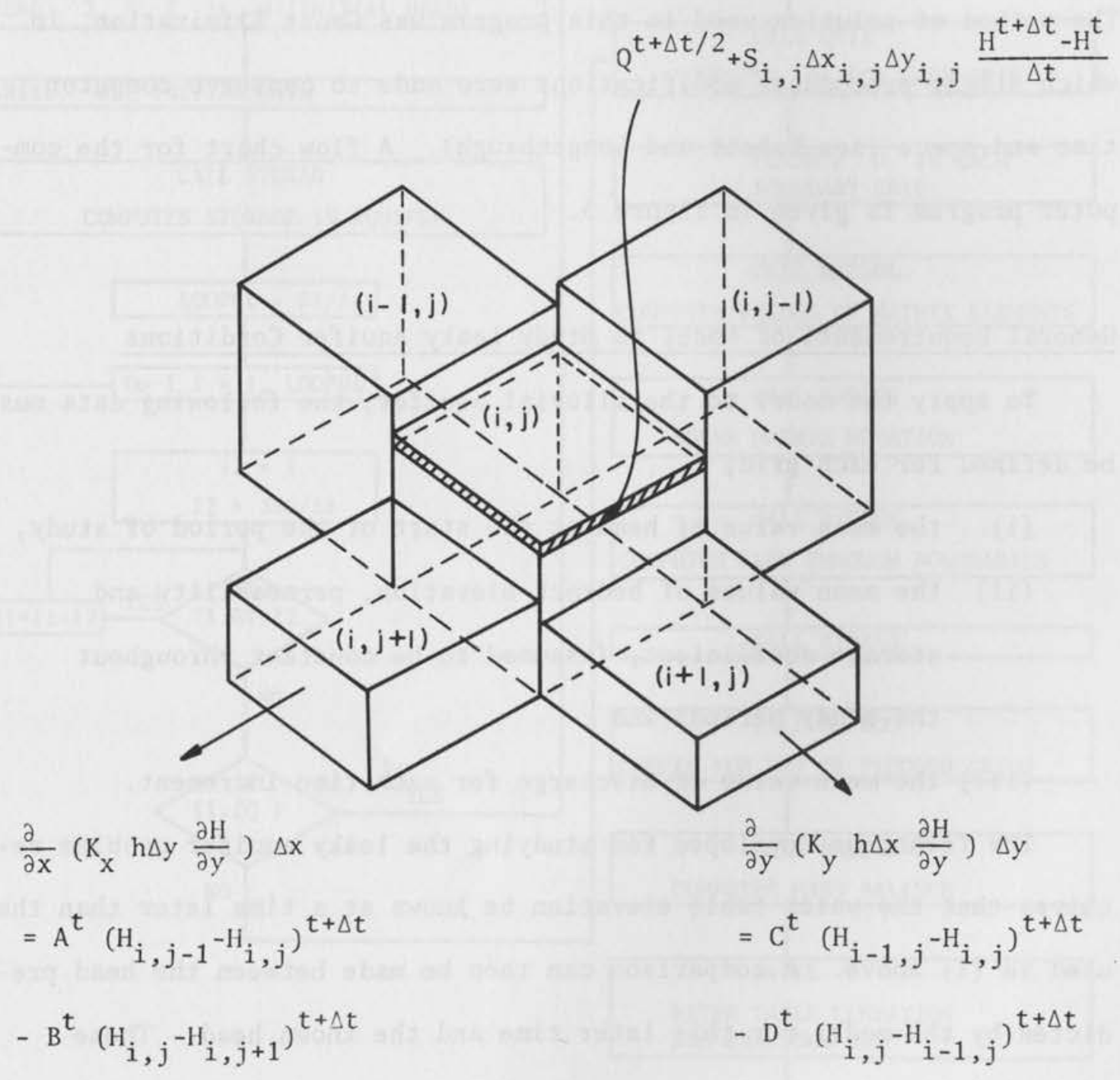

Figure 2. Finite difference grid and its physical significance. 
Equation (2) is written for each grid for a particular time step and the entire system of equations thus obtained is solved simultaneously. The solution will be the predicted value of $\mathrm{H}$, the water table elevation, for the end of the time step. This predicted value will be used as the initial value for the next time step and the entire process repeated. The method of solution used in this program was Gauss Elimination, in which slight procedural modifications were made to conserve computer time and space (see Eshett and Longenbaugh). A flow chart for the computer program is given in figure 3 .

General Requirements of Model to Study Leaky Aquifer Conditions

To apply the model to the alluvial aquifer, the following data must be defined for each grid;

(i) the mean value of head at the start of the period of study,

(ii) the mean values of bedrock elevation, permeability and storage coefficient, (assumed to be constant throughout the study period) and

(iii) the mean value of discharge for each time increment.

The technique developed for studying the leaky aquifer problem requires that the water table elevation be known at a time later than that used in (i) above. A comparison can then be made between the head predicted by the model for this later time and the known head. These predicted values were then compared to the known water table elevations. Assuming that the model and the input data are accurate, a discrepancy, occurring between the known and predicted water table elevations, indicates that some hydrologic factor influencing the flow of water in the alluvial aquifer has not been taken into account in the model. If the 


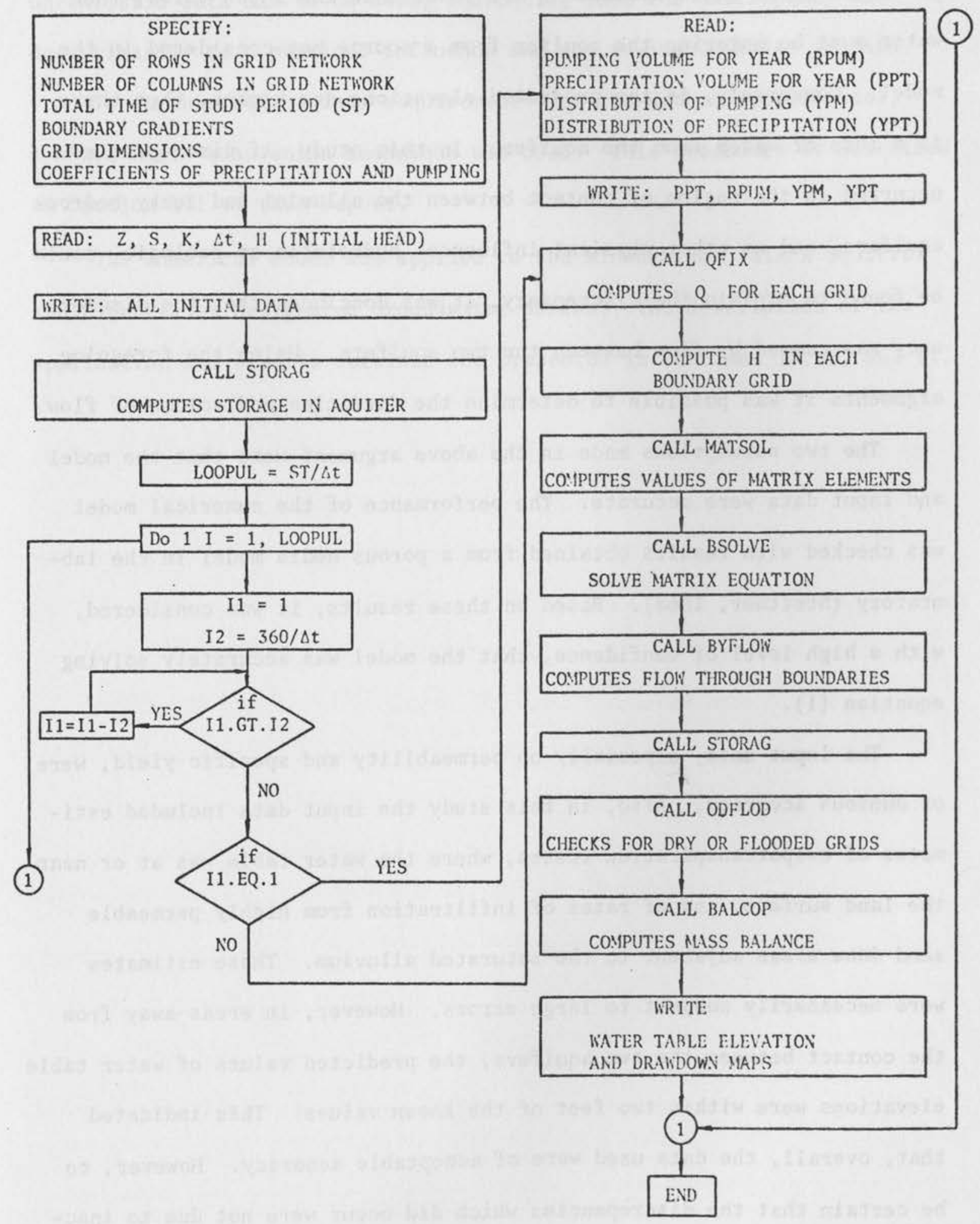

Figure 3. Flow chart. 
predicted water table elevations are lower than the known value, then water must be entering the aquifer from a source not considered in the mode1. Conversely, if the predicted elevations are higher, then there is a loss of water from the aquifer. In this study, if discrepancies occurred in the region of contact between the alluvial and leaky bedrock aquifers, and no other physical influence, hydrologic or geologic, could be found to explain the discrepancy, it was concluded that the discrepancy was caused by flow between the two aquifers. Using the foregoing arguments it was possible to determine the direction and volume of flow. The two assumptions made in the above argument were that the model and input data were accurate. The performance of the numerical model was checked with results obtained from a porous media model in the laboratory (Stettner, 1968). Based on these results, it was considered, with a high level of confidence, that the model was accurately solving equation (1).

The input data, especially on permeability and specific yield, were of dubious accuracy. Also, in this study the input data included estimates of evapotranspiration losses, where the water table was at or near the land surface, and of rates of infiltration from highly permeable sand dune areas adjacent to the saturated alluvium. These estimates were necessarily subject to large errors. However, in areas away from the contact between the two aquifers, the predicted values of water table elevations were within two feet of the known values. This indicated that, overall, the data used were of acceptable accuracy. However, to be certain that the discrepancies which did occur were not due to inacurate data, the values of transmissability and storage coefficient were adjusted so that the discrepancies were eliminated. To do this, totally 
13

unrealistic data had to be used, indicating that the discrepancy was due primarily to a physical influence and not to inaccuracies in data.

To further define data requirements for the deterministic model, a Monte Carlo simulation technique was used. This procedure is described in Section III of this report.

The numerical model was applied to the Kiowa-Bijou, Black Squirrel and High Plains Designated Groundwater Basins. The description of the application and results obtained are presented in Sections IV, V, and VI. 


\section{APPLICATION OF NUMERICAL MODEL - STATISTICAL ANALYSIS}

\section{OF DATA REQUIREMENTS}

A method is presented here which, by considering the input variables to a numerical model of flow in aquifers as random variables, enables the accuracy of these input variables to be related to the accuracy of the output. The input variables considered are initial head, permeability, discharge, storage coefficient, and saturated thickness and the output variable is head after a period of time. The method involves the use of the Monte Carlo technique to generate a random sample of the final head, the computation of a tolerance limit width on the final head which is used as a measure of its accuracy, and a regression analysis to determine a predictive relation between the accuracy of the input variables and the computed tolerance limit width. The results indicate that if only one of the input variables contains error then this error is linearly related to the error in final head. If all the input variables contain error then only the error on initial head is significant in predicting the error in final head and the predictive relation is linear.

In addition, a method of estimating the parameters of the probability density functions of the input variables from available field data is described and the relation is determined between the accuracy of these estimates and the number of data points used to make the estimate.

A numerical model, obtained by approximating the partial differential equation of flow in porous media by finite differences, is commonly used to analyze groundwater basins. This deterministic model is frequently used in situations in which nothing is known of the accuracy of the input data to the model or how errors in the input data are related to the accuracy of the results. A method will be described which, by considering 
the parameters of the model as random variables, enables the accuracy of the results to be related to the accuracy of the input data. The method also provides a means of estimating, from field data, the parameters of the density functions of the input variables to the model. The accuracy of these estimates is related to the amount of data used.

Numerical Mode1

The numerical model used in this study has been described in Section II. In modeling a confined aquifer, the region of flow is divided up into grids, and the input variables to the model are the mean values in each grid of $h_{I}$, the initial head, $K$, the permeability, $b$, the saturated thickness, Q, the discharge, S, the storage coefficient. The output from the model is the mean value in each grid of the final head, $\mathrm{H}_{\mathrm{F}}$, after a period of time. This study shows how the parameters of the density functions of the above input variables can be estimated from available field data, how the accuracy of these estimates is related to the amount of data used and how the accuracy of these input variables is related to the accuracy of the final head, $\mathrm{H}_{\mathrm{F}}$.

\section{Theoretical Framework}

It is assumed that each of the input variables has a unique nonrandom value at every point in the aquifer, and that associated with each observation of these variables is a random measurement error. For example, an observation of permeability will be:

$$
k_{i}=k_{i}+e_{i} \quad, \quad i=1 \ldots n,
$$


where,

$$
\begin{aligned}
& k_{i}=\text { observed value of permeability (random and known). } \\
& K_{i}=\text { true value of permeability (non-random and unknown) } . \\
& e_{i}=\text { measurement error (random and unknown) } . \\
& n=\text { number of observations. }
\end{aligned}
$$

The error, $e_{i}$, will be considered to be independent of $K_{i}$ and to be normally distributed, that is:

$$
e_{i} \sim N\left(0, \sigma_{K}^{2}\right) \quad, \quad i=1 \ldots n,
$$

so that,

$$
k_{i} \sim N\left(K_{i}, \sigma_{K}^{2}\right) \quad, \quad i=1 \ldots n \quad .
$$

For purely random measurement errors the normal distribution of the variable $k_{i}$ can be justified by Lyapunov's limit theorm (Shchigolev).

Each input variable is assumed to be expressable as a function of the space coordinates by an equation of the form:

$$
\mathrm{K}=\alpha_{0}+\alpha_{1} \mathrm{X}_{1}+\ldots+\alpha_{\mathrm{N}} \mathrm{X}_{\mathrm{N}},
$$

where,

$$
\begin{aligned}
& \alpha_{i}=\text { constant coefficient (unknown) } \\
& x_{i}=x_{i}(x, y) \quad \text {, where } x, y \text { are space coordinates, }
\end{aligned}
$$

so that,

$$
k_{i}=\alpha_{0}+\alpha_{1} x_{1 i}+\ldots .+\alpha_{N} x_{N i}+e_{i}, \quad i=1 \ldots n,
$$

or, in matrix notation,

$$
\underline{k}=\underline{\alpha}^{\prime} \underline{x}+\underline{e}
$$

The variables $x_{j i}, j=1 \ldots N, i=1 \ldots n$, will be considered to be observed without error, so that equation (7) fits the normal theory of the General Linear Hypothesis Model of Ful1 Rank, Mode1 I, Case A 
(Graybil1, 1961). Using this theory, maximum likelihood estimates can be found for $\alpha_{i}, i=1 \ldots N$ and $\sigma_{K}^{2}$. If these estimates are designated $\underline{Q}$ and $\hat{\theta}_{\mathrm{K}}^{2}$ (Graybill), they are given by

$$
\underline{\hat{\alpha}}=\left(\underline{X}^{\prime} \underline{X}\right)^{-1} \underline{X}^{\prime} \underline{k}
$$

where,

$$
\underline{\alpha} \sim N\left[\underline{Q}, \hat{\partial}_{K}^{2}\left(\underline{X}^{\prime} \underline{X}\right)^{-1}\right]
$$

and,

$$
\partial_{K}^{2}=\frac{\underline{k}^{\prime} \underline{k}-\underline{Q}^{\prime} \underline{X}^{\prime} \underline{k}}{(n-N)}
$$

where,

$$
(n-N) \frac{\partial_{K}^{2}}{\partial_{K}^{2}} \sim x^{2}(n-N)
$$

The input to the numerical model is the mean value of each variable in each grid. For permeability, the true mean value of permeability in a grid, $\overline{\mathrm{K}}$, will be given by:

$$
\bar{K}=\frac{1}{\Delta x \Delta y} \quad \begin{array}{lll}
x+\Delta x & y+\Delta y \\
x & y
\end{array} \quad\left(\alpha_{0}+\alpha_{1} x_{1}+\ldots+\alpha_{N} x_{N}\right) d x d y,
$$

where, the grid has coordinates $(x, y)(x, y+\Delta y),(x+\Delta x, y),(x+\Delta x, y+\Delta y)$. The estimate of $\bar{K}$ will be taken to be:

$$
\tilde{\bar{K}}=\frac{1}{\Delta x \Delta y} \quad \begin{array}{lll}
x+\Delta x & y+\Delta y \\
x & y
\end{array} \quad,
$$

and is such that,

$$
\tilde{\mathrm{K}} \sim \mathrm{N}\left(\overline{\mathrm{K}}, \rho_{\mathrm{K}}^{2}\right) \quad \text {. }
$$


The standard deviation $\rho_{K}$ will be taken as the measure of error in the estimate, $\tilde{\overline{\mathrm{K}}}$, of $\overline{\mathrm{K}}$. It can be shown that:

$$
\rho_{K}=\frac{\sigma_{k}}{\sqrt{n}} f\left(X_{j i}\right) \quad, \quad j=1 \ldots N \quad, \quad i=1 \ldots n,
$$

where,

$$
f\left(x_{j i}\right)=a \text { function of } x_{j i}, j=1 \ldots N, i=1 \ldots n .
$$

The estimate of ${ }^{\rho_{K}}$ will then be $\tilde{\rho}_{K}$, where,

$$
\tilde{\rho}_{K}=\frac{\hat{\sigma}_{K}}{\sqrt{n}} f\left(X_{j i}\right) \quad, \quad j=1 \ldots N \quad, \quad i=1 \ldots n \text {. }
$$

Equations analogous to equation (11) for each of the input variables provide a method of estimating the mean value of each of the input variables in every grid from available observations. The accuracy of these estimates is given by equations analogous to equation (13) and is inversely proportional to the square root of the number of observations used to make the estimate. Since the measures of error of the input variables, $\tilde{\rho}_{\mathrm{K}}, \tilde{\rho}_{\mathrm{b}}, \tilde{\rho}_{\mathrm{h}_{\mathrm{I}}}, \tilde{\rho}_{\mathrm{Q}}, \tilde{\rho}_{\mathrm{S}}$, cannot be analytically related to the accuracy of the final head, the following procedure was adopted.

\section{Experimental Procedure}

The error relations were determined first of all between each input variable, considered singly, and the output and secondly between the input variables, considered simultaneously, and the output. The procedure was basically the same in both cases, and is described below for the case when only permeability is considered to contain error. It consists of 1) the application of the Monte Carlo technique to generate a random 
sample from the density of $\mathrm{H}_{\mathrm{F}}, 2$ ) the computation of a tolerance limit to be used as a measure of error in $\mathrm{H}_{\mathrm{F}}$, and 3) the use of regression analysis to predict the error of $\mathrm{H}_{\mathrm{F}}$ from the error in permeability. STEP 1

A randomly generated value of $\tilde{\bar{K}}$ and $\tilde{\rho}_{\mathrm{K}}$ is assigned to each grid. The other variables are assigned random mean values and zero variances. STEP 2

In every grid a random value of permeability is generated from its distribution, which is assumed to be normal.

STEP 3

With these random values of permeability and the fixed values of the other input variables, the numerical model is used to solve for the head after a specified time has elapsed.

STEP 4

Repeat STEPS 2 and 3 until a random sample of size $M$ of values of head in every grid is generated, that is, $\left(\mathrm{H}_{\mathrm{F}}\right)_{i}, i=1 \ldots \mathrm{M}$. STEP 5

In every grid determine the tolerance limits on $\mathrm{H}_{\mathrm{F}}$ and the width of the tolerance limit, $t$. The determination of a tolerance limit for a random variable, $\mathrm{X}$, requires that an ordered sample be available from its density function, $f_{x}(x)$. A tolerance limit is defined to be:

$$
P\left[\int_{L_{1}(\underline{x})}^{L_{2}(\underline{x})} f_{x}(x) d x>\beta\right]=1-\alpha,
$$

where, $L_{1}(\underline{x}), L_{2}(\underline{x})$ are functions of the random sample, $\underline{x}=x_{1} \ldots x_{M}$, from $f_{x}(x)$. For a more detailed development see any standard text on non-parametric statistics. 
STEP 6

Randomly generate a new value of $\tilde{\rho}_{K}$ in every grid and repeat STEPS $2,3,4$, and 5 until a sample, $m$, of tolerance limit widths, $t$, in each grid is obtained. Each width will correspond to a value of $\tilde{\rho}_{\mathrm{K}}$. STEP 7

Using the theory of the Regression Model (Mode1 III, Case 2) (Graybil1, 1961) find a predictive relation between $t$ and $\tilde{\rho}_{\mathrm{K}}$.

To use the theory of the Regression Model it is necessary to assume that the joint density of $t$ and $\tilde{\rho}_{K}$ is given by:

$$
f\left(t, \tilde{\rho}_{K}\right)=h\left(\tilde{\rho}_{K}\right) \frac{1}{\sqrt{2 \pi}} \cdot \frac{1}{\sigma_{t^{\prime}}} \exp -\frac{1}{2} \frac{t-G\left(\tilde{\rho}_{K^{\prime}}\right)^{2}}{\sigma_{t^{\prime}}}
$$

where, $G\left(\tilde{\rho}_{K}\right)$ is a function of $\tilde{\rho}_{K}$ which is linear, in the coefficients. In this study it was taken to be a polynomial, so that, $G\left(\tilde{\rho}_{K}\right)=\sum \alpha_{i=0}\left(\tilde{p}_{K}\right)^{i}$.

$h\left(\tilde{p}_{K}\right)$ is the marginal density of $\tilde{\rho}_{K}$ and does not contain $\alpha_{i}$, $i=1 \ldots N$ or $\tilde{p}_{t}$, . From equation (15) it follows that the conditional distribution of $t$ given $\tilde{\rho}_{K}=\tilde{\rho}_{K}^{*}$ is, $f\left(t^{\prime}\right)$, where,

$$
f\left(t^{\prime}\right)=f\left(t / \tilde{\rho}_{K}=\tilde{\rho}_{K}^{*}\right)=\frac{1}{\sqrt{2 \pi}} \cdot \frac{1}{\sigma_{t^{\prime}}} \cdot \exp -\frac{1}{2} \frac{t-\sum_{i=0} \alpha_{i}\left(\tilde{\rho}_{K}\right)^{i}{ }^{\sigma^{\prime}}}{\sigma_{t^{\prime}}}
$$

so that,

$$
E\left(t^{\prime}\right)=E\left(t / \tilde{\rho}_{K}=\tilde{\rho}_{K}^{*}\right)=\sum_{i=0}^{N} \alpha_{i}\left(\tilde{\rho}_{K}^{*}\right)^{i}
$$

The coefficients $\alpha_{i}, i=1 \ldots N$ can now be estimated and the value of $\mathrm{N}$ determined such that the "best" predictive relation between $\mathrm{E}\left(\mathrm{t}^{\prime}\right)$ and $\tilde{\rho}_{\mathrm{K}}^{*}$ is obtained. This is done by estimating the coefficients for $\mathrm{N}=1,2$ and 3 . For each of the three polynomials the F-statistic was 
computed to test the hypothesis that each of the coefficients was zero and so determine the "best" polynomial.

The data generated in the above procedure was also used to estimate the coefficient of variation, $C$, of $h_{F}$ by,

$$
C_{F}=\frac{\frac{1}{M-1} \sum_{i=1}^{M}(F)_{i}-\mu}{\mu_{F}} F \quad \mu_{F}^{2}=\frac{1}{M} \sum_{i=1}^{M}(F)_{i}
$$

and a predictive relation was established between it and the coefficient of variation of the input variable,

$$
C_{K}=\frac{\tilde{\rho}_{K}}{\tilde{\tilde{K}}},
$$

in exactly the same way as the one described above.

Having considered the input variables individually the next step was to consider them simultaneously. This was done using procedures exactly analogous to those described above.

A detailed analysis of the error relationships has been presented by Bibby (1969) and Bibby and Sunada (1971). Consequently only the most significant results are presented here.

In using a numerical model to study groundwater aquifers the results of this study clearly indicate that when there is an error in only one input variable, that this error is linearly related to the error in output. For error in initial head, this relation is approximately one-toone for short time periods, but for the other input variables the error on output is one or two orders of magnitude less than the input error.

When errors occur in all the input variables only the error on initial head is significant in predicting the error on final head. The other 
input errors are comparatively non-significant. This relation is linear, and for short periods of time approximately one-to-one, but with increasing time, the output error becomes less dependent on the input error. This, together with the increase in the value of the constant coefficient in the regression equation and the decrease in the sum of squares of deviations from the regression line, indicates that with increasing time the error on output tends toward a constant value.

The relation between the input and output errors which have been obtained when combined with the result given in equation (7), relating the input error to the number of data points used to estimate the input variable, provide a means of deciding on which variables it is most beneficial to collect data and how much data is required. 


\section{APPLICATION OF NUMERICAL MODEL - KIOINA-BIJOU BASIN}

The mathematical model was applied in the Kiowa-Bijou and Black Squirrel ground water basins of Colorado. It has been considered for some time that there is movement of ground water between the saturated alluvium of the two hasins and the Fox Hills Sandstone beneath the alluvium. The relative locations of the two basins are shown in figure 4 . These basins were thought to be isolated from each other in terms of exchange of either ground water or surface water. However, the two basins are interconnected by the Fox Hills Sandstone which is in direct contact with the water bearing alluvium. Figure 5 is a cross-section which schematically shows the relation between the Black Squirrel alluvium, Fox Hills Sandstone and the Kiowa-Bijou alluvium. The prime objective of this study was to determine if any significant amounts of water flow between the Fox Hills Sandstone and the alluvium of both basins. In addition it was hoped to determine the direction in which flow occurred, to define the areas in which it occurred, and to estimate the volumes of water involved in the exchange between the two basins. The application of the model is described first for the Kiowa Bijou Basin in Section IV and second for the Black Squirrel Basin in Section V.

\section{Location and Description of the Kiowa-Bijou Basin}

The Kiowa and Bijou Creeks are ephemeral streams which run northward from the Black Forest area of Colorado for over 100 miles, to enter the South Platte River in the vicinity of Fort Morgan. This study was concerned only with the northern part of the basin, since it is in this part that the Fow Hills Sandstone and the saturated alluvium are contiguous. 


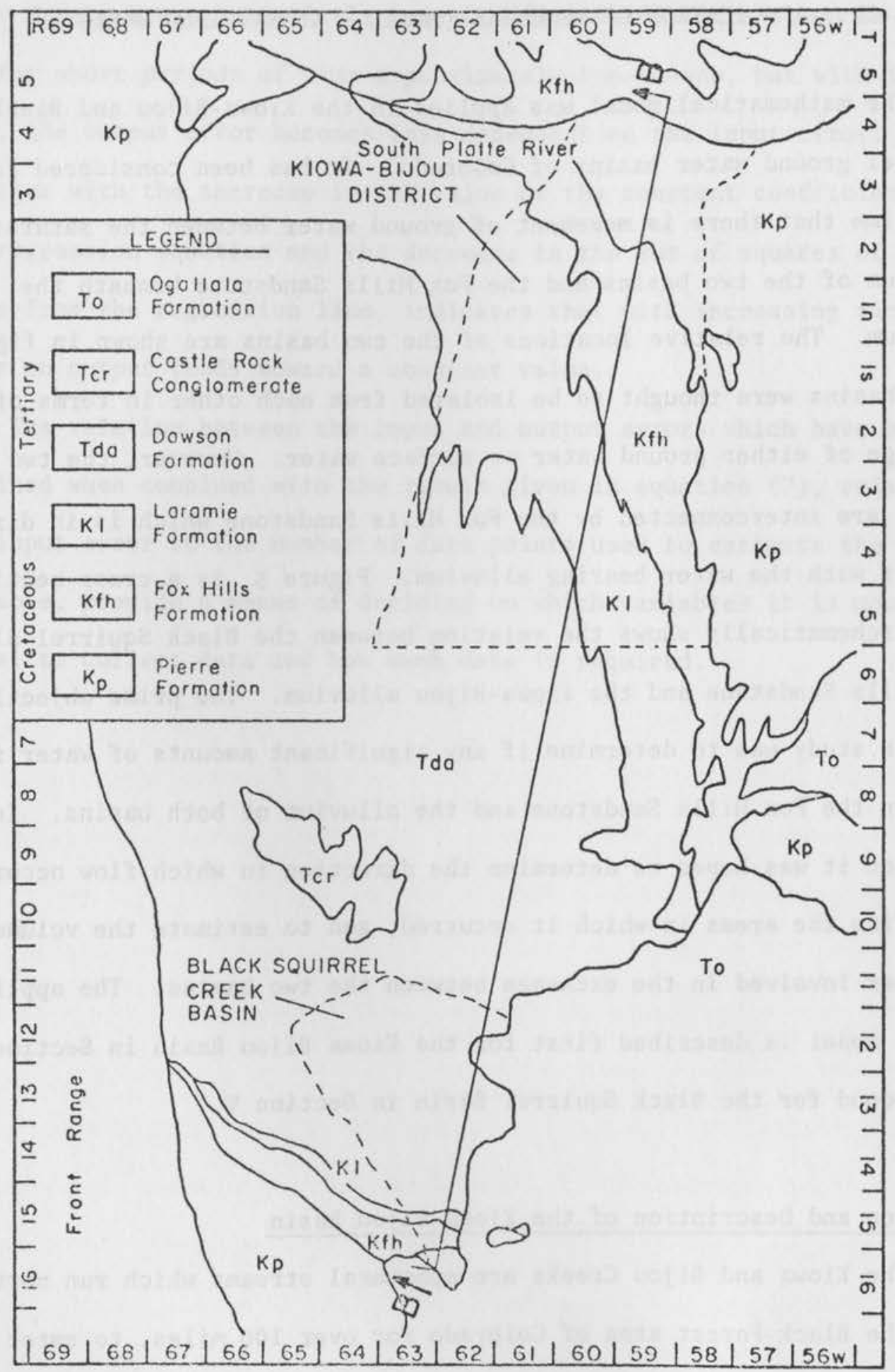

Figure 4. Geologic map of the Denver Basin. Line B-B' indicates cross section between Black Squirrel and Kiowa-Bijou areas. Adapted from Kuhn, 1968. 


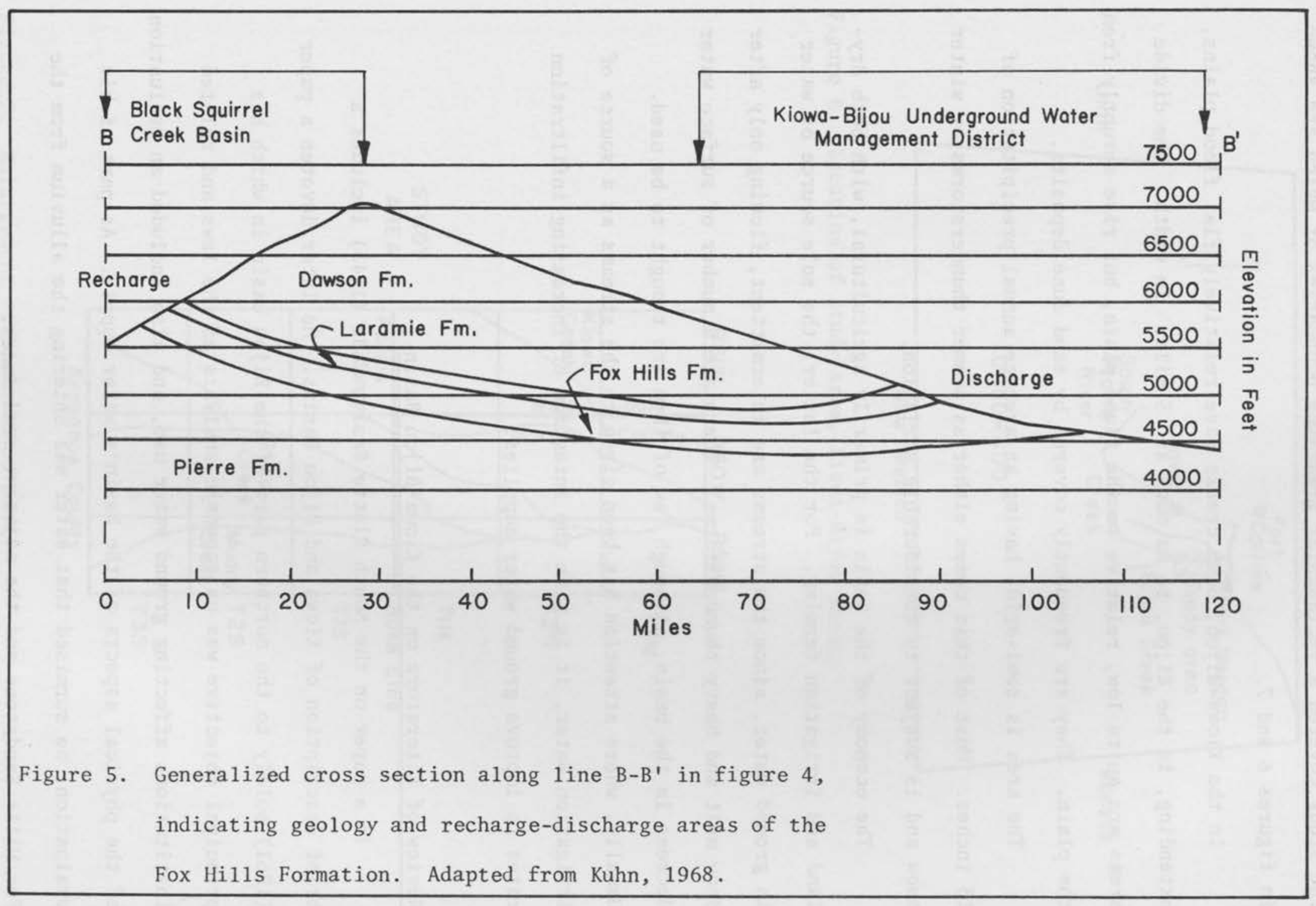


The study covered a rectangular area, the boundaries of which are shown in figures 6 and 7 .

In the Kiowa-Bijou, both creeks have relatively flat flood plains, extending, in the Bijou, to as much as 5 miles in width. The divide areas are quite low, relative to the flood plain, but rise abruptly from the plain. They are frequently covered by sand dune deposits.

The area is semi-arid, having an average annual precipitation of 13 inches. Most of this comes either as summer thunderstorms or winter snow and is subject to considerable variation.

The economy of the basin is primarily agricultural, with both dryland and irrigation farming. For the latter, the sole source of water is ground water, since the streams are intermittent, flowing only after snow melt and heavy thunderstorms. There are a number of surface water decrees in the basin, although few of them are thought to be used. Usually, where attention has been given to the streams as a source of irrigation water, it is with the intention of increasing infiltration rates to improve ground water supplies.

Review of Literature on the Kiowa-Bijou Basin

In a paper on the South Platte Basin, Code (1943) includes a brief description of Kiowa and Bijou Basins. He later devotes a paper (1961) solely to the northern part of the Bijou basin in which his principal objective was an economic analysis of the laws and related institutions affecting ground water use, and also included an evaluation of the physical aspects of the basin's water supply. As part of his evaluation, he surmised that water was entering the alluvium from the Fox Hills Sandstone and the adjacent sand dunes. 


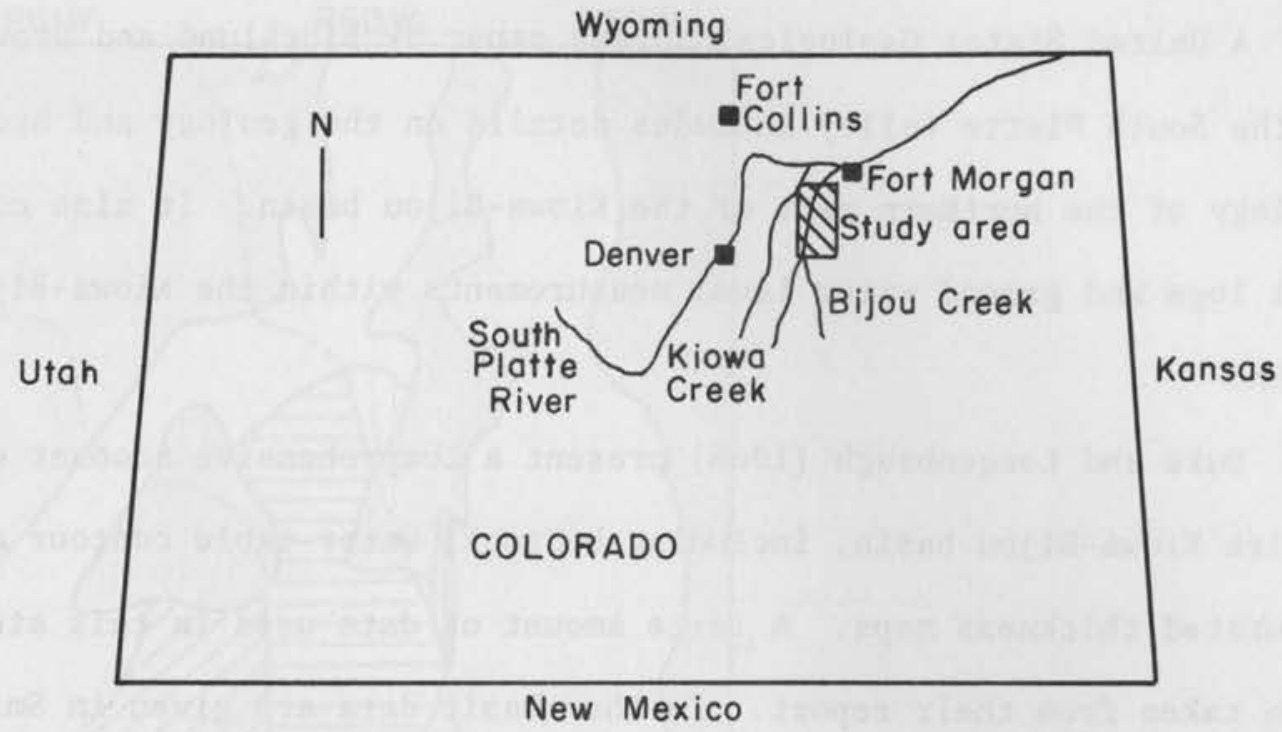

Figure 6. Location of study area, Kiowa-Bijou Basin.

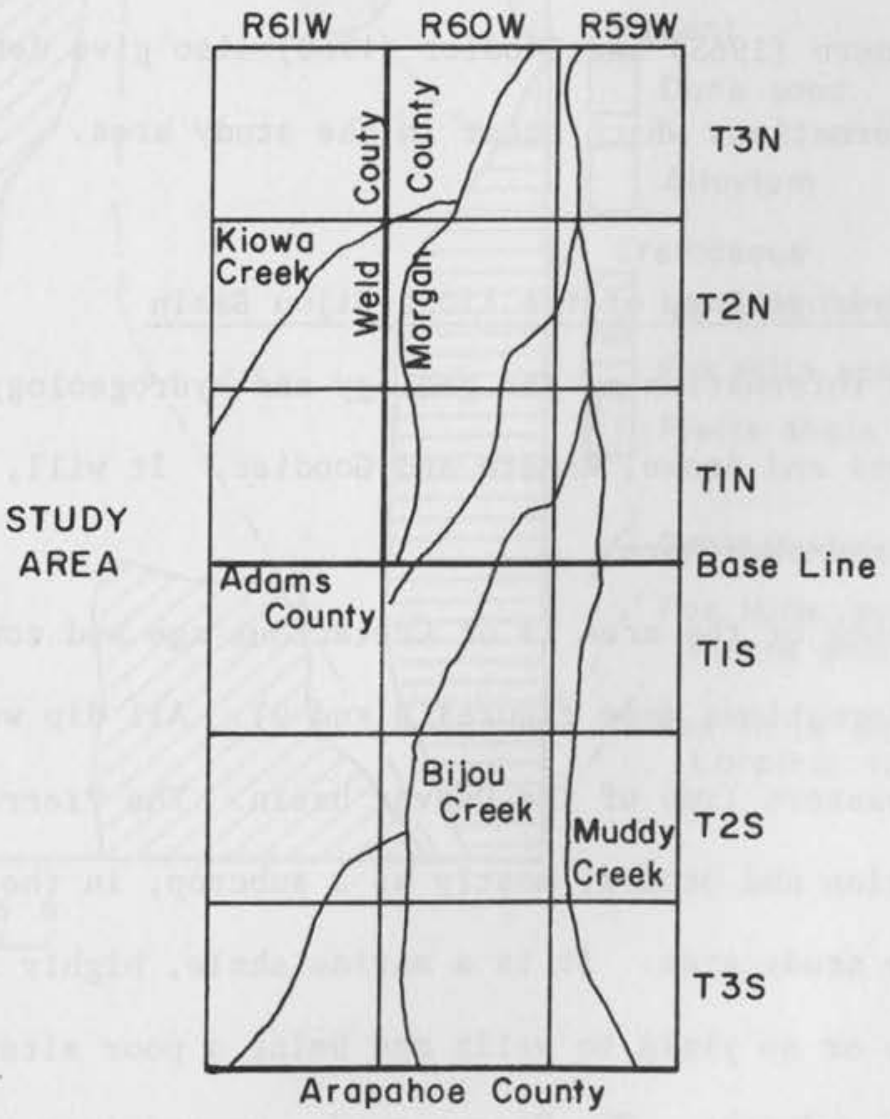

Figure 7. Enlargement of Kiowa-Bijou Basin. 
A United States Geological Survey paper by Bjorklund and Brown (1957) on the South Platte Valley includes details on the geology and hydrogeology of the northern part of the Kiowa-Bijou basin. It also contains wel1 logs and ground water level measurements within the Kiowa-Bijou basin.

Duke and Longenbaugh (1966) present a comprehensive account of the entire Kiowa-Bijou basin, including bedrock, water-table contour and saturated thickness maps. A large amount of data used in this study has been taken from their report. Further basic data are given in Smith and Schulz (1962) and McConaghy and Colburn (1964).

A thesis by Kuhn (1968) gives a detailed account of the geology of the Fox Hills Sandstone and deals with its hydraulic connection with the alluvium. Romero (1965) and Goodier (1960) also give detailed accounts of geologic formations which occur in the study area.

Geology and Hydrogeology of the Kiowa-Bijou Basin

Detailed information of the geology and hydrogeology is given in Kuhn, Bjorklund and Brown, Romero and Goodier. It will, therefore, be only briefly reviewed here.

The bedrock of the area is of Cretaceous age and consists of three conformable formations (see figures 8 and 9). Al1 dip westward, being part of the eastern limb of the Denver basin. The Pierre Shale is the oldest formation and occurs, mostly as a subcrop, in the North-East corner of the study area. It is a marine shale, highly impermeable, having little or no yield to wells and being a poor site of recharge to underlying groundwater. The Pierre grades upward into the Fox Hills 


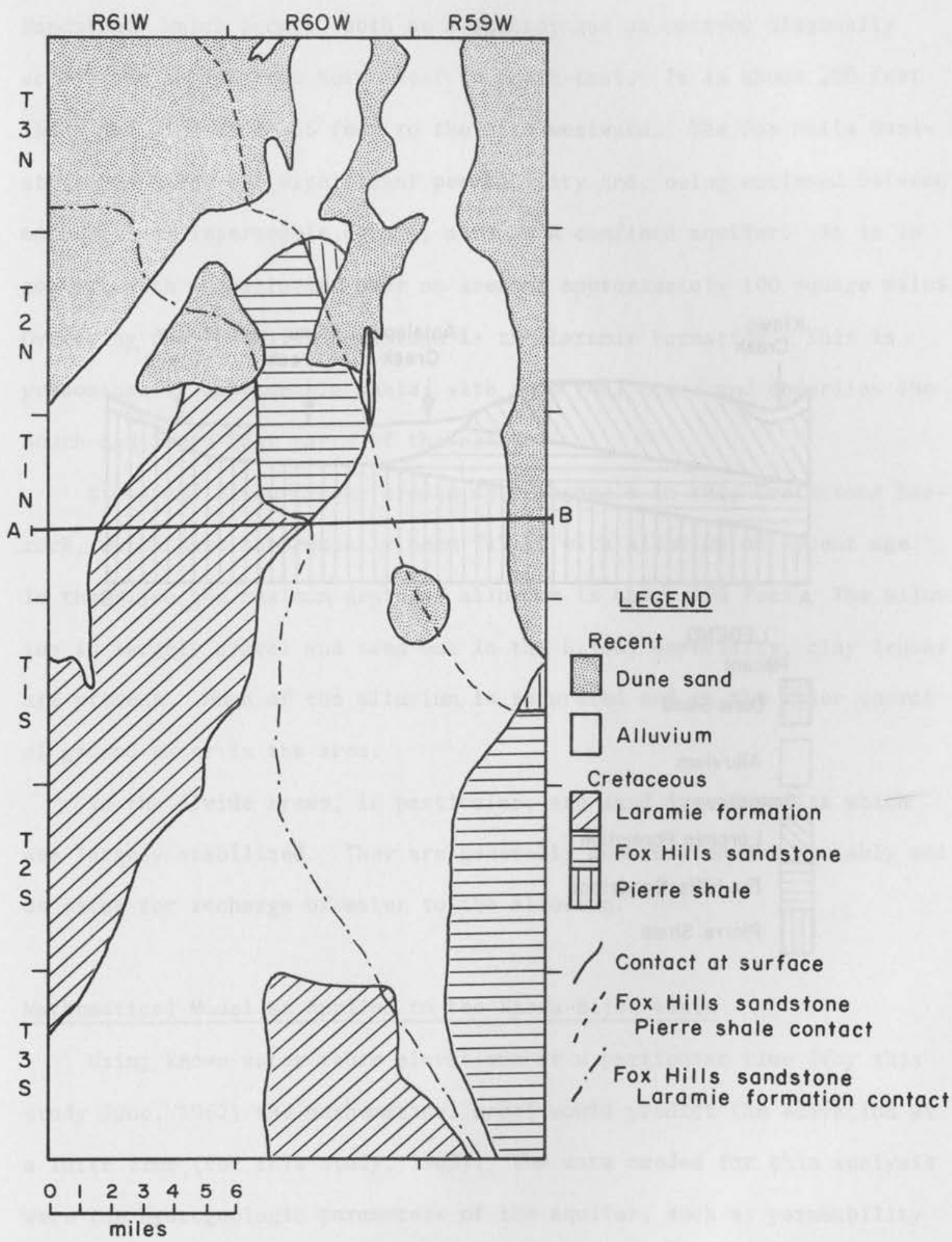

Figure 8. Surface geology of Kiowa-Bijou Basin. 


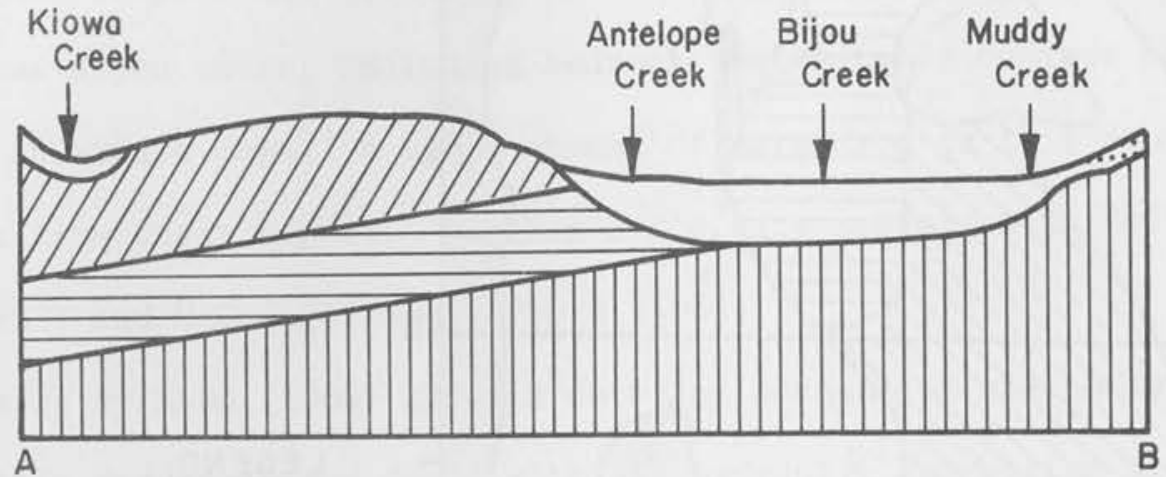

LEGEND

Recent

Dune Sand

Alluvium

Cretaceous

Daramie Formation

Fox Hills Sandstone

Pierre Shale

Figure 9. Diagrammatic vertical section A-B, from figure 8 . 
Sandstone which occurs both as a subcrop and an outcrop diagonally across the region from North-West to South-East. It is about 200 feet thick and dips at 30-35 feet to the mile westward. The Fox Hills Sandstone has a low but significant permeability and, being enclosed between more or less impermeable strata, acts as a confined aquifer. It is in contact with the alluvium over an area of approximately 100 square miles. Overlying the Fox Hills Sandstone is the Laramie Formation. This is predominantly impermeable shale, with some coal beds, and underlies the South and South-East parts of the area.

Kiowa and Bijou Creeks eroded deep channels in this Cretaceous bedrock, which have subsequently been filled with alluvium of Recent age. In the Bijou the maximum depth of alluvium is about 190 feet. The alluvium is largely gravel and sand but in the Bijou, especially, clay lenses are present. Much of the alluvium is saturated and is the major source of ground water in the area.

In the divide areas, in particular, are sand dune deposits which are largely stabilized. They are generally unsaturated but probably act as sites for recharge of water to the alluvium.

Mathematical Model as Applied to the Kiowa-Bijou Basin

Using known water table elevations at a particular time (for this study June, 1962) the mathematical model would predict the elevation at a later time (for this study, 1965). The data needed for this analysis were the hydrogeologic parameters of the aquifer, such as permeability and specific yield, together with the rates of recharge and discharge to the aquifer, such as from precipitation and pumping. 
The area was represented by a system of grids and all the above mentioned factors affecting the flow of water were determined for each grid. In theory, the smaller the grid size used the greater the accuracy obtained. However, within the limits of acceptable accuracy, the grid size is determined by the amount and accuracy of data available, the size of the aquifer under investigation and the amount of computer storage available. For this study the computer could handle about 290 grids, and this, combined with the size of the area to be studied, determined the grid size to be used. A mode1 of 288 rectangular grids $(18 \times 16)$, each two miles by one mile, was used. The model covered a rectangular area of 576 square miles (see figure 10). This was considered a small enough grid size to give quite accurate results, since, in grids which were not influenced by flow between the Fox Hills Sandstone and the alluvium, there was a good correlation between the predicted water table elevation of the model and the actual elevation. It is appreciated that this is not conclusive proof of accuracy. However, if the space dimensions were too large, such a correlation could only have occurred if the error resulting from the modeling of the aquifer by the flow equation was equal and opposite to the error resulting from obtaining a solution to the flow equation by numerical techniques. The probability of the latter occurring is considered to be fairly small. The grids were chosen to coincide with section boundaries, so that each grid consisted of two sections.

In going from the initial known water table elevation to the predicted elevation, the model progressed by a series of time increments. In this study, 36 time increments, each of 30 days, were used, to give a total study period of three years. Much of the data for this study was most 


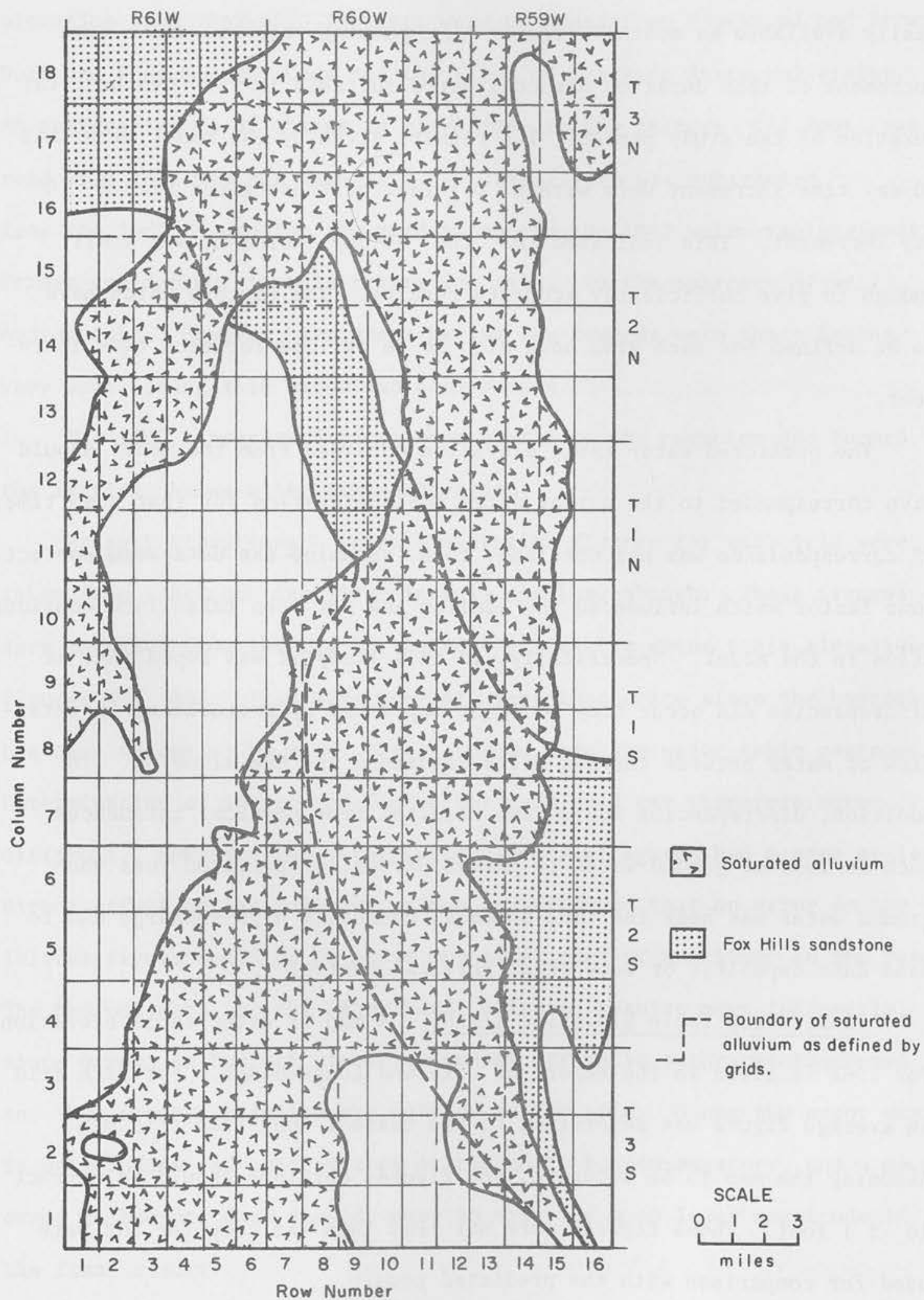

Figure 10. Grid overlaying Fox Hills sandstone and saturated alluvium. 
easily available as monthly figures (e.g.,pumping volumes) and a time increment of this duration was considered suitable in view of the total duration of the study period. The results given by the model with this 30 day time increment were within 0.1 feet of those given with a 10 day increment. This indicated that the 30 day increment was sma11 enough to give sufficiently accurate results. The factors which have to be defined for each grid have also to be defined for each time increment.

The predicted water table elevation obtained from the model should have corresponded to the actual water table elevation for that same time. If correspondence was not obtained, then, assuming the data were correct, some factor which influenced the aquifer had not been taken into consider ation in the model. Specifically, in this study it was hoped that if discrepancies did occur they could be explained by postulating an interflow of water between the Fox Hills Sandstone and the alluvium. In addition, discrepancies could have resulted from physical influences such as loss of ground water to phreatophytes, evaporation loss when ground water was near the land surface, unusually high recharge due to sand dune deposits, or some other physical control.

Final Water Table Elevation (1965) - A map of water table elevation for 1965 is given in the report of Duke and Longenbaugh. For each grid an average figure was determined to the nearest foot from this map. Assuming the map to be accurate, the figures obtained should be correct to \pm 1 foot. These figures were not read into the computer but were used for comparison with the predicted result.

Initial Water Table Elevation (1962) - Using data from well hydrographs, a contour map was constructed showing the change in water table 
elevation from 1962-65. The data were obtained from Bjorklund and Brown, Duke and Longenbaugh, Code and the files of Colorado State University. An average figure of change in elevation, to the nearest $1 / 2$ foot, was read from this map for each grid. This figure was subtracted from the 1965 figure for the grid to obtain the 1962 water table elevation. Errors could occur in this figure due mainly to the sparcity of well hydrographs. However, the areas having few records were those having very small changes in water table elevation.

The 1962 elevation figures were read into the computer and formed the initial, known water table elevation.

Bedrock Elevations - Bedrock elevation figures for each grid were taken from a bedrock map given in Duke and Longenbaugh. These figures were obtained from the map in the same way as the water table elevation figures for 1965 . They were probably more inaccurate since the bedrock contours tended to be more closely spaced than the water table contours. Determination of an average figure for each grid was therefore more difficult. However, the water table elevation figures had a more or less direct effect on the solution, since it was found that an error in the initial figure would be of about the same order of magnitude in the result. The bedrock data, on the other hand, affected results more indirectly, since errors in bedrock elevation caused errors in saturated thickness and thus errors in inflow and outflow to the grid. Since the error was in both inflow and outflow then it tended to be compensatory, and a given error in bedrock data should cause an error of much lower magnitude in the final result.

The bedrock elevation data were read into the computer initially and were held constant for all time steps. 
Permeability - The only figures on permeability in the area are given by Bjorklund and Brown. They suggest $1040 \mathrm{gpd} / \mathrm{ft}^{2}$ for the Bijou basin and $2000 \mathrm{gpd} / \mathrm{ft}^{2}$ for the Kiowa. The Bijou basin is considered to have a lower permeability because of the presence of clay lenses in the aquifer. No data from field tests are given to support these figures and none could be found in the literature. Such average figures are obviously subject to considerable error when used in a study of this type where an average permeability has to be defined for each grid. An attempt was made to approximate variations in the aquifer. The ratios of sand and gravel to silt and clay were calculated using data from well logs. These showed an increase down the valley indicating the presence of proportionally larger amounts of sand and gravel in that direction. As a consequence, the permeability figures were chosen to increase down the valley. Their actual magnitude was determined by trial and error. A number of computer runs were made with different values. Those giving the best correlation between the decline in water table elevation predicted by the model and the actual decline were finally used.

It was found that changes in permeability of a given magnitude did not cause changes of the same magnitude in the predicted results. This conclusion was also reached by Bittinger (1967) who, in addition, showed that the error tends to become smaller if the study period is of several years duration. Thus, although the permeability data carried a high degree of error it did not introduce an error of equal magnitude into the final result. Also, it was likely that, even with permeability data from field tests available, the error would have been considerable due to the highly variable and unpredictable occurrence and extent of clay 
lenses in the aquifer.

The permeability figure finally used for each grid was held constant throughout the period of study.

Specific Yield - Duke and Longenbaugh used a figure of 0.20 for the specific yield for the entire Kiowa-Bijou basin. This figure was to some extent substantiated by a USGS aquifer test, in the lower part of the basin, which gave a figure of 0.17 . The latter was the only field data of specific yield for the basin. Trial computer runs were made with figures for specific yield showing, like the permeability, an increase down the valley. However, they did not give better results than a constant figure of 0.20 , and so this latter figure was used in this study. It was considered to be a good average figure for a predominantly sand-gravel aquifer such as the Kiowa-Bijou, but quite obviously local areas of the basin may vary from this figure. The specific yield was read into the computer initially and held constant throughout the study period.

Precipitation - Precipitation data were available from four stations in and around the study area. Most precipitation over the area was in the form of snow in winter and isolated, intense thunderstorms in summer. Due to the nature of the latter, the precipitation map for each time unit (30 days) of the study period may be inaccurate since distance between stations was sufficient for thunderstorms to miss them entirely. Average annual precipitation and its average monthly distribution were therefore used. Any error between the average figure and the actual figure over the period of study was minimized since only the fraction of precipitation reaching ground water influences this study. Thus, the average annual precipitation was 13.0 inches over the entire area and of this five per 
cent was considered to infiltrate and reach ground water. This amounted to 0.27 feet of saturated thickness when the specific yield was 0.20 . Therefore, if the average precipitation figures were in error by 100 per cent, the saturated thickness would only be incorrect by about three inches.

The five per cent infiltration figure, given by Duke and Longenbaugh, was considered a good average figure, keeping in mind the effects of climate, vegetation, topography and soils of the area.

Modifications to the coefficient of precipitation were made along the creeks and where sand dune deposits occured within the aquifer. For the sand dunes, the figure was increased to 15 per cent and along the creeks of the Bijou valley the figure was changed so that an extra 500 acre-feet per year per six mile stretch of creek reached ground water. This latter figure is given by Duke and Longenbaugh. It was applicable to only the Bijou Creek since floods in this creek flow along its entire length whereas in the Kiowa, flood waters have invariably infiltrated before reaching the study area. The 500 acre-feet were distributed between the grids through which the creek passed in proportion to the length of channel in the grid. Annual precipitation, its monthly distribution and the coefficients of precipitation were read into the computer initially and held constant throughout the study period.

Pumping - Volumes of groundwater pumped were inferred from the amount of electricity used by each well. The assumptions and calculations that are necessary to convert electricity used into volume of water pumped are described by Duke and Longenbaugh. Annual pumped volumes for each well were obtained from unpublished results of Duke and Longenbaugh. These were adapted to annual volumes pumped from each grid. The average 
monthly distribution of pumping figures were used to estimate the volume pumped in each time unit (30 days). It was thought that the pumping data so obtained were of a fairly high order of accuracy, since the electricity data used in the computation were accurate and because errors in pumping volumes of individual wells would be minimized when the volumes were summed for each grid.

The coefficient of pumping, which, for this model, was defined as the fraction of pumped water not returning to ground water, when applied during irrigation, was set at 70 per cent. No information exists in this basin to justify this figure, but, in view of the predominantly sandy nature of the soil and the practice of ditch irrigation, it was considered to be a reasonable average figure. Where sand dunes occurred in the aquifer the coefficient was changed to 60 per cent.

Average monthly distribution of pumping figures and coefficients of pumping were read into the computer initially and held constant for the entire study period. Annual pumping volumes for each grid were read in initially and after every 12 time increments (360 days).

Phreatophytes - Estimates of annual consumptive use by phreatophytes were taken from Bittinger and Stringham's 1963 study of the lower Arkansas River Valley in Colorado. For 100 per cent cover, they estimate that Cottonwoods use 5.5 acre-feet of ground water per acre per year. This rate of loss was used in this study and the cover density was assumed to be 75 per cent. The area covered by phreatophytes in each grid was calculated by planimeter from $7 \frac{1}{2}$ minute topographic maps. Thus, with both the rate of loss per acre and the phreatophyte acreage known for each grid, the annual loss could be calculated. This figure was read into the computer in acre-feet/day and was assumed constant throughout 
the study period.

Discussion of Results

The results of this study were obtained by giving physical interpretation to the discrepancies between the predicted water table elevation and the actual elevation of 1965. Table 1 compares the actual change in water table elevation for 1962-65 with the computed change. Only discrepancies greater than two feet in magnitude and occurring in several adjoining grids were considered. A discrepancy of less than two feet might possibly have been the result of errors in the data used, and a discrepancy in an isolated grid was not considered to be sufficient evidence that some physical influence was affecting the grid.

If the predicted water table elevation was higher than the actual elevation, then the discrepancy was termed positive. Conversely, the discrepancy was negative. Assuming that the data used were accurate, a positive discrepancy meant that some factor which caused water to be lost from the aquifer had not been taken into account in the model. Since it had not been taken into account, there was more water left in storage in the model's aquifer than there ought to be and hence there was a positive discrepancy. A negative discrepancy indicated that a factor which caused water to be gained by the aquifer had been neglected in the model. The following areas had discrepancies:

Area (1) - In the Kiowa Basin directly above the subcrop of the Fox Hills Sandstone, there was a marked negative discrepancy (see figure 11). This was explained by postulating an inflow of water from the Fox Hills Sandstone to the alluvium. Since such an inflow was not taken into account in the model, then the volume of water corresponding to this 
TABLE 1. Actual and Computed Changes in Water Table Elevation in Feet (1962-65).

\begin{tabular}{|c|c|c|c|c|c|c|c|c|c|c|c|c|c|}
\hline & & & & & & Row N & umber & & & & & & \\
\hline & 2 & 3 & 4 & 5 & 6 & 7 & 8 & 9 & 10 & 11 & 12 & 13 & 14 \\
\hline 17 & & & & 0.25 & $\begin{array}{c}.5 \\
1.75\end{array}$ & 1. & $\begin{array}{l}2 . \\
3.5\end{array}$ & $\begin{array}{l}2 . \\
3 .\end{array}$ & $\begin{array}{l}3 . \\
3.5\end{array}$ & $\begin{array}{l}\text { 3. } \\
\text { 2. } 25\end{array}$ & $\begin{array}{l}3 . \\
2.25\end{array}$ & $\begin{array}{l}\text { 2. } \\
1.25\end{array}$ & \\
\hline 16 & & & & $\begin{array}{c}.5 \\
11.25\end{array}$ & $\begin{array}{l}1 . \\
9 .\end{array}$ & $\begin{array}{c}2 . \\
26.5\end{array}$ & $\begin{array}{r}2 . \\
22 \text {. }\end{array}$ & $\begin{array}{l}2.5 \\
5.25\end{array}$ & $\begin{array}{l}4 . \\
3.25\end{array}$ & $\begin{array}{l}4 . \\
2 .\end{array}$ & $\begin{array}{l}4 . \\
4 .\end{array}$ & $\begin{array}{l}3.5 \\
6.75\end{array}$ & $\begin{array}{l}2.5 \\
3.75\end{array}$ \\
\hline & & 0. & .5 & 2. & 2. & 1. & & & 5.5 & 6.5 & 8. & 6. & 4.5 \\
\hline 15 & & 1. & 5. & 19.25 & 13.75 & 4.25 & & & 6.75 & 5.25 & 7.5 & 8.25 & 5.5 \\
\hline 14 & & $\begin{array}{l}1 . \\
2 .\end{array}$ & $\begin{array}{l}2 . \\
+1.75\end{array}$ & & & & & & & $\begin{array}{l}6.5 \\
6.25\end{array}$ & $\begin{array}{l}8 . \\
5 .\end{array}$ & $\begin{array}{r}9 . \\
10 .\end{array}$ & $\begin{array}{r}7.5 \\
11 .\end{array}$ \\
\hline 13 & $\begin{array}{r}2 . \\
10 .\end{array}$ & $\begin{array}{l}2 . \\
5 .\end{array}$ & $\begin{array}{r}1 . \\
+1.5\end{array}$ & & & & & & & $\begin{array}{l}\text { 5. } \\
5.5\end{array}$ & $\begin{array}{l}7.5 \\
7 .\end{array}$ & $\begin{array}{l}8 . \\
9.25\end{array}$ & $\begin{array}{l}6.5 \\
7.5\end{array}$ \\
\hline 12 & $\begin{array}{l}1 . \\
5.75\end{array}$ & & & & & & & & & $\begin{array}{l}\text { 3. } \\
\text { 3. } 75\end{array}$ & $\begin{array}{l}6 \\
8.75\end{array}$ & $\begin{array}{r}9 . \\
17 .\end{array}$ & $\begin{array}{l}8 . \\
8.75\end{array}$ \\
\hline 11 & & & & & & & & & $\begin{array}{l}4 . \\
6.75\end{array}$ & $\begin{array}{l}5 . \\
13.25\end{array}$ & 70. 75 & $\begin{array}{l}7.5 \\
9.0\end{array}$ & $\begin{array}{l}6.5 \\
6 .\end{array}$ \\
\hline 10 & & & & & & & $\begin{array}{l}5 . \\
7.5\end{array}$ & $\begin{array}{l}5.5 \\
4.75\end{array}$ & $\begin{array}{l}6 . \\
17.25\end{array}$ & $\begin{array}{c}6.5 \\
23.25\end{array}$ & $\begin{array}{l}6 . \\
15.75\end{array}$ & $\begin{array}{l}5 . \\
6.25\end{array}$ & $\begin{array}{l}4 . \\
+9.25\end{array}$ \\
\hline 9 & & & & & & & $\begin{array}{l}2.5 \\
7.25\end{array}$ & $\begin{array}{l}\text { 4. } \\
4.25\end{array}$ & $\begin{array}{l}5 . \\
14.75\end{array}$ & $\begin{array}{l}4 . \\
14.25\end{array}$ & $\begin{array}{r}3 . \\
11 .\end{array}$ & $\begin{array}{l}2.5 \\
8.75\end{array}$ & $\begin{array}{l}2 . \\
+.25\end{array}$ \\
\hline 8 & & & & & & +1.5 & $\begin{array}{l}\text { 2. } \\
2.25\end{array}$ & $\begin{array}{l}\text { 3. } \\
4.75\end{array}$ & $\begin{array}{l}\text { 2. } \\
6.75\end{array}$ & $\begin{array}{l}1 . \\
5.25\end{array}$ & 2.5 & $\begin{array}{l}0 . \\
0 .\end{array}$ & $\begin{array}{l}0 . \\
+.75\end{array}$ \\
\hline 7 & & & & & $\begin{array}{l}0 . \\
1 .\end{array}$ & 1. 5 & ${ }^{2 .} .25$ & $\begin{array}{l}1 . \\
3.25\end{array}$ & $\begin{array}{l}0 . \\
1 .\end{array}$ & $\begin{array}{r}0 . \\
+2 .\end{array}$ & $\begin{array}{r}0 . \\
+3 .\end{array}$ & $\begin{array}{l}0 . \\
+3.25\end{array}$ & $\begin{array}{r}0 . \\
+2 .\end{array}$ \\
\hline 6 & & & & 0.5 & $\begin{array}{r}.5 \\
3.5\end{array}$ & $\begin{array}{l}1.5 \\
8 .\end{array}$ & $\begin{array}{l}1.5 \\
9.5\end{array}$ & $\begin{array}{l}0 . \\
1 .\end{array}$ & $\begin{array}{l}0 . \\
0 .\end{array}$ & $\begin{array}{l}0 . \\
+9.25\end{array}$ & $\begin{array}{r}0 . \\
+9\end{array}$ & $\begin{array}{l}0 . \\
+8.5\end{array}$ & \\
\hline 5 & & & $\begin{array}{l}0 . \\
1 .\end{array}$ & $\begin{array}{l}.5 \\
.75\end{array}$ & $\begin{array}{r}1.5 \\
.5\end{array}$ & $\begin{array}{l}2 . \\
3.25\end{array}$ & $\begin{array}{l}\text { 1. } \\
4.75\end{array}$ & $\begin{array}{l}0 . \\
4.25\end{array}$ & $\begin{array}{l}0 . \\
4 .\end{array}$ & $\begin{array}{l}0 . \\
2.75\end{array}$ & $\begin{array}{l}0 . \\
4 .\end{array}$ & $\begin{array}{r}0 . \\
+11.25\end{array}$ & \\
\hline 4 & & $\begin{array}{l}0 . \\
.25\end{array}$ & $\begin{array}{l}.5 \\
1.75\end{array}$ & $\begin{array}{l}1 . \\
2.5\end{array}$ & $\begin{array}{l}2.5 \\
2.25\end{array}$ & $\begin{array}{l}1.5 \\
2.0\end{array}$ & $\begin{array}{c}.5 \\
1.75\end{array}$ & 0.75 & $\begin{array}{l}0 . \\
2.25\end{array}$ & $\begin{array}{l}0 . \\
4.75\end{array}$ & $\begin{array}{l}0 . \\
3.75\end{array}$ & $\begin{array}{c}0 . \\
+2.5\end{array}$ & \\
\hline 3 & & $\begin{array}{l}0 . \\
1 .\end{array}$ & $\begin{array}{l}.5 \\
.5\end{array}$ & $\begin{array}{l}1.5 \\
2.75\end{array}$ & $\begin{array}{l}2 . \\
4 .\end{array}$ & $\begin{array}{l}.5 \\
1.25\end{array}$ & $\begin{array}{l}0 . \\
+.5\end{array}$ & & & & 0.25 & 0.5 & \\
\hline 2 & & $\begin{array}{c}0 . \\
+1.2\end{array}$ & 0.5 & 2. 5 & $\begin{array}{l}1.5 \\
1.5\end{array}$ & $\begin{array}{l}.5 \\
2.25\end{array}$ & $\begin{array}{l}0 . \\
2 .\end{array}$ & & & & $\begin{array}{l}0 . \\
2 .\end{array}$ & $\begin{array}{l}0 . \\
2.5\end{array}$ & $\begin{array}{l}0 . \\
+2.25\end{array}$ \\
\hline
\end{tabular}

(a) Figures for computed change take into account all inflow and outflow factors except evapotranspiration along Muddy Creek and inflow from the Fox Hills Sandstone.

(b) For each grid computed change is written beneath actual change.

(c) Values of dune inflow and loss to phreatophytes are given in the Appendix. 


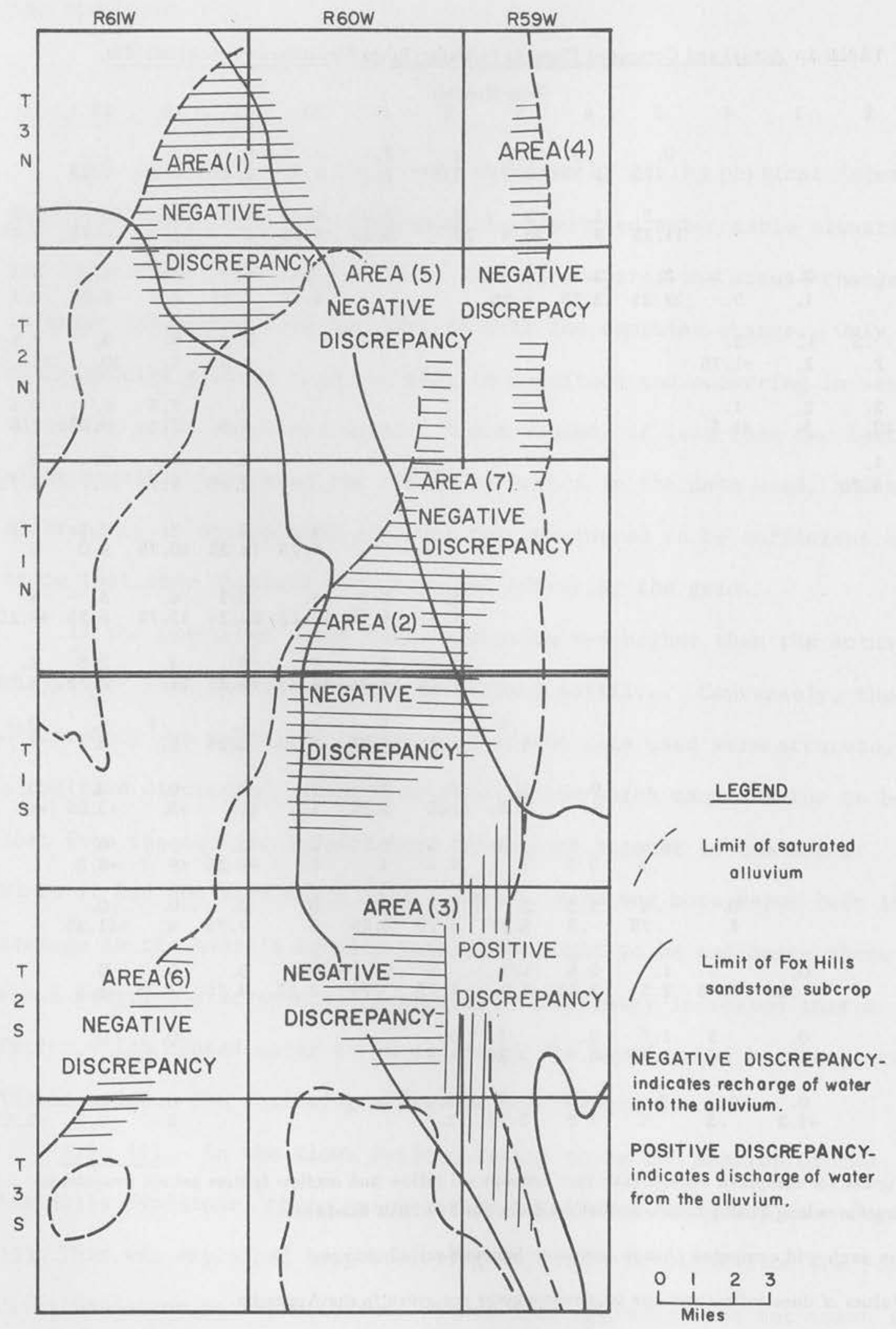

Figure 11. Areas showing discrepancies between computed and actual drawdown. 
inflow was lacking and so showed up as a negative discrepancy. This supposition was supported by the fact that the area was one of the most heavily pumped in the basin but did not have a compatible decline of water table elevation. It will be appreciated that, if water was entering the alluvium from the Fox Hills Sandstone, the piezometric level of the Fox Hills aquifer had to be higher than the water table in the alluvium.

Area (2) - In the Bijou basin a similar area of negative descrepancy occurred in T1S, R60W where the alluvium overlies the Fox Hills Sandstone. This was again interpreted as an area in which water was entering the alluvium from the Fox Hills Sandstone. It also had heavy pumping and it would be expected that the piezometric surface of the Fox Hills Sandstone was higher than the alluvial water table.

Area (3) - In T2S, R60W where the alluvium overlies the Fox Hills Sandstone, there was a marked positive discrepancy in the eastern part of the area and a less marked negative discrepancy in the western part. Muddy Creek flows northwards through the eastern part of the area. A comparison of water table contours and land surface contours showed that along a narrow zone adjacent to the creek the ground water was at the surface. A field excursion verified this and found water at several points along the creek. The water was up to six feet deep in places and generally occurred in more or less isolated ponds, there being little flow. Luxuriant plant growth paralleled much of the creek. There were fish in the water and an abundance of insect life. All of these testified to the permanence of the water and indicated that there must be evapotranspiration losses of ground water along Muddy Creek. These would account for at least part of the positive discrepancy. 
A positive discrepancy could also be explained by postulating a loss of water from the alluvium to the Fox Hills Sandstone. However, the presence of a negative discrepancy in the western part of area (3) indicated that flow was from the Fox Hills Sandstone to the alluvium, and that the piezometric surface must therefore have been higher than the water table. Since, in the eastern part, the water table was unusually low, due to the evapotranspiration losses along Muddy Creek, it seemed reasonable to deduce that here also the piezometric surface was above the water table. This would indicate that the positive discrepancy was due entirely to the evapotranspiration 1oss, and further that the rate of this loss was greater than the rate of inflow from the Fox Hills Sandstone. To try to demonstrate this, estimates were made of evapotranspiration losses along Muddy Creek and incorporated into the model. They resulted in most of the positive discrepancies being reversed to negative ones. This suggested that if there were no evapotranspiration losses, the entire area would have showed a negative discrepancy indicating flow from the Fox Hills Sandstone to the alluvium.

Areas (4), (5), (6) - Each of these three areas showed a negative discrepancy, and a study of their surface geology revealed that areas (4) and (5) were adjacent to areas of stabilized dune sand and area (6) was adjacent to an area having predominantly sandy soils. It would seem possible that these sand areas are zones of especially high infiltration of precipitation and that this infiltrated water was draining laterally into the aquifer. This hypothesis was based on reasonably firm foundations. Reddell (14), in a study of the High Plains of Colorado, found that locally sand dune areas were contributing six out of 18 inches of precipitation of groundwater. Also, a field study showed that areas (4) and (5) 
consisted of closed, shallow depressions separated by divides of approxinately equal elevation. The drainage was internal, each depression acting as an isolated drainage basin. The dunes were stabilized and covered with sparse vegetation. Thus, the naturally high infiltration rate of sand dunes is enhanced by the surface topography. Area (6) had sandy soils but did not have an internal drainage system. Several small creeks drained toward the West Bijou Creek. These creeks were short in length and very poorly developed, so that it was thought that the volume of water carried by the creeks would be small and that most of this water would infiltrate before reaching West Bijou Creek. Thus, even though the area did not have internal drainage the proportion of precipitation reaching the aquifer should be about the same as in areas (4) and (5). The water table contours showed a downstream inflection in these areas which indicated a flow of groundwater from the neighboring sand dunes. An analysis was made to determine the size of the dune area which contributed water to the aquifer. This area was defined by a study of bedrock contours. If the latter indicated that the drainage of an area was towards the study area, then it was assumed that precipitation, infiltrating into the sand dunes above such an area, would also drain to the aquifer. Various coefficients were tried in the model to estimate the fraction of precipitation that was infiltrating into the sand dunes. It was found that a figure of 30 per cent eliminated the negative discrepancy and since this is a reasonable figure for dune infiltration, it was used in the model. The water infiltrating into the dunes was considered to reach the saturated part of the aquifer in the grid immediately adjacent to the point at which it infiltrated. 
Area (7) - In an area of T1N, R60W, to the North-East of the Fox Hills Sandstone subcrop, there were negative discrepancies. This area lies along the path of the deepest part of the buried channel of Bijou Creek. Well logs indicated that the alluvium directly above the bedrock was almost entirely gravel. It would seem possible that water was passing through this gravel from the alluvium overlying the Fox Hills Sandstone to account for this area of negative discrepancy.

Volume of Flow between Fox Hills Sandstone and Alluvium - Calculations were made to estimate the net amount of flow between the Fox Hills Sandstone and the alluvium. The actual loss in storage from the alluvium over the study period was calculated in the following way:

$$
\begin{aligned}
\text { Loss }=\text { D.Sy.A } & =(334.5)(0.20)(2)(640) \\
& =85,640 \text { acre-feet }
\end{aligned}
$$

Where, $\mathrm{D}=$ sum of actual drawdowns in each grid for $1962-65$. Sy = specific yield. $A=$ Area of a grid.

The loss of storage over the three years, in the model, was 130,000 acre-feet. This took into account all inflow and outflow factors except the gain of water from the Fox Hills and the loss to evapotranspiration along Muddy Creek. It was concluded that the difference between this computed loss of storage and the actual loss was due to these two factors. If the evapotranspiration loss was estimated to be 4,500 acre-feet for three years, then the contribution from the Fox Hills Sandstone to the alluvium was 19,000 acre-feet per year.

The accuracy of this 19,000 acre-feet net inflow is difficult to determine without detailed error analysis. However, computer runs were 
made using data which would give the greatest and the least loss of water from storage in the alluvium. For the greatest loss from storage, the permeability was decreased at the southern end of the basin, where subsurface inflow occurs, and increased at the northern end, where there is subsurface outflow, so that the coefficient of permeability ranged from 70 to 330 feet per day. The coefficient of pumping was increased to 80 per cent and the coefficient of precipitation reduced to 3 per cent. It was found that the contribution from the Fox Hills Sandstone to the alluvium would have to be 34,000 acre-feet per year in order that the actual and predicted changes in storage over the study period would be equal. To get the least loss from storage, permeability was increased at the southern end of the basin and decreased at the northern giving a range from 100 to 300 acre-feet per day. The coefficient of pumping was reduced to 60 per cent and the coefficient of precipitation increased to 10 per cent. With these figures, there would have to be a loss of 4500 acre-feet per year from the Fox Hills Sandstone to the alluvium. Since the data used in these runs were the maximum and minimum acceptable values respectively, the inflow figures obtained may be taken as the 1 imits of the range of possible inflow figures, with 19,000 acre-feet per year the average and most probable figure.

Conclusions for the Kiowa-Bijou Basin

1. Along the entire subcrop of the Fox Hills Sandstone, in the Kiowa-Bijou basin, groundwater is flowing from the Fox Hills Sandstone into the alluvium. The magnitude of the flow was found to be approximately 19,000 acre-feet per year during the period 1962-65. This figure is thought to have an accuracy of $\pm 15,000$ acre-feet. 
2. The groundwater of the alluvium is supplemented by flow from adjacent sand dune areas along both sides of the northern part of the Bijou basin and along the western side of the southern part of the basin. The volume of the inflow during the study period was approximately 6000 acre-feet per year.

3. Loss of groundwater through evapotranspiration is occurring along Muddy Creek. This loss is greater than the inflow of water from the Fox llills Sandstone in this area. An approximate figure for the loss is 4500 acre-feet per year during 1962-65.

4. Phreatophytes along parts of Bijou Creek are responsible for a minor loss of groundwater from the alluvium. This amounted to approximately 3000 acre-feet per year during 1962-65. 


\section{APPLICATION OF NUMERICAL MODEL-BLACK}

SQUIRREL BASIN

Location of the Black Squirrel Basin

The area studied is the Upper Black Squirrel Creek Basin, E1 Paso County, Colorado. The basin includes all the area north of latitude $38^{\circ} 40^{\prime}$ drained by Black Squirrel Creek and its tributaries; West Fort of Black Squirrel Creek, Brackett, and Big Spring Creek. Within the 350 square miles of the basin, the relief is 2100 feet, ranging from 7700 feet in the north to 5500 feet in the south. Figure 12 shows the location of the basin, the area covered by mathematical model, and pertinent cultural features.

This portion of the study deals with the hydrogeology of the Black Squirrel Creek Basin. The purpose of the study was to evaluate ground water movement in the basin by using a mathematical model. Previous investigation (Kuhn, 1968; Bibby, 1969, Bibby and Sunada, 1971) indicated a possibility that the bedrock underlying the saturated alluvium in the Black Squirrel Creek Basin might be a recharge source for the same bedrock formations outcropping 110 miles to the north in the Kiowa-Bijou District. The mathematical model described in Section II was used to determine if water is being transferred into or out of the bedrock underlying the alluvial aquifer and to give a quantitative figure for grains or losses.

Previous Investigations

The first geologic mapping of the study area was done for the United States Geological Survey (by Finlay) in 1916. In 1936 Dane and 


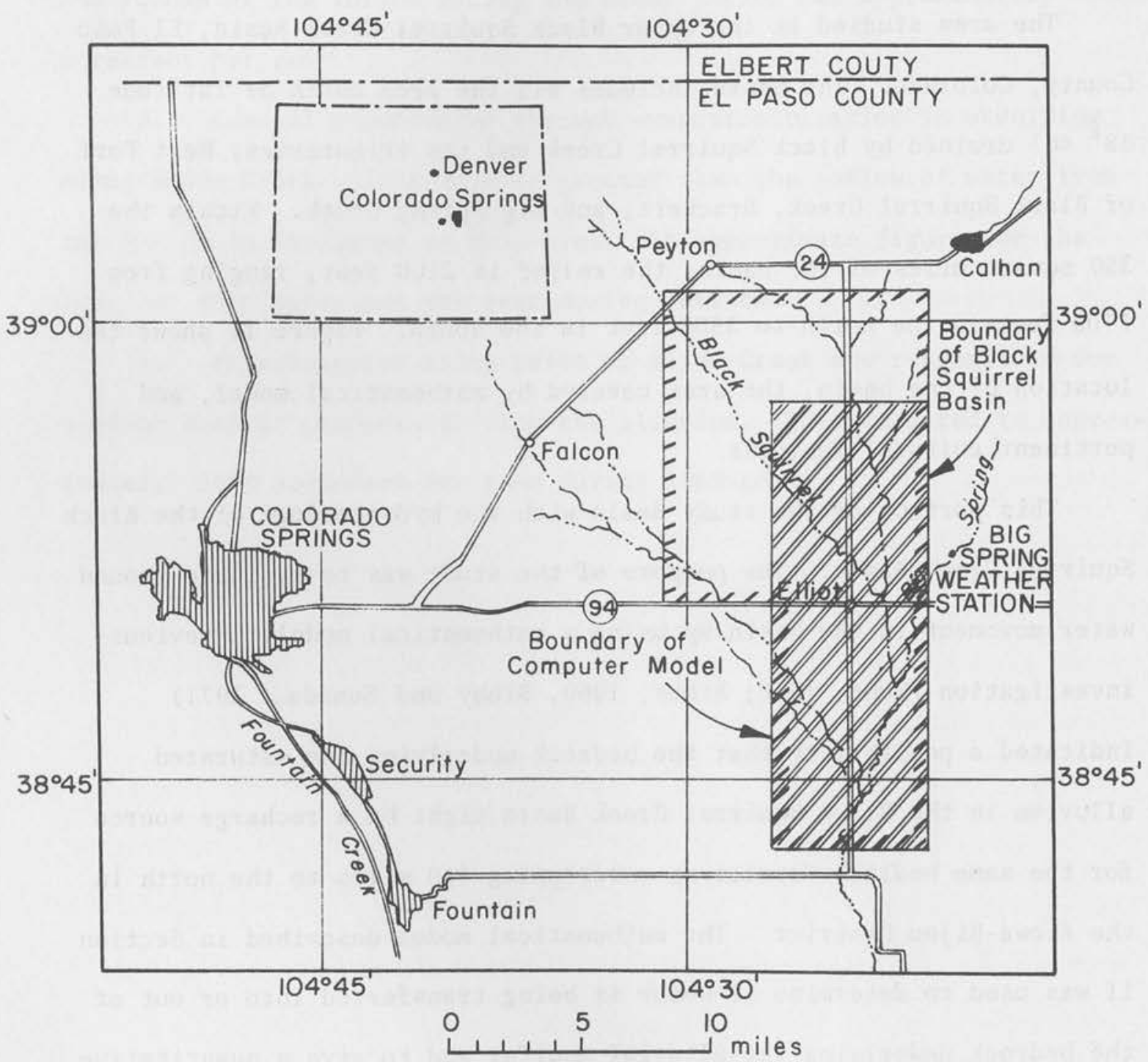

Figure 12. Location of Black Squirrel Basin. 
Pierce published a report on the Dawson and Laramie Formations in the southeastern part of the Denver Basin, including a geologic map of the Black Squirrel Basin. More recently, the northeastern part of the study area has been described by McLaughlin (1946) and the extreme southern portion has been mapped and described by Soister (1968). In 1966 McGovern and Jenkins prepared a brief hydrologic atlas covering the entire basin. Erker and Romero (1967) prepared a report concerning the ground water resources of the area for the Colorado Ground Water Commission. Largely on the basis of the Erker and Romero report, the Black Squirrel Creek drainage became a Designated Ground Water Basin under Colorado law in 1967. Since 1964 Woodward, Clyde, and Associates, on behalf of the Cherokee Water District, have made yearly reports on ground water conditions in the basin. In 1965, Charles Fisk, a consulting engineer, prepared a Status Report on Ground Water Investigations in the Black Squirrel Creek valley. Geoke (1970) presents a complete report on the hydrology of the Black Squirrel Basin.

\section{Geology}

Stratigraphy - The Black Squirrel Creek Basin is located on the southern rim of the Denver Basin with the surface topography sloping south to the Arkansas River and underlying strata dipping gently northward into the Denver Basin.

The rocks that crop out in the Black Squirrel Creek Basin are sedimentary and range in age from Upper Cretaceous to Early Tertiary. Bedrock formations from oldest to youngest are: Pierre, Fox Hills, Laramie, and Dawson Formations. Younger (Pleistocene and Recent) units 
in the area are dune sands, colluvium, and alluvium underlying present drainage channels. Figure 13 shows the geology of the study area (after Erker and Romero, 1967, and Soister, 1968). Figure 14 shows a north-south geologic cross section through the basin.

The following stratigraphic description will be hydrogeologic in nature to indicate the potential effect of the bedrock underlying the Black Squirrel Creek Basin on local ground water resources. Figure 15 is a generalized stratigraphic column of the strata in the Black Squirrel Creek Basin.

Pierre Formation (Upper Cretaceous) - The Pierre Formation in the Denver Basin varies from 0-8000 feet in thickness, and only the upper 800 feet outcrops at the very southern end of the Black Squirre1 Creek Basin (Fogarty, 1952, p. 81). This upper portion is called the transition zone and includes the 800 feet of beds lying below the mappable sandstone beds of the Fox Hills Formation. It is composed of gray, blue, and buff shales, siltstone and sandy shale, scattered buff calcareous concretions, sandstones, and several thin gray-to-buff concretionary beds. A small quantity of water may be lost to the transition zone, but it would nevertheless be classed as an aquiclude. Fox Hills Formation (Upper Cretaceous) - The Fox Hills grades downward into the Pierre and upward into the Laramie, contacts being conformable and gradational, so exact placement of boundaries for the formation has been difficult.

In the Denver Basin the Fox Hills varies in thickness from 0-700 feet. In northeastern Colorado, Mather et al. (1928) placed the upper boundary of the Fox Hills at the top of the Milliken sandstone member which Henderson (1920, p. 22) named and described as follows: 


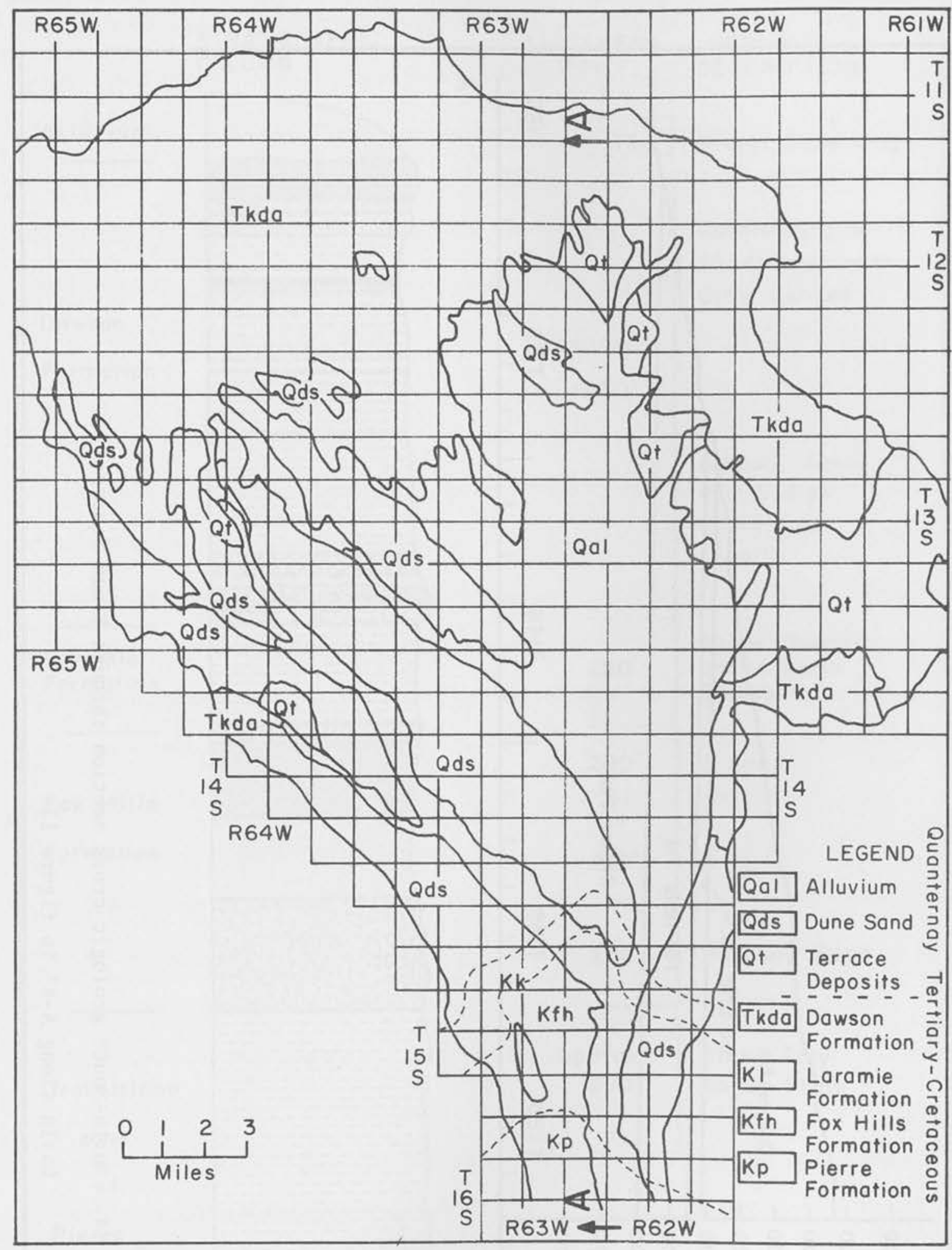

Figure 13. Geology of Black Squirrel Basin. 


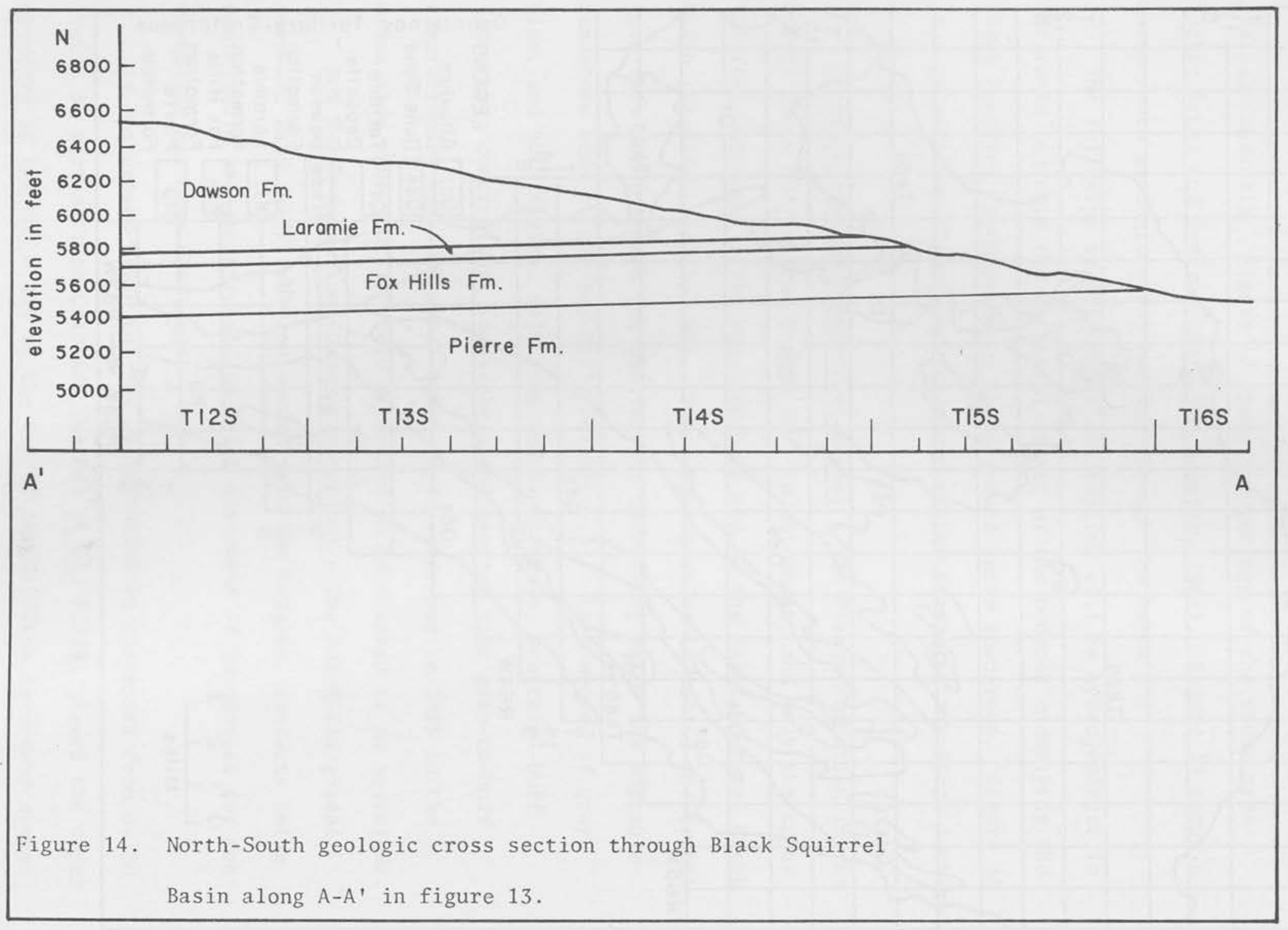




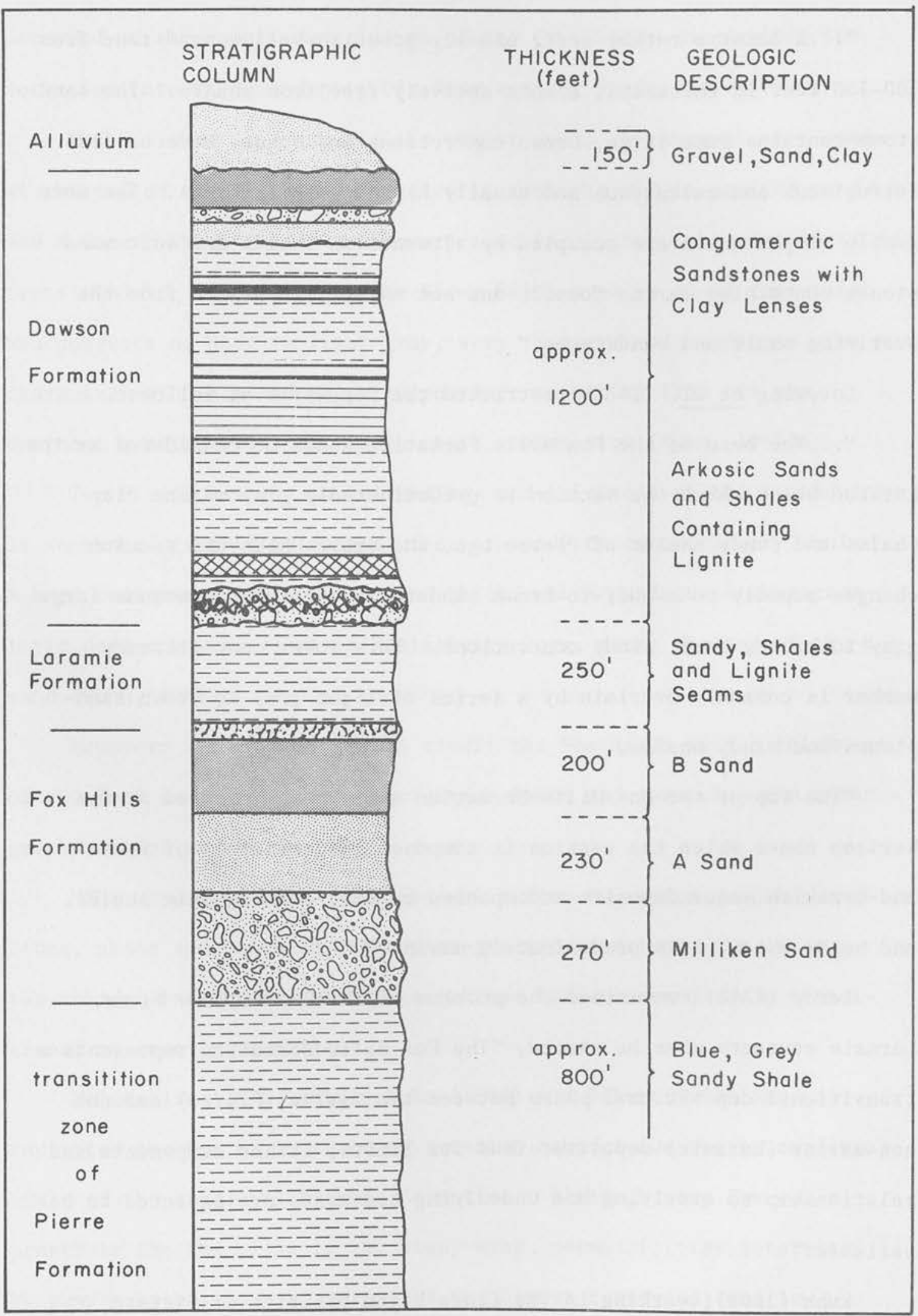

Figure 15. Generalized Stratigraphic Column of Strata in Black Squirrel Creek Basin. After Kuhn, 1968, and Reichert, 1956. 
"...a massive rather soft, usually greenish-yellow sandstone from 100-150 feet in thickness, almost entirely free from shales. The sandstone contains some large, brown concretions and bands, more or less ferruginous and calcareous and usually highly fossiliferous. The more gentle slopes above are occupied by alternating shales and soft sandstones containing marine fossils and not sharply separated from the overlying shale and sandstones."

Lovering et al. (1932) restricted the Fox Hills as follows:

"...The base of the Fox Hills Formation shall be considered as the horizon below which the section is predominatedly gray marine clay shales and sandy shales of Pierre age, and above which the section changes rapidly to a buff-to-brown sandstone containing numerous large gray to brown, hard, sandy concretions. This lower concretionary member is commonly overlain by a series of light gray to brown sandstones and sandy shales.

"The top of the Fox Hills Formation shall be considered as the horizon above which the section is composed predominately of freshand-brackish water deposits accompanied by coal and lignitic shales, and below which it is predominately marine."

Leroy (1944) summarized the problem of the Fox Hills - PierreLaramie contacts when he stated, "The Fox Hills formation represents a transitional depositional phase between the marine (Pierre) and the non-marine (Laramie) deposits; thus its limits, lithic components and relationship to overlying and underlying sediments are expected to be variable."

Kuhn (1968), working in the Kiowa-Bijou District of eastern Colorado (110 miles NNE of the Black Squirrel Creek Basin) provides a 
detailed stratigraphic description of the Fox Hills. He divides the formation into three and possibly four aquifer sands.

The Milliken sandstone is the lowest sand. A concretionary zone at the top of the Milliken separates it from the middle aquifer sand, and $\mathrm{A}$ sand. Where the concretionary zone is missing, the contact is transitional. The A sand in the Kiowa-Bijou area is 40-60 feet thick and consists of buff to light gray, very fine grained sandstone with a characteristic salt and pepper appearance resulting from its predominant quartz, feldspar, and biotite composition (Kuhn, 1968).

The B sand has the same lithology and thickness as the A sand and is separated from it by several feet of sandy to concretionary shale. A hard calcareous cap up to 6 feet thick, which produces a characteristic deflection on electric resistivity logs, marks the top of the B sand (Kuhn, 1968).

McGovern and Jenkins (1966) credit the Fox Hills with a thickness of 700 feet in the Black Squirrel Creek Basin and summarize the stratigraphy as follows:

"The upper one third, massive white fine-to-medium-grained sandstone, shale and greenish brown fine-grained sandstone; the lower two-thirds, interbedded very fine-grained sandstone and shale transitional to underlying shale."

McLaughlin (1946, 1955), Kuhn (1968) and Bibby (1969) have all indicated the Fox Hills to be an artesian aquifer due to the confining shale of the overlying Laramie Formation. Although very few wells penetrate the Fox Hills in the study area, permeabilities determined by pumping tests in other areas of the Denver Basin indicate low permeabilities of 2 and $6 \mathrm{gpd} / \mathrm{ft}^{2}$ for the Fox Hills (McLaughlin, 1955). 
Erker and Romero (1967) report yields from the Fox Hills at 70-80 gallons per minute with large drawdowns further indicating a low permeability for the formation.

$$
\text { Laramie Formation (Upper Cretaceous) - Horner (1954) gives a }
$$

succinct history of the Laramie Formation. The Laramie, if including the $A$ and $B$ sands earlier attributed to the Fox Hills, is divisible into two parts, a lower of sandstones and an upper composed mostly of siltstone, shale, clay and coal. Because the Milliken, A and B sands are primary aquifer sands, they will be included in this paper as one unit, the Fox Hills.

Soister (1968) acknowledges the upper and lower members of the Laramie as mappable units in the Black Squirrel Creek Basin. He describes the upper member as consisting of shale, sandstone, and coal beds. The shale is yellowish gray to olive gray or grayish brown where carbonaceous. The sandstone is mostly in beds $1-10$ feet thick, soft to hard, partly calcareous, light gray to yellowish gray, and fine to medium grained. Some beds have small to large calcareous sand and ironstone concretions. As many as three beds of subbituminous coal ranging in thickness from 1-10 feet are present.

Where the Laramie Formation outcrops in the Black Squirrel Creek Basin, the maximum thickness of the upper Laramie section would be approximately 150 feet. McLaughlin (1946), Erker and Romero (1967) and Soister (1968) disagree over the thickness of the unit. The 150 feet figure is an average of these sources, agreeing partially with the maximum thickness figures given in the U.S.G.S. Hydrologic Atlas by McGovern and Jenkins (1966). 
The Laramie, considered as the coals and shales above the A and B sands assigned to the Fox Hills Formation, would be considered an aquiclude. Water present in the sandstone lenses is not transmitted due to their discontinuous nature and intervening clays and shales. Thus the Laramie aquiclude promotes a potential artesian situation for the Fox Hills Sandstone which it overlies.

Dawson Formation (Cretaceous and Tertiary) - Original reference to the Dawson Formation was made by Richardson in 1915. Later workers in eastern Colorado were Dane and Pierce (1936), Brown (1943), and Reichert (1956). In eastern Colorado the Dawson Formation is 1000-2000 feet thick and consists of arkosic conglomerates and sands. North of the study area the Dawson merges into the Denver and Arapahoe Formation along the foothills of the Front Range.

The upper part of the Dawson is coarsely conglomeratic, but lower parts consist chiefly of arkosic sands, dark shales, and beds of lignite. There is also a prominent conglomerate bed at the base of the formation.

The Dawson underlies most of the study area with the exception of the limited outcrop areas of the Pierre, Fox Hil1s, and Laramie Formations. Due to its thickness and low dip angle, only the lower part of the Dawson underlies the study area. The lower Dawson is made up primarily of clay and shale, with sand, sandstone, and conglomerate being a minor part. To the north of the study area, wells penetrating the sandstones of the lower Dawson encounter water under artesian pressure (McLaughlin, 1946). Although the Dawson Formation is relatively impermeable, the discontinuous or lenticular sandstones within the formation would be considered aquifers where present. 
Valley Fill Alluvium (Pleistocene) - Soister (1968) has dated the valley fill alluvium in the Black Squirrel Creek Basin area as late Pleistocene. The valley fill is mostly gravelly sand and includes some beds of grave1, silt, and clay. Only the upper part is exposed, and this ranges from small pebble gravel to arkosic gravelly sand. It is light-yellowish-gray to grayish-orange and contains mostly granite, quartz, and feldspar pebbles that are angular to subrounded. The alluvium, by texture and composition, indicates derivation from the Dawson Formation or from the same source as the Dawson.

The valley fill alluvium is the principal aquifer in the study area. It varies in thickness from a few feet on the east and west edges of the area to a maximum of 200 feet where it fills channels incised into the bedrock. McGovern and Jenkins (1966) conducted three pumping tests in the main channel alluvium which produced permeabilities ranging from $630-1100 \mathrm{gpd} / \mathrm{ft}^{2}$. Erker and Romero (1967) report that the range of permeabilities may be greater than the pumping tests indicated and suggest higher permeabilities near the southern boundary.

Dune Sands (Recent) - Soister (1968) working in the southern end of the study area divides the Recent deposits into eolian sand, Piney Creek alluvium, colluvium, and Recent alluvium. Approximately $12 \%$ of the study area is mantled by Recent dune sands. The dunes consist of fine to very coarse-grained sand and granules and contain occasional pebbles up to $10 \mathrm{~mm}$. in length (Soister, 1968). The grains are frosted and subrounded to well rounded quartz with lesser amounts of feldspar and granite. The dunes generally form ridges trending southeast. The source material for the dunes is apparently the alluvium to the northwest: These eolian sand dunes range in thickness from 10-40 feet. The 
dunes serve as an excellent catchment area for precipitation, but lying above the water table, yield little or no water to wells.

Piney Creek Alluvium (Recent) - The Piney Creek Alluvium is described by Soister (1968) as alluvial and pond or bog deposits consisting primarily of clayey sandy silt and silty sand. The pond and bog deposits are very clayey, becoming more gravelly along the main streams. This alluvium varies from 5-35 feet in thickness. It yields small quantities of water to domestic and stock wells and locally contains perched water above the general water table.

Colluvium and Alluvium (Recent) - The colluvium is locally derived, primarily from the outcrop of the Fox Hills Sandstone on the south end of the study area called the Crows Roost. It consists of poorly sorted silts and sands that are grayish-yellow to dark-yellowish-orange. Maximum thickness is 10 feet.

The alluvium is composed of sand, gravel, and silt located in present stream channels. Thickness is usually less than 15 feet with the exception of occasional terrace and flood plain deposits. Both colluvium and alluvium are minor sources of water, supporting only occasional domestic or stock wells.

Geologic Maps - Soister has mapped the southern portion of the area on the Geologic Map of the Hanover NW Quadrangle, E1 Paso County, Colorado, 1968. Erker and Romero have mapped the entire Upper Black Squirrel Creek Basin in less detail for the State Engineers Office, 1967. Soister's work is more detailed and has been used as the primary source for description of the Pleistocene and Recent deposits. However, since Soister only covers a small portion of the area, the less detailed 
geologic map of Erker and Romero is the basis of the geologic map presented in figure 13 .

\section{$\underline{\text { Data Used }}$}

Basic Data - The following parameters were defined for each grid. Actual grid values for each parameter are given in the Appendix unless otherwise stated.

(i) Final Water Table Elevation (1970) - Field measurements taken in March, 1970 were used to prepare a water table elevation contour map of the study area. Average water table elevations for each grid were determined from this map and used for comparison with computed water table elevations for 1970 .

$$
\text { (ii) Initial Water Table Elevation (1966) - Water table }
$$

elevations for March, 1966 were available from Erker and Romero (1967). Similar points from the 1970 and 1966 measurements were compared and their differences were plotted and contoured. Water level changes were read from the contoured differences and added to the 1970 water table elevations to give initial water table elevations in each grid for 1966 .

(iii) Bedrock Elevations - Bedrock contour maps were available from Erker and Romero (1967), McGovern and Jenkins (1966), and the consulting firm of Woodward, Clyde, and Associates. An average bedrock elevation for each grid was estimated from each source. The differences between these three values varied from 0-150 feet with an average variation of 40 feet per grid. This wide variation necessitated averaging of the three available figures and using this average as the bedrock elevation in each grid. 
(iv) Permeability - McGovern and Jenkins (1966) present the results of three aquifer tests conducted in the valley alluvium of the study area. The three permeability figures vary from $84 \mathrm{ft} /$ day to $147 \mathrm{ft} /$ day. The lowest figure obtained was at the northern boundary and the remaining two from the middle of the study area. From the hetrogeneous nature of the valley alluvium the permeability figures can be expected to vary widely throughout the area. The general indication is of an increase in permeabilities downstream towards the southern boundary. Accordingly, permeability figures were assigned column by column, increasing by increments of $5 \mathrm{ft} /$ day from an initial figure of $10 \mathrm{ft} /$ day at the north boundary to $105 \mathrm{ft} /$ day at the south boundary. The linearly varying of permeability figures were read into the computer initially and held constant throughout the study period. (v) Specific Yield - Bibby's (1969) work in the Kiowa-Bijou region north of the Black Squirrel Creek area indicated a specific yield of 0.20 to be a satisfactory value for the alluvial aquifer in that area. The nature of the alluvial aquifer in these two areas is similar; therefore an initial specific yield of 0.20 was assigned to al1 saturated grids in the Black Squirrel Creek Basin and held constant throughout the study period.

(vi) Precipitation - Precipitation data were available from two stations, one on each side of the study area; Colorado Springs to the west and Rush to the east. The Big Springs Ranch weather station was situated adjacent to the study area, but lacked sufficient historical record to be used. The Rush and Colorado Springs stations annual averages were only $0.03^{\prime \prime}$ different, so an average of the two was assumed to give a satisfactory representation for rainfall on the 
area between stations. Any error introduced by scattered thundershowers between the measuring stations might introduce short term inaccuracies. Assuming $5 \%$ of rainfall infiltrates the ground water, only $3.3^{\prime \prime}$ of saturated thickness (specific yield $=0.20$ ) per year would result from the annual rainfall of $13.2^{\prime \prime}$. Eighteen inches of rainfall per year would be necessary to raise this figure to 4 " per year. Thus localized thundershowers would have little effect on water levels.

Duke and Longenbaugh (1966) present a $5 \%$ infiltration figure. Using this as an average effective precipitation figure, grid values were adjusted according to the surface deposits mapped by Erker and Romero (1967). Values ranged from $5 \%$ for alluvium to $15 \%$ for dune sand.

The annual precipitation, its monthly distribution, and the coefficients of precipitation were read into the computer initially and held constant throughout the study period. The annual precipitation figure and monthly distribution are introduced for each year of the study.

(vii) Pumping - Estimates of volumes of ground water pumped for irrigation and municipal use during the period 1966-1967 were available from the records of the Cherokee Water District. These records included all electric pumps operating in the area. As much as $50 \%$ of irrigation pumping may be accounted for by non-electrically operated pumps. Wherever possible a figure, based on operator's estimate, was introduced to account for this non-electric pumping.

The total volume of ground water pumped from each grid for each year of the study was read into the computer. Coefficients of pumping 
were assigned to each grid to indicate what percent of ground water pumped returned as recharge. The coefficient of pumping is defined as that fraction of ground water not returning to ground water when applied during irrigation, and was set at $70 \%$. In grids where ground water was pumped for municipal use, the coefficient of pumping was set at $100 \%$ to indicate no return to the ground water aquifer.

The monthly distribution of the annual pumping and the coefficients of pumping were read into the computer and held constant for the entire study. Annual pumping volumes for each grid were read into the computer and revised as records indicated for each year of the study. Discussion of Data Accuracy - In order to achieve accurate results from the mathematical model, the data input must be accurate. The following items and discussion indicate possible sources of error.

1. Data sources - It was found in this study that measurements of water levels in wells made by two or more agencies can be significantly different due to the collection process and interpretive procedures. Thus before trying to incorporate data from two or more different data collecting agencies into any study, the collection techniques and interpretive processes of the agencies involved must be evaluated. For example, water table elevations from two sources vary due to differences in the determination of the water table depth, the land surface elevation, and the point location. Additional variations (errors) result when these data are contoured.

2. Water table elevations - When measuring water level elevations in wells it is difficult to ascertain whether the elevation of water in the hole is a result of unconfined, perched, artesian conditions, or some combination of these three. When a map of water level elevations 
combines data points from perched, unconfined and artesian flow systems, contours of these combined levels are meaningless. Flow gradients and saturated thicknesses cannot be accurately determined unless all water levels are taken from a single flow system.

3. Land surface elevations - Since depths to water are measured in the field, it is necessary to know the land surface elevation to determine water level elevations. Land surface elevations are taken in most cases from topographic maps. Insufficient or incomplete topographic coverage and topographic coverage at different scales can introduce a significant error in land surface elevations.

4. Bedrock elevations - The bedrock elevation and water table elevation determine the saturated thickness. Any error in either figure will either increase or decrease estimates of the amount of ground water available. Precise determination of bedrock elevations is difficult due to the possibility of misleading hard "false bedrock" layers and a weathered bedrock surface transition to overlying alluvium.

5. Coefficient of pumping - The coefficient of pumping of 0.70 indicates $70 \%$ of ground water pumped for irrigation does not return to the ground water reservoir. This figure was determined for areas using ditch irrigation. In the Black Squirrel Creek Basin irrigation is by sprinkler systems and the figure of 0.70 could be too low due to high evaporation losses.

6. Permeability - The heterogeneous nature of the alluvium in the Black Squirre1 Creek Basin indicates a wide range of permeability values. The three available pumping tests cover only the upper half of the basin and give poor indication of what actual permeabilities might be expected. Adjusting permeability figures in the mathematical model is 
the easiest way to get a correlation between actual and computed water table elevations. However, such indicated adjustments should be field checked to insure accurate results.

7. Specific yield - The heterogeneous nature of the alluvium in the Black Squirrel Creek Basin affects specific yield just as it does permeability. The figure of 0.20 applied uniformly over the entire study area is at best an approximation based on similar areas and ignores the variable nature of the alluvium to which it applies.

8. Non-electric pumping - Approximately $50 \%$ of irrigation pumping in the Black Squirrel Creek Basin is accounted for by diese1, gasoline, and natural gas powered pumps. Accurate determination of this pumped volume could be a study in itself. Wherever possible farmers and ranchers' estimates of water pumped were used in the mode1. Poor and non-existant estimates make this non-electric pumping figure questionable.

The model result reflects the errors associated with the parameters that are used in the model. However, these potential errors are reduced by introducing average figures for bedrock elevations, water table elevations, and land surface elevations in each grid. In addition, the error introduced by each variable is not necessarily of the same magnitude and significance. A regression analysis is suggested to indicate relative importance of the variable.

To allow for the possible error in the model results a 14 foot acceptability figure is introduced. In this study this is $5 \%$ of the average saturated thickness. At this time, no better statistical means is available to assess the significance of the model results. Current 
research on data optimization for the model will contribute to determining the significance of the model results.

\section{Discussion of Results}

At the end of the 1440 day period (March, 1970) modeled on the computer, the computer prints out final water table elevations for each permeable grid as well as corresponding deviations \pm from the initial water table elevations (1966). Table 2 indicates the difference in each grid between actual and computed water table elevations for 1966-1970. Only discrepancies greater than 4 feet in magnitude and occurring in several adjoining grids were considered to be significant. Inherent errors in the variables included in the model could easily account for an error up to 4 feet, or $5 \%$ of the average saturated thickness. Discrepancies greater than 4 feet in individual isolated grids did not constitute sufficient evidence that some physical influence was affecting the grid and were not considered to be significant anomalies.

Predicted water table elevations higher than the actual 1970 water table elevations were termed positive. Those lower than the 1970 water table elevations were termed negative. Assuming the data were reasonably accurate, a positive discrepancy indicated a loss of water from the system that was not accounted for in the model. The difference between the lower actual 1970 figure and the higher predicted 1970 value represents the surplus of water predicted by the model that was actually lost over the study time per unit area $\left(0.5 \mathrm{mi}^{2} / \mathrm{grid}\right)$. A negative discrepancy would indicate addition of ground water to the system that was not accounted for in the model. 


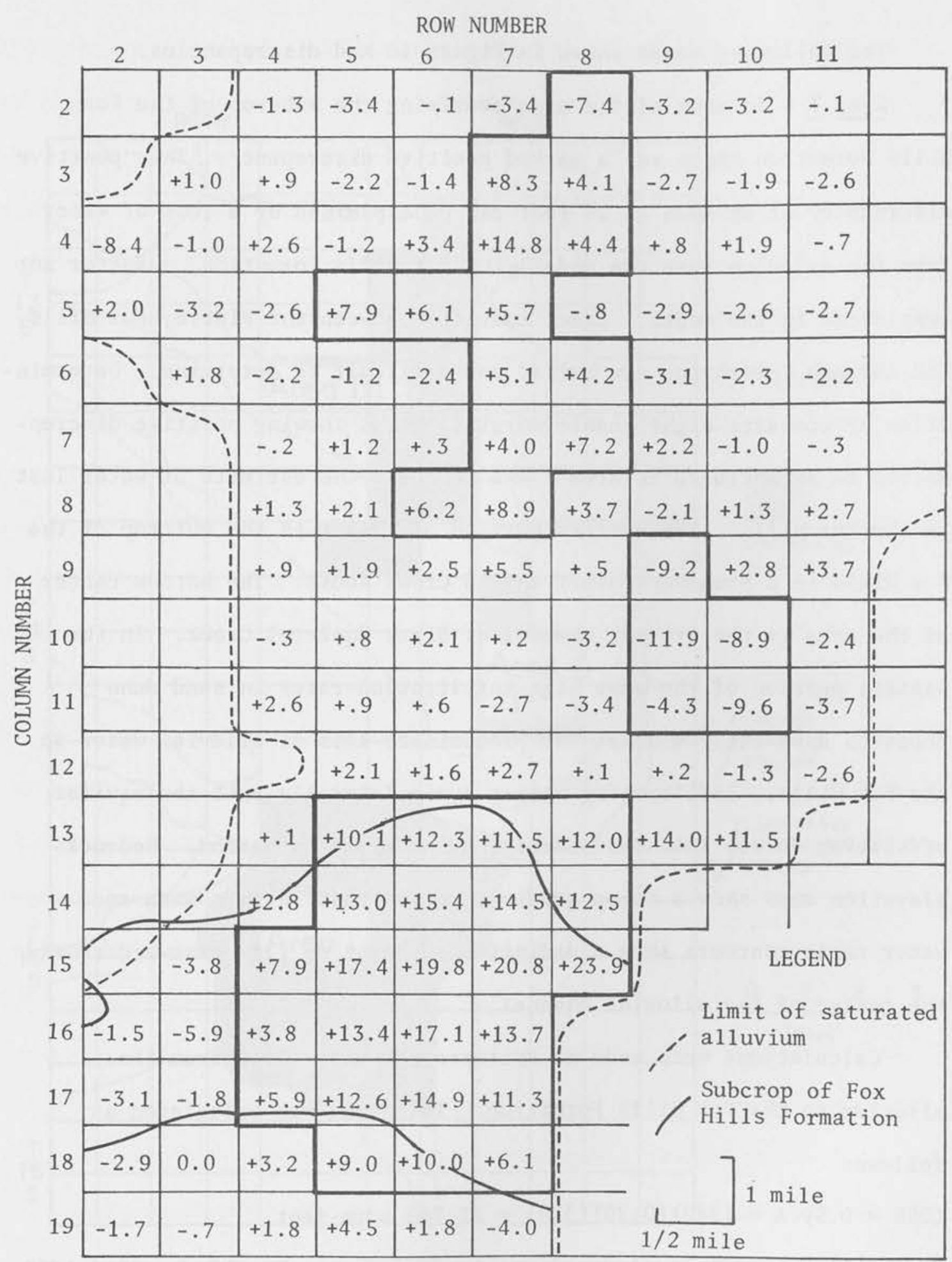

(a) Anomalous areas are outlined.

Table 2. Difference in feet between actual and computed water table elevations in each grid for 1966-1970. 
The following areas shown in figure 16 had discrepancies:

Area I - In most of the area overlying the subcrop of the Fox Hills Formation there was a marked positive discrepancy. This positive discrepancy of as much as 24 feet can be explained by a loss of water from the alluvium into the underlying Fox Hills Formation, a factor not considered in the model. Exact contacts between the Pierre, Fox Hills, and Laramie Formations are buried and difficult to determine. Determination of contacts might enable marginal grids showing positive discrepancies to be included in Area I and increase the estimate of water lost to the Fox Hills. The eastern portion of Area $I$ is the outcrop of the Fox Hills in a prominent bluff called Crows Roost. The bottom center of the area is the present channel of Black Squirrel Creek. In the western portion of the area high infiltration rates in sand dune deposits apparently obscure the predominate loss of alluvial water to the Fox Hills. Infiltrating waters drain laterally into the aquifer offsetting losses into the underlying Fox Hills Formation. Bedrock elevation maps show a steep gradient to the east in this area and water table contours show a definite component of flow eastward toward the center of the alluvial channel.

Calculations were made to estimate the water loss from the alluvium to the Fox Hills Formation. This loss was calculated as follows:

LOSS $=$ D.Sy.A $=(340)(0.20)(320)=21,760$ acre - feet.

Where $\quad D=$ sum of actual drawdowns in feet for each grid for 1966-1970 Sy $=$ specific yield (dimensionless)

$$
A=\text { area of a grid (acres) } .
$$




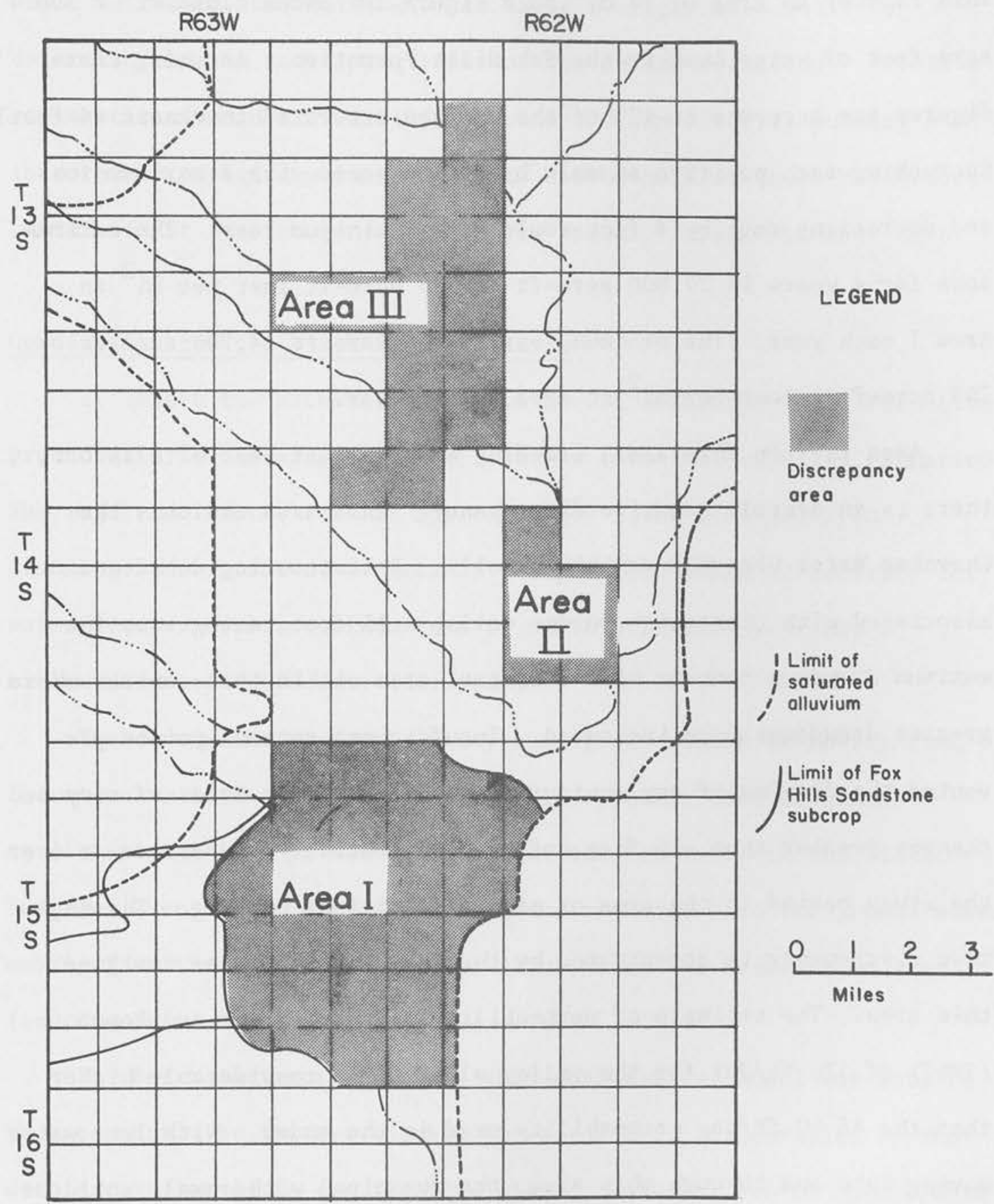

Figure 16. Areas showing discrepancies between computed and actual drawdown. 
The loss of storage over 4 years in the model was 21,800 acre-ft. This is over an area of $14 \mathrm{mi}^{2}$ so a figure for annual $10 \mathrm{ss} / \mathrm{mi}^{2}=390$ acre-feet of water lost to the Fox Hills Formation. Assuming these figures are accurate to $\pm 5 \%$ of the average saturated thickness ( 4 feet), increasing each positive anomaly by 4 feet would give a maximum loss and decreasing each by 4 feet would give a minimum loss. The maximum loss for 4 years is 27,800 acre-ft or 500 acre-ft lost per $\mathrm{mi}^{2}$ in Area I each year. The minimum loss for 4 years is 14,700 acre-ft or 265 acre-feet lost per $\mathrm{mi}^{2}$ in Area I each year.

Area II - In this area, trending N-S and just east of Ellicott, there is an overall negative discrepancy. This area encloses the Cherokee Water District municipal wells. In contouring drawdowns associated with these high volume wells, a 15 foot contour was the maximum drawdown contour with a central area within this contour where greater drawdowns were indicated. Insufficient control points prevented the drawing of any contours beyond -15 feet. Grids of computed changes greater than -15 feet define more precisely the drawdowns over the study period in the area of maximum municipal pumping. The negative discrepancy is accentuated by the low permeabilities assigned this area. The estimate of permeability given by Erker and Romero (1967) of $125 \mathrm{ft} /$ day for the valley alluvium is considerably higher than the 45-60 ft/day permeability used in the model. With less water moving into and through this area, the municipal withdrawals would be greatly accentuated, accounting for the negative anomaly.

Area III - This area shows a general positive discrepancy without well defined boundaries. Time limitations restricted any field investigations to account for this anomalous area. However, the area 
is underlain by the Dawson Formation and water may be lost to it. This would introduce a positive anomaly whose configuration would be determined by the underlying sands of the Dawson Formation. Possible explanations would also include unaccounted non-electric pumping and incorrectly assigned permeabilities. One or both of these parameters could account for the general positive anomaly present in this area.

\section{Conclusions for the Black Squirrel Basin}

1. Where the saturated alluvium overlies the Fox Hills Formation ground water is flowing from the alluvium into the Fox Hills Formation. The magnitude of the 10 s is approximately 5,350 acre-feet/year. Assuming a deviation of \pm 4 feet is the possible range of accuracy for water levels gives a maximum loss of 6,950 acre-feet/year and a minimum loss of 3,600 acre-feet/year.

The conclusion from this study that ground water is moving from the alluvium into the underlying Fox Hills Formation strengthens earlier indications of Kuhn (1968) that the Fox Hills in the Black Squirre1 Creek Basin acts as part of the recharge area for ground water moving from the Fox Hills into the alluvium in the Kiowa-Bijou area (see Figure 6).

2. Before attempting to use this mathematical model the data to be used should be further checked for accuracy. Inaccuracies in the data are reflected in the final solution. Data subject to appreciable error limit the degree of confidence that can be assigned to the resulting values. In this study, anomalies in water levels associated with the Fox Hills subcrop were large enough to be recognized above 
the 4 feet acceptability limits. Had this anomaly been of lesser magnitude the error allowances would have effectively obscured it. 


\section{HIGH PLAINS GROUND WATER BASIN}

The High Plains, in northeast Colorado, became the first designated Ground Water Basin following the enactment of the Colorado Ground Water Management Act of 1965. This Act established the criteria for which a basin may become "designated". Information concerning the geographic boundaries of the basin, the size, shape and water-storing characteristics of all aquifers within the basin, the annual recharge to these aquifers, and the present and projected withdrawals from these aquifers is necessary for the establishment of a designated ground water basin.

\section{Description of Problem}

Since previous investigations have considered bedrock units, i.e., White River Group and Pierre Shale, within the High Plains to be impermeable, no appreciable amount of ground water was thought to be diverted from the basin through bedrock units.

Redde11 (1967) was first to draw attention to the possibility of substantial subsurface ground water loss to bedrock units within the High Plains Ground Water Basin. In investigating the distribution of ground water recharge in the High Plains, Reddell assumed that the bedrock units were impermeable. As a result of his study, Reddell discovered a negative recharge area, i.e., a natural subsurface discharge area, trending in a northeasterly direction (see Figure 17). Reddel1 concluded that the presence of the negative recharge area placed suspicion on the initial assumption that the bedrock units are impermeable.

If ground water discharges into underlying bedrock units as Redde11 suspects, then ground water may also be diverted from the High Plains Basin north to the South Platte River. Water diversion through 

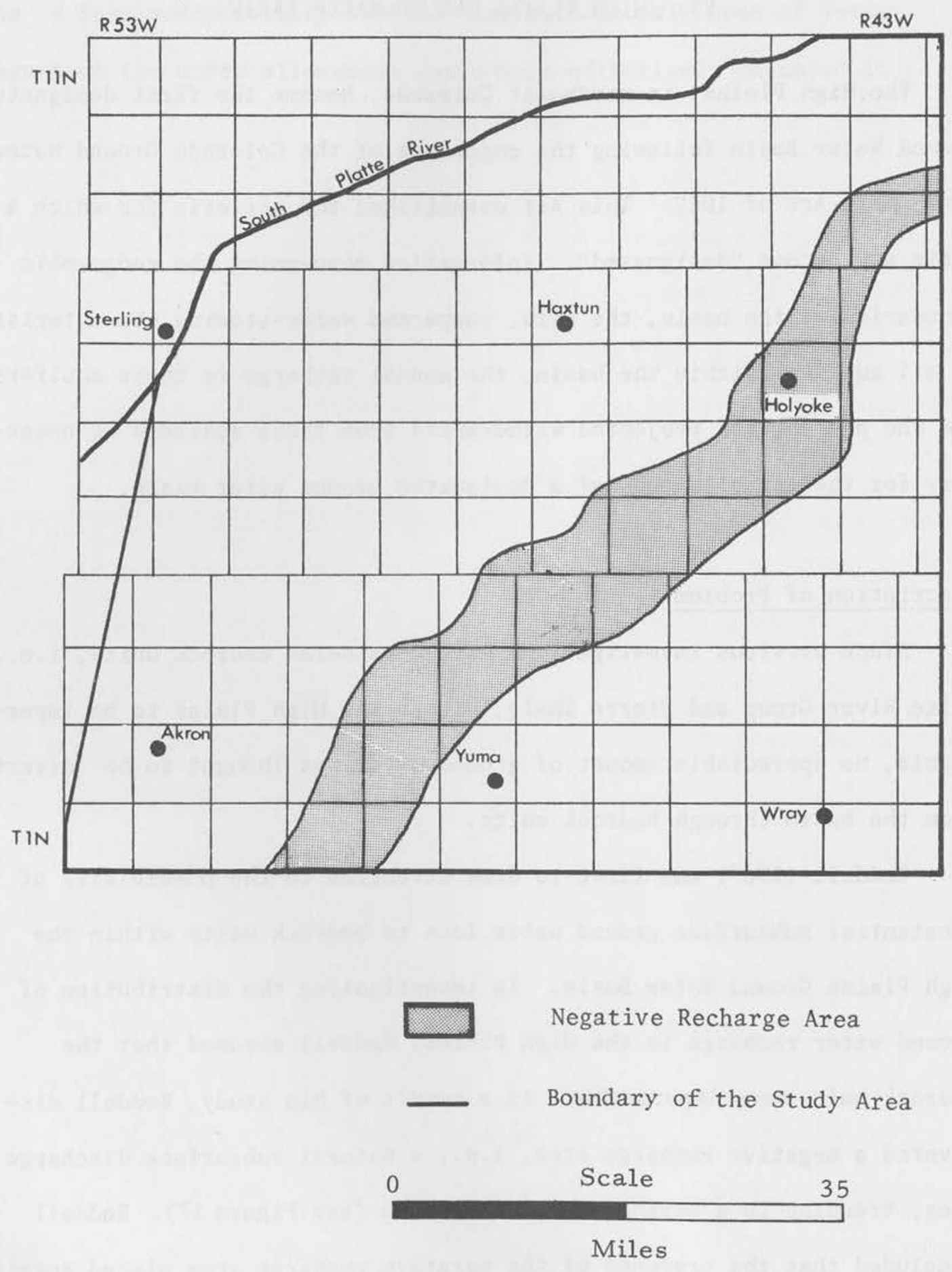

Figure 17. Reddell's negative recharge area in the High Plains. 
bedrock units is of interest since this potential loss from the basin has not been accounted for in previous ground water management studies of the High Plains.

Method of Calculating Net Recharge

Before development, the groundwater in the Ogallala Formation is assumed to have been in a state of dynamic equilibrium. This means that the average recharge was balanced by an equal amount of natural discharge, and these in turn determined the rate of groundwater flow. Hence, by determining the rate of groundwater flow, the rate of recharge can be estimated. This would appear to be the most logical approach since the slow movement of groundwater tends to average out the effects of unequal recharge rates of short duration at different times.

Assuming dynamic equilibrium, a finite difference approach was used to evaluate the natural recharge rates necessary to maintain the groundwater gradient in a steady state prior to development. The steady state form of the Boussinesq equation was written in finite difference form and a solution for the recharge rate obtained on the digital computer. This model is the steady-state portion of the mathematical model described in Section II.

Net Natura1 Discharge Along a Line from Southeastern Sedgwick County to 18 Miles South of Akron

Results from the numerical method indicated that there is a loss of about 75,000 acre-feet of groundwater per year which occurs in the area shown in figure 18. Field investigation revealed no surface discharge and pumping by wells in the area, especially prior to large scale development, is not enough to account for such a large amount of discharge. 
Upon studying the subsurface geology of this area, it was found that this narrow discharge area compares closely with the approximate subsurface extent of the White River Group. Figure 18 was prepared to whos this relationship. The White River Group contains small amounts of water in hydraulic connection with the Ogallala Formation. Several wells in the area have been noted to penetrate sand layers in the White River Group. If such a sand member could be stratigraphically located over the entire area, then it seems possible that water is moving from the Ogallala Formation laterally into the White River Group and down gradient in the White River Group to the South Platte River. The north-south geologic cross section of figure 19 running northward from the discharge area to the South Platte River illustrates this hypothesis. If this is a subsurface discharge area, it should be noted that the actual amount of subsurface discharge will be larger than the calculated 75,000 acrefeet per year. This is because of the breakdown in the assumption that the lower boundary is impermeable. Section VIII presents a more detailed description of geologic conditions influencing this water transfer from the High Plains to the South Platte. 


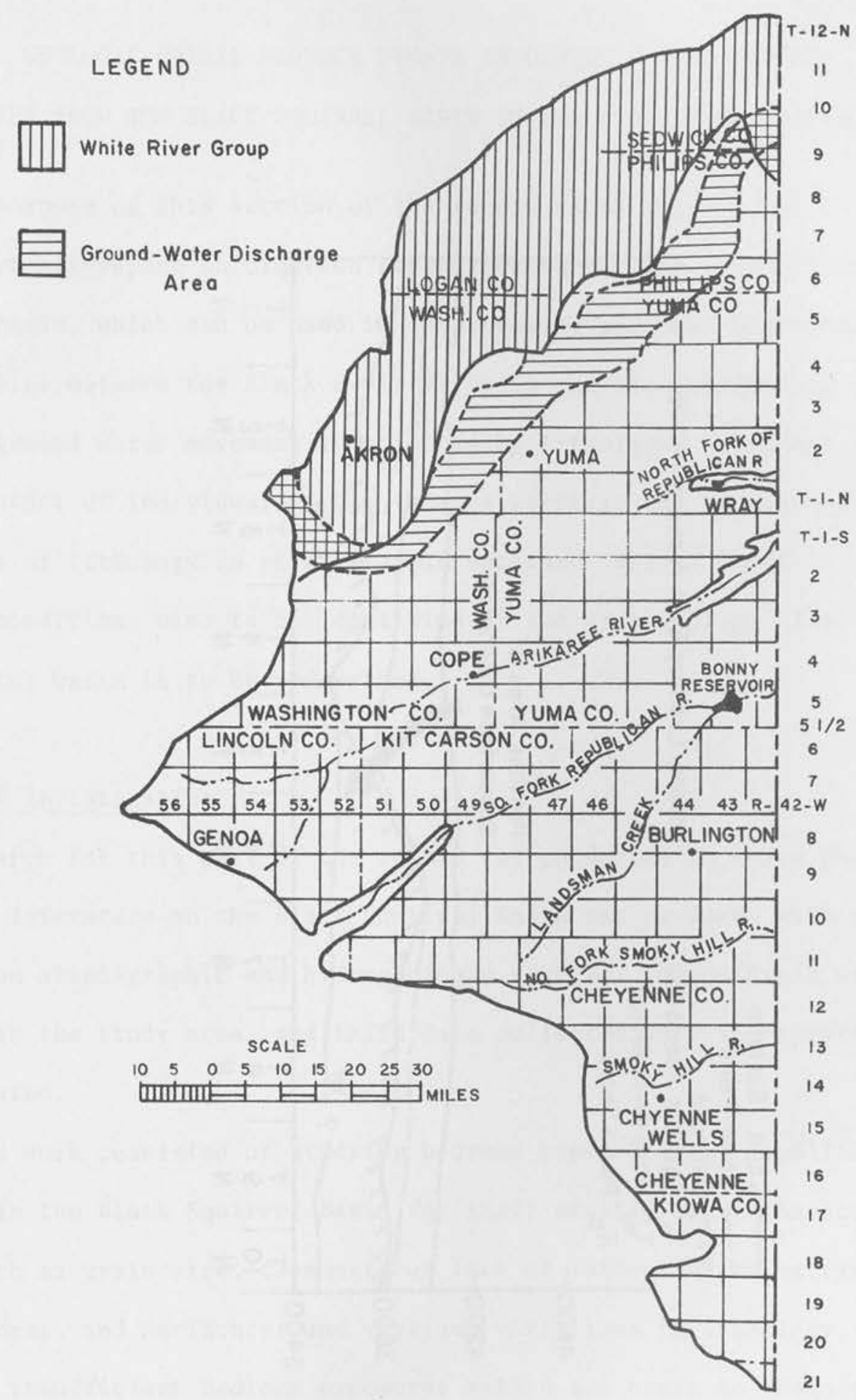

Figure 18. Relation between subsurface extent of the White River Group and a major groundwater discharge area. 


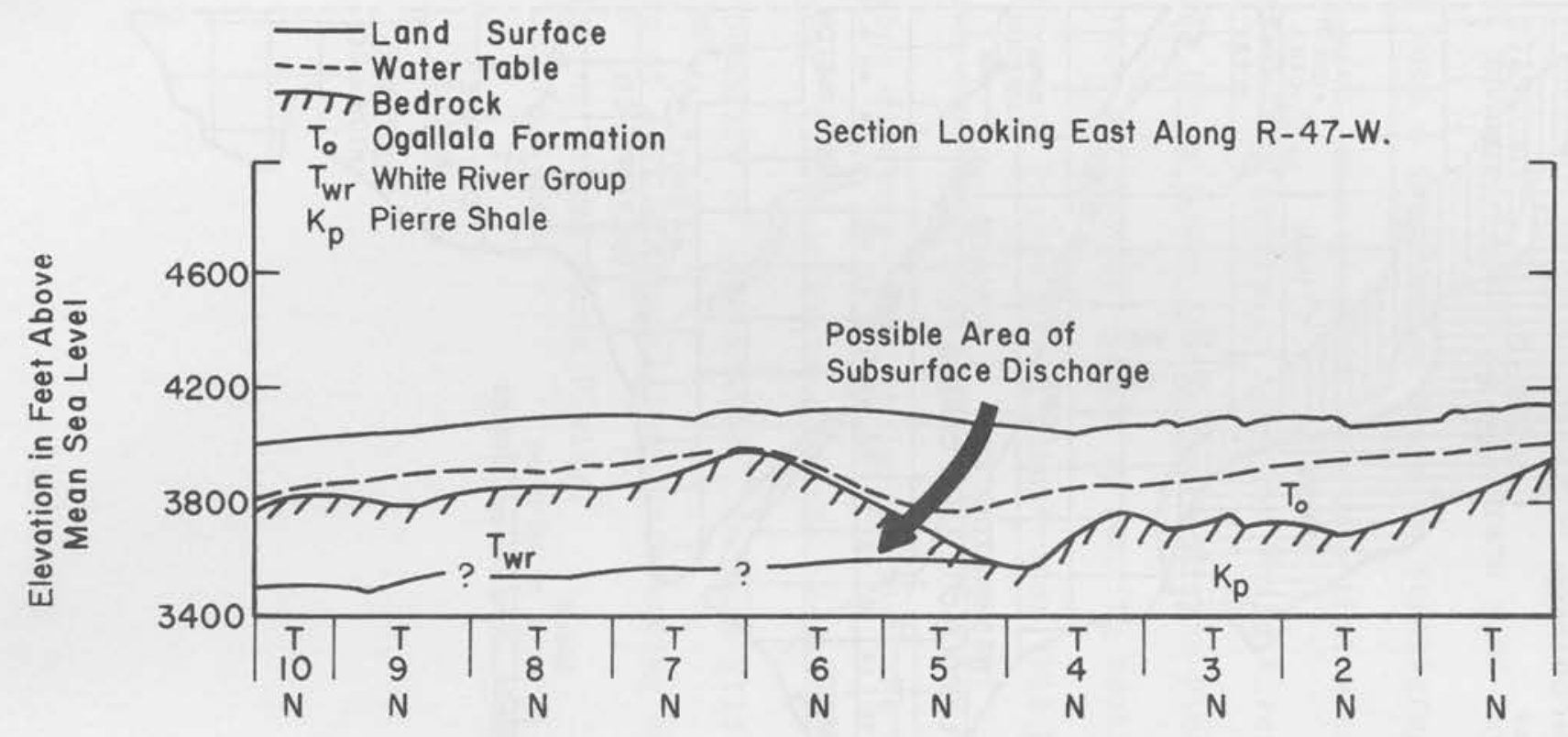

Figure 19. Geologic cross section of the northern part of the Northern High Plains indicating a hypothetical possibility for subsurface discharge from the Ogallala Formation into the White River Group. 
VII. GEOLOGIC DETAIL-BEDROCK STRATA INVOLVED IN GROUNDWATER

TRANSFER FROM THE BLACK SQUIRREL BASIN TO THE KIOWA-BIJOU BASIN

The purpose of this section of the report is to present more detailed stratigraphic information on bedrock formations in the Black Squirrel Basin, which can be used in interpreting regional hydrogeologic relationships between the Black Squirrel Basin and the surrounding area. Regional ground water movement is affected by lithology, thickness and lateral extent of individual strata, and by vertical and horizontal variations of lithology in stratigraphic section. All of these geologic conditions need to be identified if the hydrogeology of a ground water basin is to be understood.

Methods of Investigation

Research for this part of the report was conducted in three phases: first the literature on the Black Squirrel Basin was reviewed with special emphasis on stratigraphic and hydrogeologic studies; second field work was done in the study area; and third data collected were interpreted and evaluated.

Field work consisted of studying bedrock exposures and regolith deposits in the Black Squirrel Basin for their stratigraphic characteristics such as grain size, cleanness or lack of intergranular matrix, bed thickness, and horizontal and vertical variations in lithology. There are insufficient bedrock exposures within the basin to adequately evaluate the stratigraphic properties of the individual formations, therefore outcrops of these same units were sought in the surrounding areas to the east, north, and west where they were known to be present within the Denver Basin. Major exposures of the Dawson, Laramie, Fox 
Hills, and Pierre Shale Formations were observed in the Hanover Northwest Quadrangle just west of the study area. After locating and studying outcrops in the areas surrounding the Drainage Basin, exposures were sought in regions further from the area of immediate interest. This resulted in observations in the vicinity of the U. S. Air Force Academy, along the front of the Rampart Range, and at Austin and Popes Bluffs in Colorado Springs. A11 exposures studied were 10 to 20 miles west of the study area, along the southwestern edge of the Denver Basin.

Due to the lack of good bedrock exposures within the Black Squirre1 Basin, attention was turned to geophysical oil well logs for further information on subsurface conditions within the basin. Also, geological and geophysical well logs of deep water wells in the area were collected for study.

The final phase of the study involved interpreting the data collected, which resulted in the information and conclusions contained in this report. Bedrock exposures of the various formations of interest in and surrounding the basin were correlated with geophysical logs of wells within the basin which had recorded the same units. Geophysica1 We11 Logs

Geophysical well logs have proved invaluable in interpreting the distribution, thickness, and stratigraphic properties of bedrock formations in the Black Squirrel Basin. Subsurface geophysical methods were of special value because of the general lack of surface exposures of bedrock units within the basin. Geophysical logs of wells drilled in the area generally provide records which include the entire section of geologic formations in the area. The oil well logs studied were standard electric and induction electric logs, consisting of spontaneous potential and resistivity traces. 
The distribution of oil well logs used in shown in figure 20. Wells are numbered for identification in $10 \mathrm{~g}$ correlations shown later in the text. The locations of these log correlations, and the logs used are also shown in figure 20 Generally, the top 230 to 250 feet of the oil we1ls are not logged due to the presence of steel casing in the wells.

Interpretation - The SP and short and long normal resistivity traces shown on the logs are used in conjunction to identify the major stratigraphic units. The SP curve increases in positive value from left to right. High positive values are indicative of shale units when accompanied by corresponding low resistance values for both the short and long normal resistivity curves. Negative values are indicative of sandstone units. Where holes are filled with non-conductuve muds, or the resistivities of both mud filtrate and formation water are about equal, the SP curve deflections will be small and the curve will be rather featureless. In this case the shale and sand interpretations are not always possible.

The short and long normal resistivity curves are used in conjunction to estimate the effective porosity in any given rock unit. This effective porosity is the "usable porosity," or the pore space which is capable of transmitting fluids through the rock. This is in contrast to the isolated pore spaces and the interconnected pore spaces, which are too small to transmit fluids easily. As a general rule, the wider the separation between the short and long normal curves the greater the effective porosity thus the greater the permeability. This is only valid where there is a distinct difference between the salinity of the drilling fluid and the salinity of the formation fluid. 


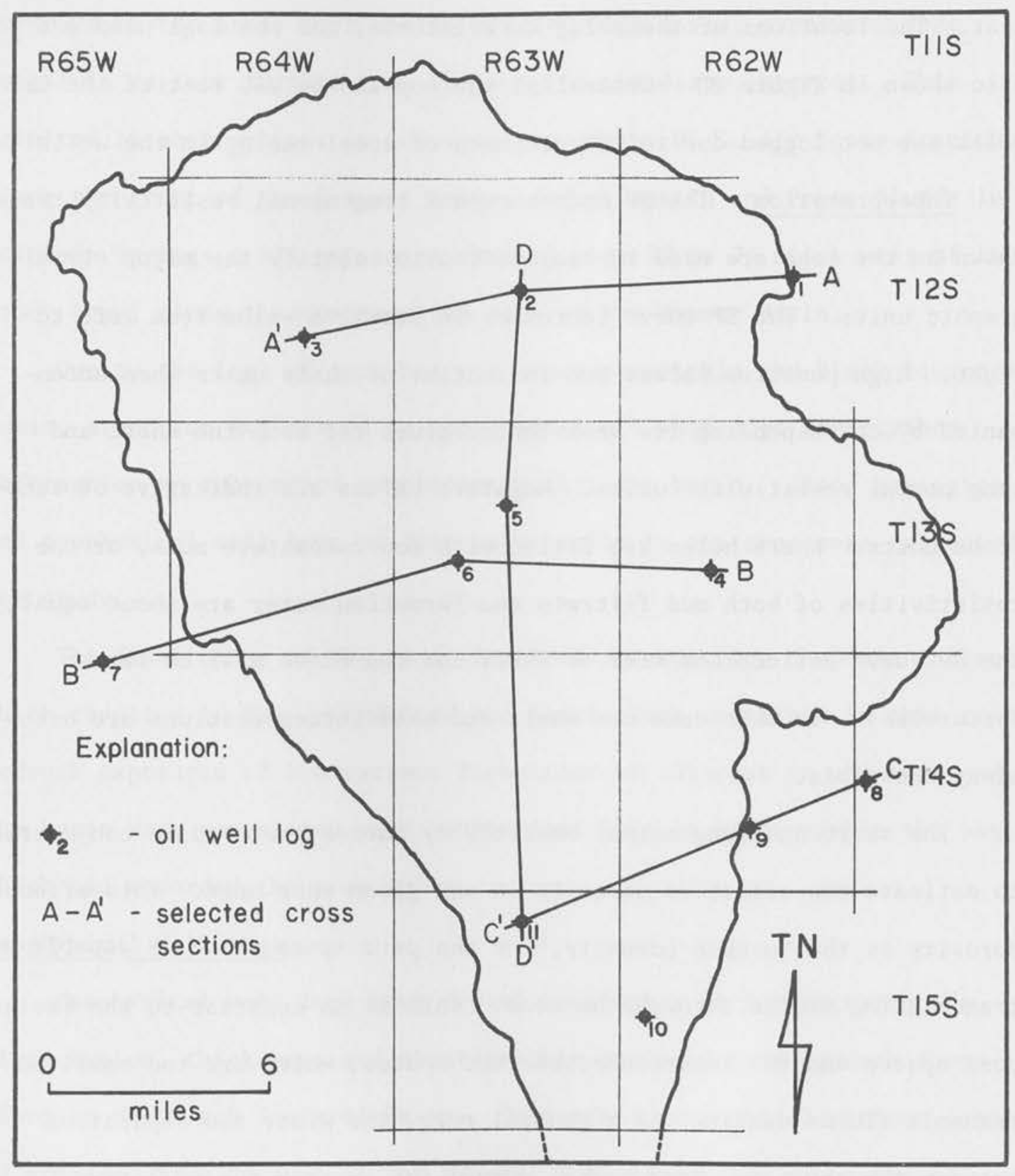

Figure 20. Distribution of geophysical well $\log$ s with selected $\log$ correlations in the Black Squirrel Basin. 
From the logs used in this study, $\log$ number 1, "R. W. Lewis," has been selected as a representative electric log of the major formational units located in the Black Squirrel Basin. This $\log$ is shown in figure 21. It has been reduced $40 \%$ in scale from the commercial $10 \mathrm{~g}$, and has the interpreted contacts of the major stratigraphic units marked. Thicknesses shown on the $\log$ for these units are only valid at the location of the bore hole.

Beginning at the bottom of the $\log$, the following observations can be made from the electric $\log$ in figure 21. The Pierre Shale section consists of alternating sandstone and shale in the $\mathrm{Kp}$ member and grades rapidly downward into continuous shale (only the uppermost part of this section is actually shown on the $10 \mathrm{~g}$ ). Overlying this is the basal sandstone member of the transition zone, designated as Kps. This is a thick sequence of sandstone interbedded by thin shale strinager, and is easily identified on most geophysical well logs from the study area. On most logs, this basal sandstone shows greater separation between the short and long normal resistivity traces than the upper part of the transition zone. This indicates a higher degree of permeability for the basal sandstone than for the rest of the transition zone. The upper part of the transition zone, designated Kpt, is generally thicker than the basal sandstone. It consists of alternating silty sandstones and shales, with the shales predominating. The silty sandstones show narrow separations between the short and long normal resistivity traces. This is indicative of lower permeability relative to the basal sandstone.

The basal sandstone of the transition zone contains water with a relatively high amount of dissolved solids as shown by the reversal on the resistivity traces. This is indicative of a zone of poor quality 


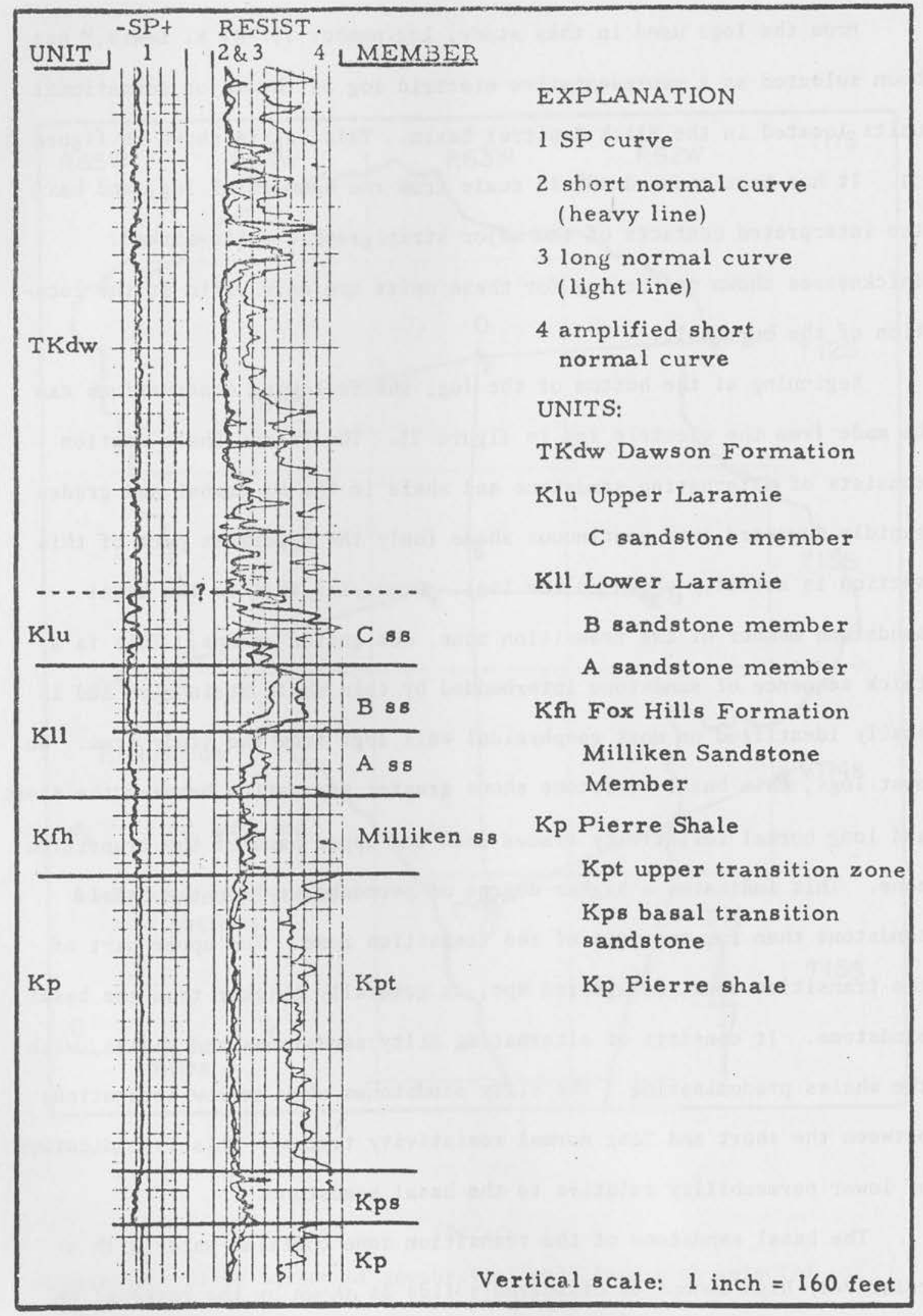

Figure 21. Typical electric log from Black Squirrel Basin. 
water compared to the other water bearing sandstones on the $10 \mathrm{~g}$ such as the Fox Hills and the A and B sandstones of the Lower Laramie. This indication is verified by McLaghlin's work (1946) in which he states that water in the Pierre Shale is of very poor quality and is unsuitable for many uses. Outcrops of the transition zone observed in the field contained abundant selenite gypsum. Solution of this mineral by ground water could account in part for the dissolved salts in the formation water.

The next unit overlying the transition zone is the Milliken Sandstone Member of the Fox Hills Formation, designated on the $\log$ as Kfh. This unit shows up on the $\log$ as interbedded sandstone and shale. The greater degree of separation between the short and long normal resistivity curves indicates a higher permeability for the Milliken than for the underlying sands of the transition zone. Abundant spheroidal concretions up to five feet in width have been observed in outcrops of the Milliken Sandstone in the study area. Where drilled through, these concretions may account for considerably different patterns on the electric logs produced from the unit.

The lower contact of the Milliken Sandstone can be taken as that zone on the log below which the section is predominantly sandy shales and shales. The lower contact is transitional and thus not always readily distinguished on the logs. The upper contact of the Milliken is also indistinct, but is more readily determined since the massive A sandstone is the overlying unit. This constitutes a distinct change in the lithology between the underlying interbedded sandstone and shale of the Milliken, and the overlying A sandstone. This upper contact can be distinguished on most logs as the point at which the overlying massive-bedded A sandstone terminates at the top of the shale bearing Milliken unit (figure 21). 
Above the Milliken are the two massive A and B sandstone units of the Lower Laramie Member. They are easily identified and distinguished on the electric logs and taken together make up the most readily identifiable unit. The top of the B sand is characterized by the presence of a sandstone zone which shows a very distinctive high resistance deflection on the resistivity curve. This deflection, coupled with the presence of the massive-bedded underlying A and B sandstones serves as an excellent stratigraphic marker on the logs.

The two sandstone units are separated by an intervening sandy shale which can usually be delineated on the electric logs. As evidenced by their occurrence on the logs, and the high resistance values recorded between the short and long normal traces, these two units are very continuous, and uniform in lithology throughout the basin. They also may be of greater permeability than the other major units in the basin, as indicated by wide separation of the short and long normal curves.

Above the B sandstone is the Upper Laramie Member. The Upper Laramie is made up of a series of sandstone, shale, and coal beds. Earlier workers in the area (Erker and Romero 1967, Soister 1968, McLaughlin 1946, and McGovern and Jenkins 1966) disagree on the thickness of the Upper Laramie. As shown by the logs from the area, the upper boundary is transitional and, as in the case of the Milliken Sandstone, cannot be readily detected.

Although the upper contact of the unit is not easily determined, the interval comprising the Upper Laramie can be recognized on the logs by noting the location of the top of the B sandstone unit below, and then observing the zone immediately above. The deflections of the electric $\log$ traces for this zone are more varied and intense than for the underlying A and B sands and the overlying Dawson Formation. Often, narrow 
high deflections can be observed on the resistivity curves. These are the coal beds of the unit which often range up to 10 feet or more in thickness as reported by Soister (1968). There is also a thick sandstone bed know as the C sand located near the top of the Upper Laramie unit. It is represented on the logs by a high resistance value, and is reported to lie 30 to 60 feet above the top of the B sandstone (Kuhn, 1968). Deflections occur on many of the logs which may be interpreted as this sand, but are absent on the remaining logs. It is believed that this unit is discontinuous, and thus its actual distribution throughout the study area is uncertain.

The uppermost bedrock unit in the area is the Dawson Formation. A high degree of horizontal and vertical variability is displayed by the Dawson on the electric logs. The formation consists of massive-bedded sandstones, siltstones, shales, and minor discontinuous coals and peats. These lithologic variations in sandstone, shale, and shaley-sand are shown in the logs. The narrow separations for the resistivity traces indicates low permeability for many of the sandstone units in the formation.

Extensive exposures of the Dawson were studied along the western drainage divide of the Black Squirre1 Basin. These exposures display the same type of lateral and vertical variability which the electric logs show for the formation. The outcrops are characterized by massive crossbedded channel fill sandstones, silty sandstones, and argillaceous shales. The channel sands are lenticular. Figure 22 shows two measured sections taken at the Corral Bluffs outcrops along the western edge of the study area. They are within one-half mile of each other and are corrected for relative ground level elevation. The lack of lateral continuity of specific units is shown by these sections. They are believed to be generally representative of the type of deposits within the Dawson. 


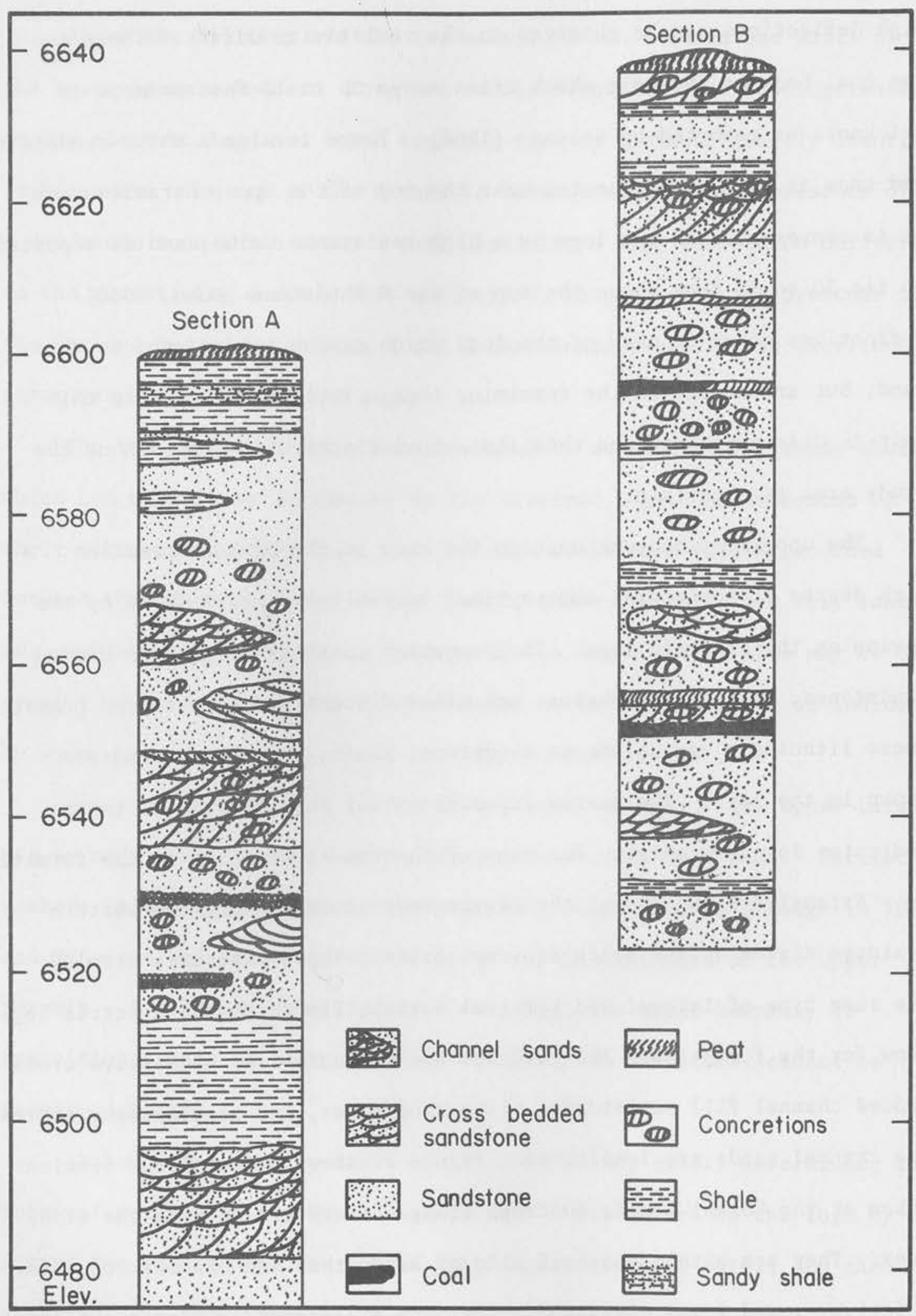

Figure 22. Measured sections from Corral Bluffs outcrop. Section A: T14S R64W Sec. 8. Section B: T14S R64W Sec. 5. 
In the report by Varnes and Scott (1967) on the U. S. Air Force Academy, it is stated that the Dawson Formation is a "multi-aquifer" formation, and is typically composed of alternating beds of fine to very coarse grained arkosic sandstone, variegated claystone, siltstone, and shale. The beds are lenticular and differ in thickness and areal extent. Thus correlation of individual beds by use of drillers or electric logs over long distances is seldom possible. This lithologic variation is well displayed at the Corral Bluffs outcrops, and the lack of correlatability of units in the Dawson is readily seen in the logs from the Black Squirre1 Basin (figures 23 and 24).

Many of the shales observed in field outcrops of the Dawson are highly argillaceous. These shales when wet are of medium plasticity, and where present should serve as definite barriers to downward migration of ground water in the study area.

Application - The following log correlations have been constructed between selected logs to better illustrate the stratigraphic and litho$\operatorname{logic}$ continuity of the various formations within the study area. Locations of the logs used in their construction are shown in figure 20. Log correlations are identified by letter designation, and individual wells are numbered. A11 logs are reduced $40 \%$ in scale from the commercial logs, and are vertically aligned using the top of the B sandstone of the Lower Laramie Member as a locat datum elevation. This unit was chosen, instead of sea level, in order to show maximum exposures of the logs by avoiding adjustment of each $\log$ for relative ground level elevation.

Log correlation A-A' - The first of these log correlations, $\mathrm{A}^{-\mathrm{A}^{\prime}}$, is shown in figure 25. The wells which these logs represent are all in the northern part of the basin. Only the Laramie and Dawson 


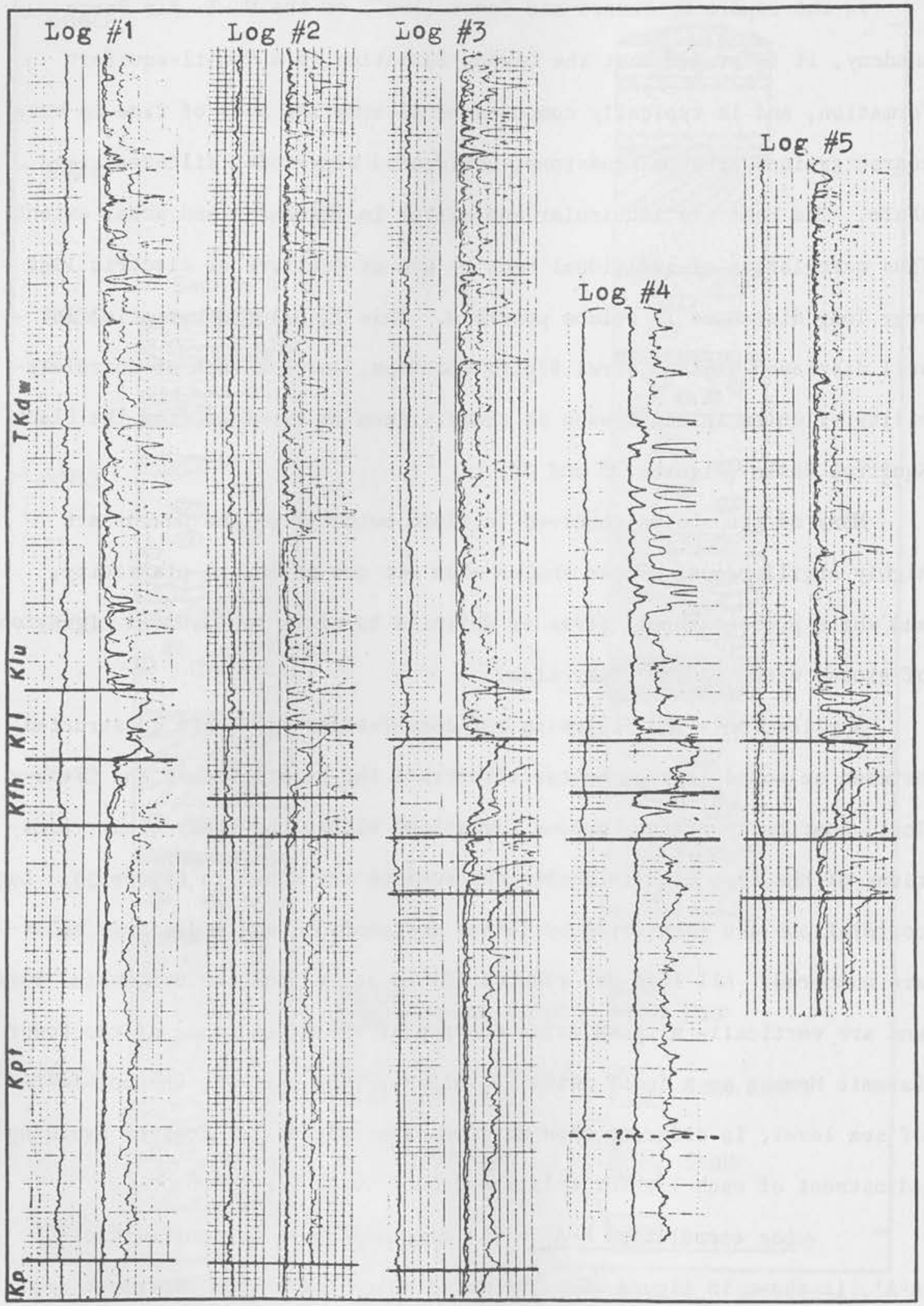

Figure 23. Commercial oil well logs. See figure 19 for locations and figure 20 for formation designations. 


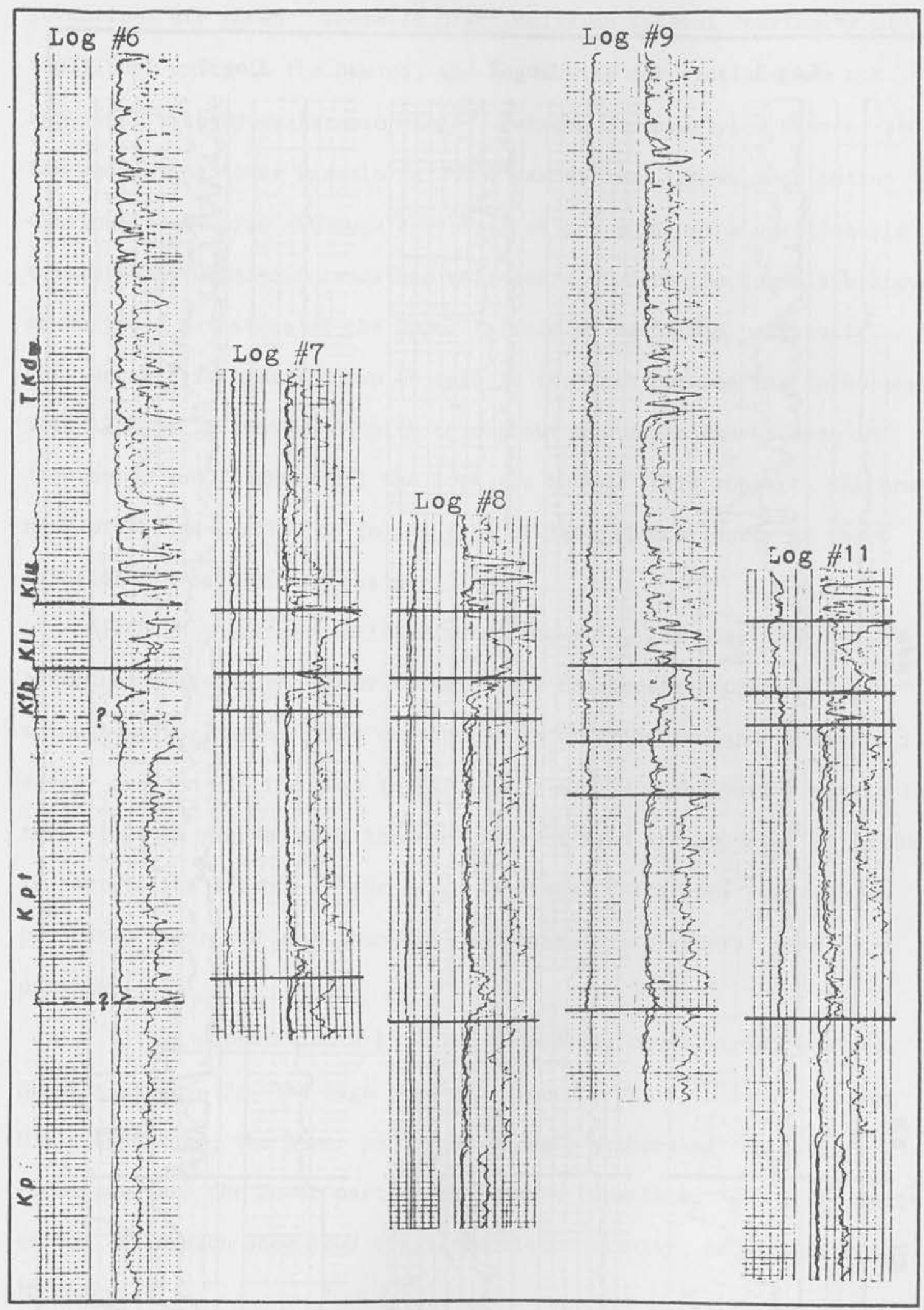

Figure 24. Commercial oil well logs. See figure 19 for locations and figure 20 for formation designations. 


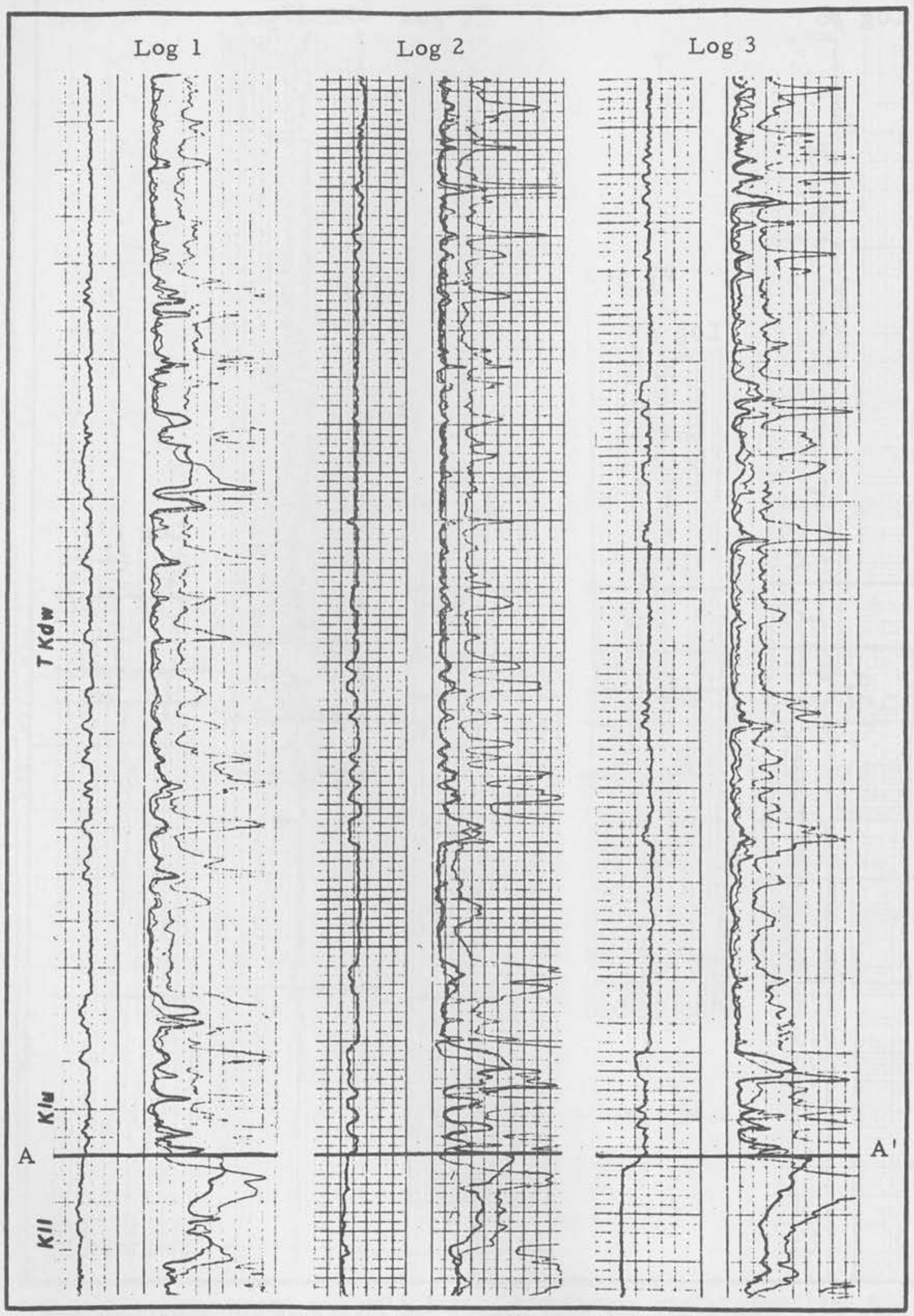

Figure 25. Log correlation $A-A^{\prime}$. See figure 21 for formation symbols. Also figure 20 for cross-section location. 
formations are shown. There is practically no lateral continuity of indifidual units in the Dawson, and $\log$-to-log correlations are not apparent. The Upper Laramie Member, between the overlying Dawson, and the underlying Lower Laramie (A and B sandstones), shows much better continuity of units although correlations are still of a questionable nature. The uppermost sandstone unit correlated on the logs is believed to be the C sandstone of the Upper Laramie as mentioned previously. Considerable variability can be seen in the unit between the three logs. This lack of lateral continuity throughout the basin can be seen in figures 23 and 24 where all the logs are shown. This supports the premise presented earlier as to the lack of lateral continuity of the $\mathrm{C}$ sandstone throughout the basin.

Although there are variations in thickness, the massive A and B sandstone units of the Lower Laramie show the greatest continuity throughout the basin. This continuity in distribution and thickness is easily seen on all the logs in figures 23 and 24 . The variations in the three logs in figure 20 at the top of the A sand are believed to be due in part to the effects of the large flattened calcareous concretions present. These are very abundant, and range up to several feet in diameter.

$$
\text { Log correlation B-B' - The second } 10 \mathrm{~g} \text { correlation, B-B', is }
$$

Shown in figure 26 . The logs show the Pierre transition zone, the Fox Hills Sandstone, the Lower and Upper Laramie Members of the Laramie Formation, and the lower part of the Dawson Formation. All major units except the Dawson show good stratigraphic continuity, and consistent thickness. 


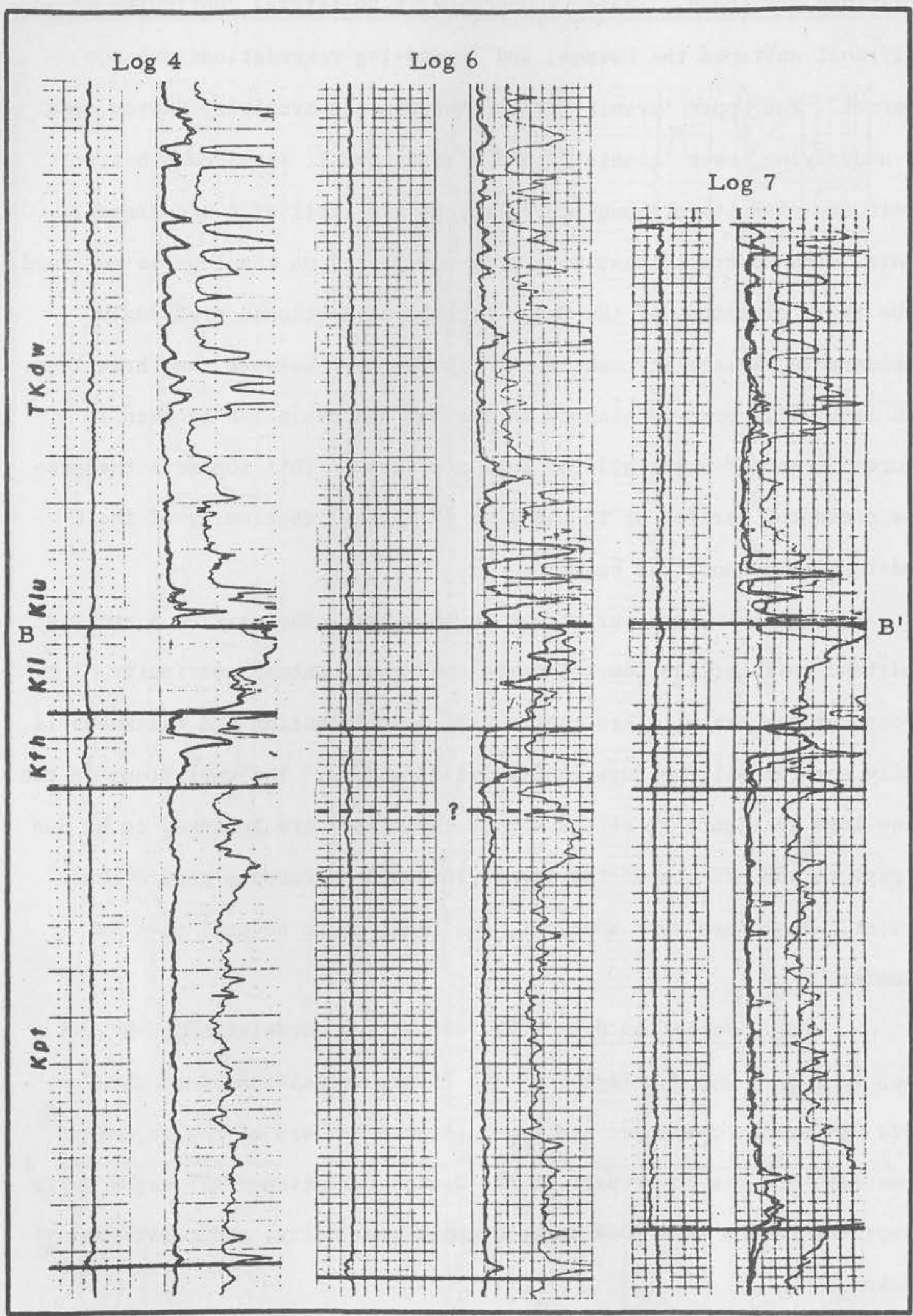

Figure 26. Log correlation B-B'. See figure 21 for formation symbols. Also figure 20 for cross-section location. 
At the bottom of the section is the basal sandstone of the Pierre transition zone. It is best displayed on $\log \# 7$, but can be recognized on the other logs without difficulty. It is well defined on most of the logs throughout the basin as seen in figures 23 and 24 . The transition zone itself is fairly thick and shows the characteristic alternation of sandstone and shale. This is better displayed on the logs in figures 23 and 24 .

The boundaries of the Fox Hills on these logs are not distinct, but through comparison with the other logs in the basin the boundaries are determined with considerable certainty. The lower Fox Hills boundary on $\log \# 6$ is not easily determined and appears to be transitional. The location of this transition zone contact as shown on the $10 \mathrm{~g}$ has been determined through log correlations, and calculated stratigraphic thicknesses for the unit.

Atain, the most easily identified units on the logs are the combined A and B sandstones of the Lower Laramie. They show the most consistent thickness, horizontal continuity, and appear to have the highest permeability of the bedrock units in the basin.

As seen in figure 28, correlations of individual beds in the Upper Laramie are questionable, and correlations of strata within the Dawson section are not apparent. Logs 4 and 6 record the same stratigraphic section of the Dawson Formation as can be seen in exposures at Corral Bluffs. These logs confirm the discontinuity and variability of Dawson strata beneath the Black Squirrel Basin.

Log correlation C-C' - The third and most southerly east-west $\log$ correlation is shown in figure $27\left(\mathrm{C}-\mathrm{C}^{\prime}\right)$. The correlatibility of units as displayed in the previous cross sections is again shown here. 


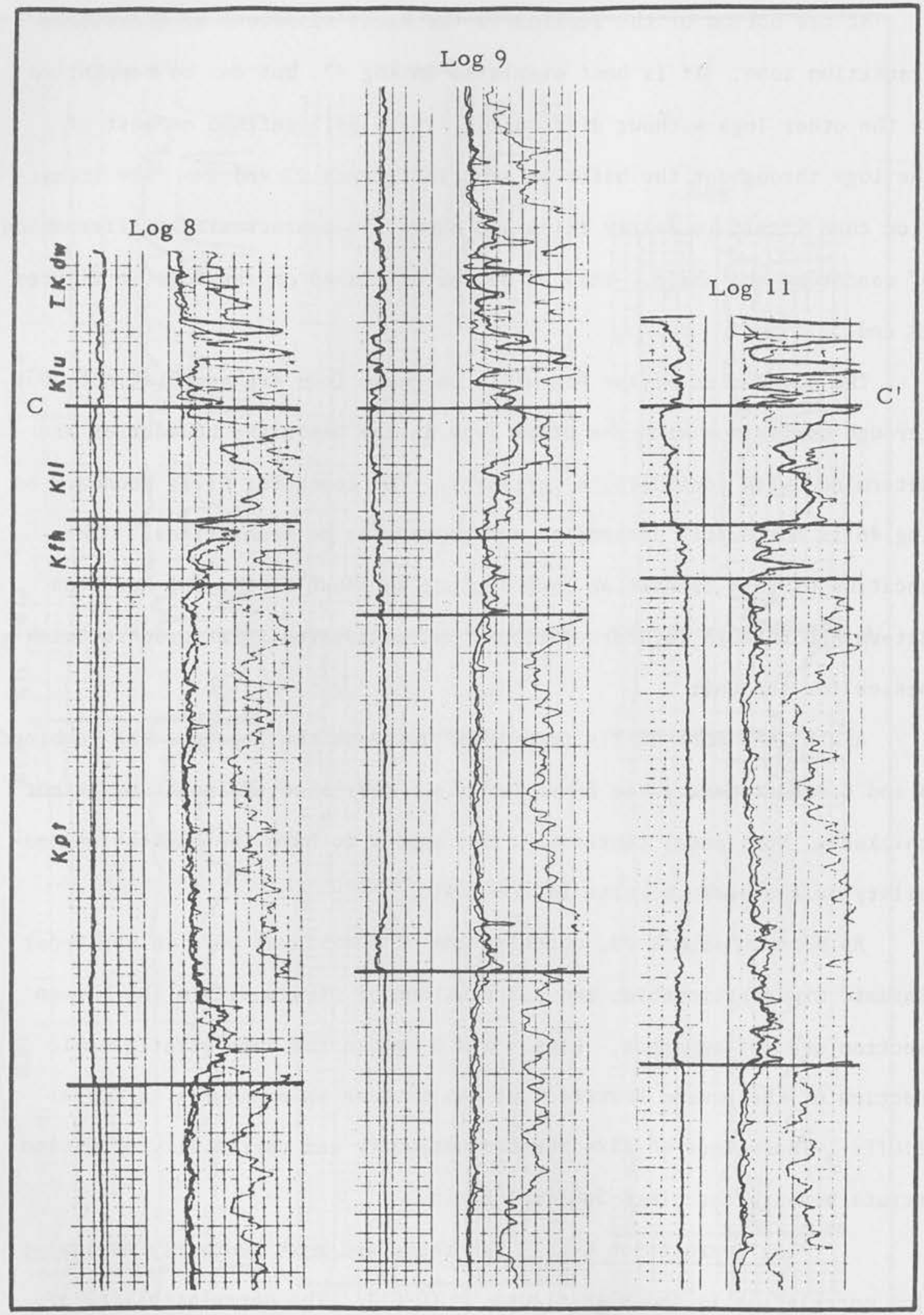

Figure 27. Log correlation C-C'. See figure 21 for formation symbols. Also figure 20 for cross-section location. 
An insufficient section of Dawson is shown on the logs to evaluate its lithologic variability. This is due in part to the fact that the Dawson is much thinner in the southern part of the basin.

There is considerable difference in the thickness of the Pierre transition between $\log 9$ and $\operatorname{logs} 8$ and 11 . The basal sandstone zone is well displayed on all three logs, and the alternating sandstone-shale nature of the transition zone is apparent. The A and B sandstones of the Lower Laramie, and the Fox Hills Sandstone units are again easily identified. Sandstone units in the Upper Laramie are not readily correlatible.

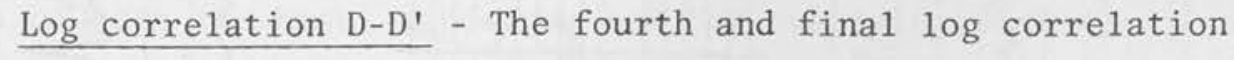
D-D' runs north-south across the basin, and is shown in figure 28. The major units on the logs have much the same characteristics as before as to lateral continuity and individual distinction.

The bottom of the Pierre transition zone is not positively identifiable on $\log \# 5$. It is distinct on $\operatorname{logs} 2$ and 11 , and in comparing the three logs, it can be seen that the transition zone thickens northward into the Denver Basin. The direction of the cross section is very close to the regional dip direction of the bedrock units, thus the logs indicate the conditions as you move down dip to the north out of the Black Squirre1 Basin.

The section containing the Fox Hills, and A and B sandstones of the Lower Laramie is considerably thicker on $\log 5$ than on $\operatorname{logs} 2$ and 11 . The lateral continuity of these units across the basin is well displayed. The lateral variability of sandstone units in the Upper Laramie is well displayed on the logs moving from south to north across the basin. 


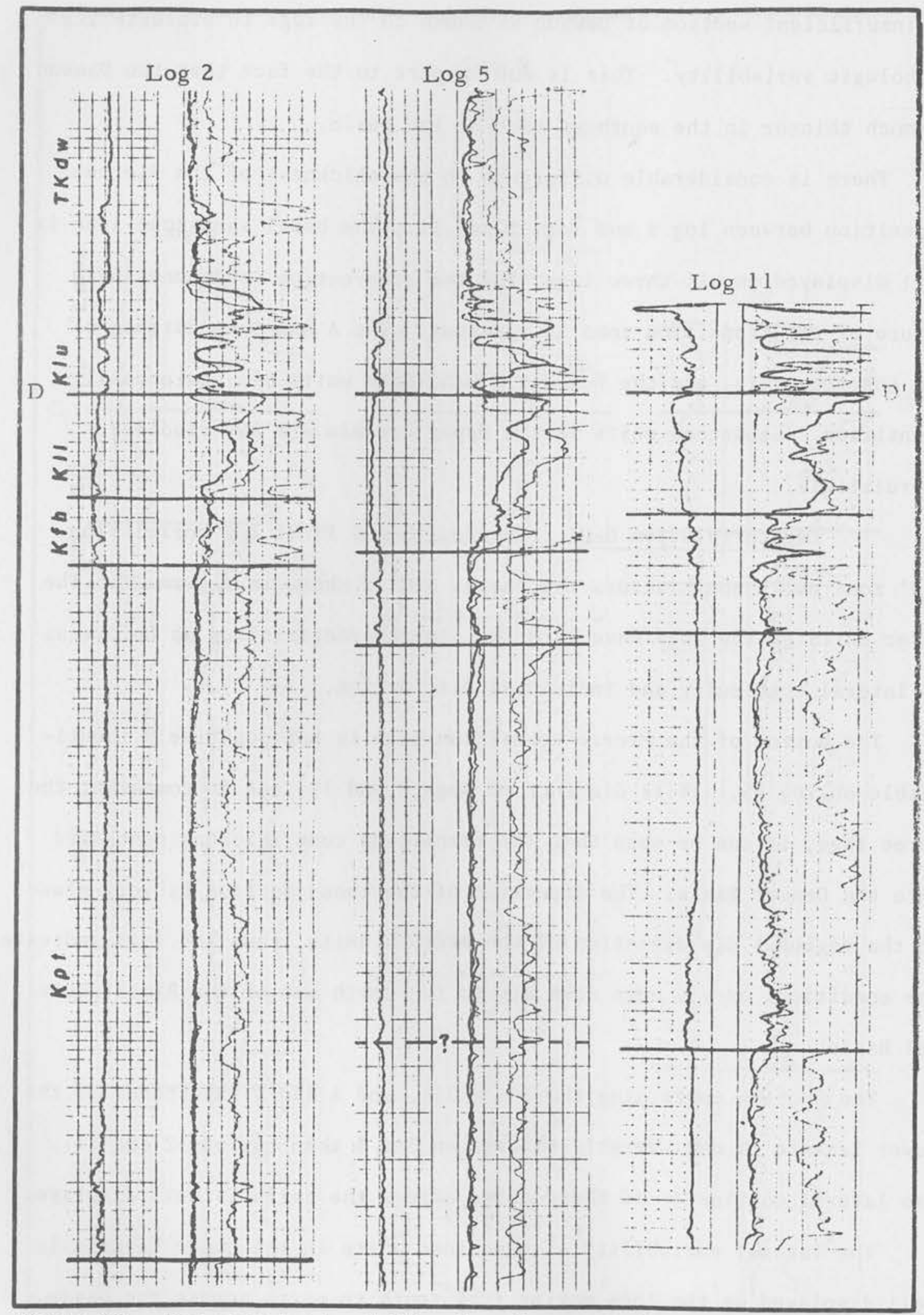

Figure 28. Log correlation $D^{-} D^{\prime}$. See figure 21 for formation symbols. Also figure 20 for cross-section location. 
Summary of Stratigraphic Characteristics

The following is a summary of the stratigraphic character of each of the major formational units in the Black Squirrel Basin. These interpretations are the result of field studies of surface exposures of the units, coupled with interpretation and evaluation of the units on the electric we11 logs.

The Pierre Shale transition zone is characterized by the presence of the basal sandstone, and the upper silty sandstones and shales. The transition zone as a unit shows good lateral continuity throughout the basin (figures 23 and 24), however, there is considerable variation in thickness of both the basal sandstone and the overlying sandstones and shales (figures 27 and 28). The unit thickens northward across the basin (figures 20 and 28).

The Fox Hills Sandstone has fairly consistent thickness and continuity throughout the basin, and appears to be highly variable in lithology. The variations seen on the logs are believed to be due in part to the effects of the many large coalescing concretions.

The massive A and B sandstone units of the Lower Laramie Member are the most easily correlated in the study area because of their consistent thickness and distribution throughout the basin. Both units are composed of medium-grained porous sandstone, and are separated by an interbedded shale unit. The Upper Laramie Member is characterized by lateral variability in thickness of sandstones (figures 23 and 24). Despite the variations in thickness, these sands display fairly good lateral continuity and effective porosity as shown on the logs. These sandstones are interbedded by coals and shales throughout the basin. 
The Dawson is the most variable unit, and is characterized by massivebedded lenticular channel sands and intervening shales. Lateral continuity of the channel sands throughout the basin is very poor as shown by the logs in figures 25 and 26. These sands range from very dense with low effective porosity to very loose with moderate porosity and permeability.

\section{Conclusions}

Important stratigraphic information such as lithology, thickness, lateral continuity, and vertical variation of bedrock units can be gained through interpretation of geophysical well logs, coupled with field studies of the units involved. This information is directly applicable in interpreting regional hydrogeologic conditions in a ground water basin. Conclusions from this report which have resulted from this approach are as follows:

1. The combined Fox Hills-Lower Laramie Member is the major bedrock unit capable of transmitting significant quantities of ground water from the B1ack Squirrel Basin northward into the Kiowa-Bijou Basin. This conclusion is based on the fact that the combined unit has an average thickness in excess of 200 feet, and has stratigraphic continuity throughout the basin. In addition, medium grain size and moderate cementation is observed in the field, coupled with well log data, indicate relatively high permeability.

2. The basal sandstone of the Pierre Shale transition zone may also be transmitting water northward to the vicinity of the South Platte River. The basal sandstone averages over 100 feet thick, is stratigraphically continuous throughout the basin, and shows efidence in field outcrops and well logs of moderate permeability. 
3. The upper part of the transition zone, Upper Member of the Laramie Formation, and the Dawson Formation are considered to be of little importance in the regional transmission of ground water. This is due to the abundance of shale and silt, and the lenticular nature of the sandstones. 
VIII. GEOLOGIC DETAIL - BEDROCK STRATA INVOLVED IN GROUNDWATER

TRANSFER FROM THE HIGH PLAINS BASIN INTO THE

SOUTH PLATTE RIVER BASIN

The purpose of this phase of the investigation is threefold. First, to determine if there are permeable units within the bedrock which underlie this portion of the High Plains Ground Water Basin; second, to study the continuity, i.e., lateral extent, of these units; and third, to determine if hydraulic conditions are present which will allow water transfer from the High Plains Ground Water Basin to the South Platte River.

\section{Location of the Area}

The study area is located in northeast Colorado (see figure 29), and includes parts of Washington, Yuma, Sedgewick, Phillips, and Logan counties. Approximately the northern one-third of the High Plains designated ground water basin is encompassed within the study map.

\section{Topography}

The study area lies within the High Plains Section of the Great Plains Physiographic Province. A rolling, gentle, easterly dipping plain, somewhat modified by intermittent streams and surficial dune sands, characterizes this region's topography. The elevation of the land surface ranges from a high of 4800 feet south of Akron to a 1 ow of 3500 feet near the northeast corner of the study area.

Except for the South Platte River, streams within the study area are intermittent. All of these intermittent streams head within the northern High Plains or along its western boundary. Where indurated 


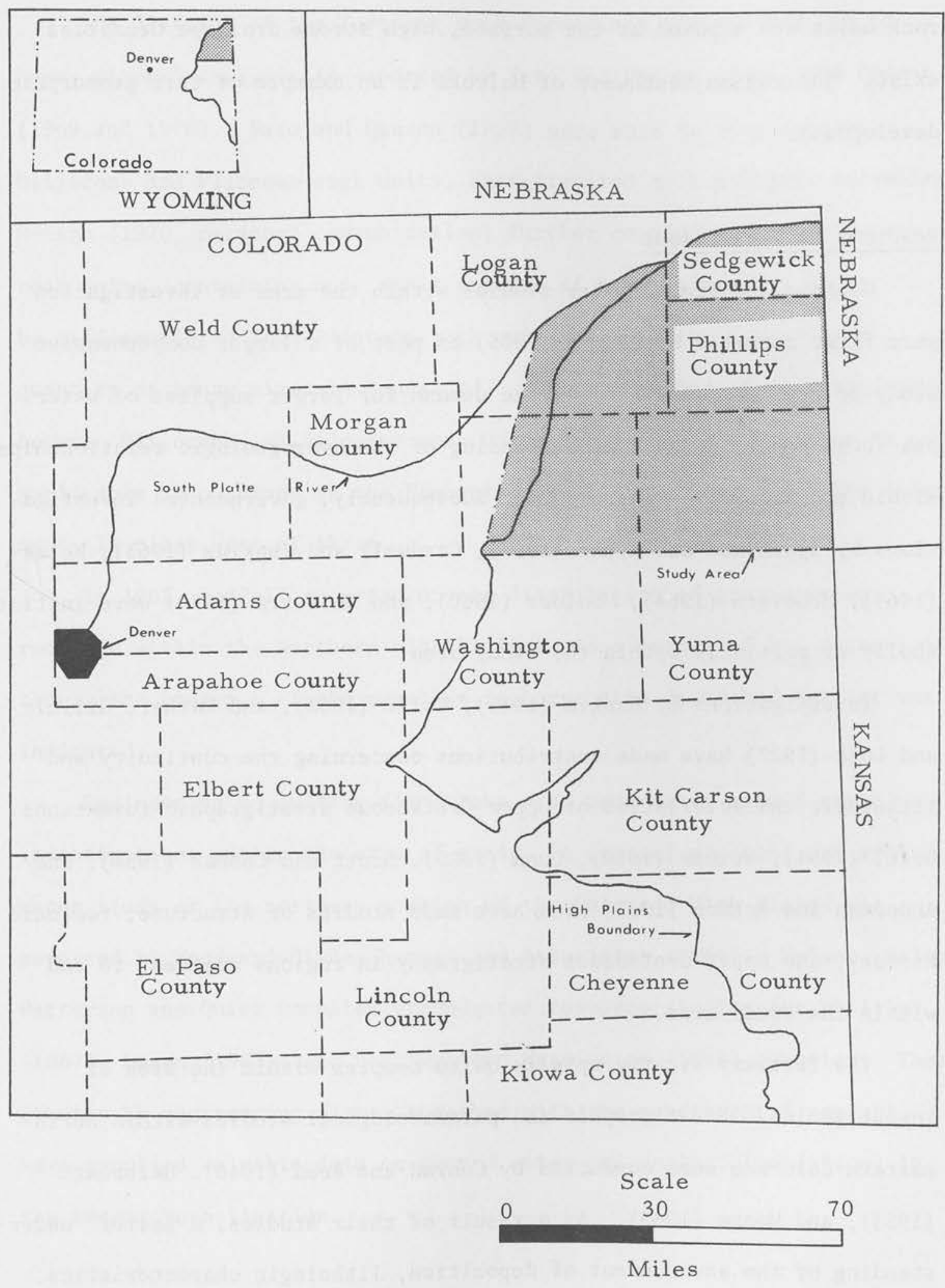

Figure 29. Location Map of Study Area 
rock units are exposed at the surface, high stream drainage densities exist. The region southwest of Holyoke is an example of this geomorphic development.

\section{$\underline{\text { Previous Investigations }}$}

Geology and ground water studies within the area of investigation were first reported by Darton (1905) as part of a larger comprehensive study of the Great Plains. As the demand for larger supplies of water has increased, a greater understanding of the hydrogeologic relationships within the subsurface was needed. Subsequently, governmental investigations by Bjorklund and Brown (1957), Cardwel1 and Jenkins (1963), Weist (1964), McGovern (1964), Moulder (1960), and Holfstra (1970) were initiated wholly or partially within the study area.

Investigations by Rankin (1933), Nolte (1963), and Mather, Gilluly and Lusk (1927) have made contributions concerning the continuity and 1ithologic characteristics of Upper Cretaceous stratigraphic formations. Oriel (1954), Weimer (1959), Dunn (1959), Scott and Cobban (1954), and Anderman and Ackman (1963) also have made studies of structure, tectonic history, and Upper Cretaceous stratigraphy in regions adjacent to and within the study area.

The Tertiary stratigraphy is quite complex within the area of investigation. Stratigraphic and paleontological studies within northeastern Colorado were conducted by Conrad and Reed (1940), Galbreath (1953), and Moore (1963). As a result of their studies, a better understanding of the environment of deposition, lithologic characteristics, and continuity of rock units within the study area was attained. 
The division of the Tertiary rock formations through the use of heavy mineral analysis is reported by Sato and Denson (1967) and Denson (1969 and 1970). Sato and Denson (1967) were able to distinguish Oligocene and Pliocene rock units, characterized by a plutonic assemblage. Denson (1970, personal communication) further concluded that 01igocene rock units, containing only small amounts of heavy minerals, could also be differentiated from Pliocene rock units, due to the disparity in quantity of heavy minerals contained. Denson's method of distinguishing between 0ligocene and Pliocene rock units was found by the writer to be applicable at outcrops in the Fremont Butte district and along the escarpment $1 \frac{1}{2}$ miles west of Akron.

In 1967, Reddel1 reported on the distribution of ground water recharge within the Northern High Plains. As a result of his investigations, the presence of the negative recharge area described earlier was indicated.

Engineering consulting firms have also undertaken ground water investigations within the area of study. A general geologic and ground water study of the northern portion of the Colorado High Plains was reported by Woodward-Clyde-Sherard and Associates (1966). Nelson, Haley, Patterson and Quirk compiled groundwater resource studies for Phillips (1967), Logan (1967), and northwestern Washington (1968) counties. These studies by engineering firms, together with the governmental reports, have supplied valuable data on ground water and geologic conditions to the thesis investigation. 
Methods of Investigation

The study consisted of a stratigraphic investigation of bedrock units which might be significant in ground water flow. The stratigraphic investigation was divided into three parts. The first part was a review of the literature. Field studies conducted by the writer during the summer of 1970 composed the second part. The third part of the investigation consisted of the evaluation of geophysical well logs. Geophysical we11 logs were obtained from petroleum companies, engineering consulting firms, and field measurements.

When the geophysical well logs are evaluated in conjunction with a driller's log, characteristics such as rock type, bed thickness, continuity of rock units, and the position of the water table or piezometric surface can be discerned.

Geologic cross-sections were constructed within the study area in order to determine if geologic and hydraulic conditions are present which will allow ground water transfer through permeable bedrock units within the High Plains Basin to the South Platte River.

Geology and Geologic History

Geology - Rock units that crop out within the study area range in age from Late Cretaceous to Recent. The stratigraphic unit that is the thickest and underlies the entire area is the Pierre Shale of Late Cretaceous age. The Tertiary is represented by the Oligocene White River Group and the Pliocene Ogallala Formation. The White River Group is restricted to the north, central, and western portions of the study area. The Ogallala Formation, however, is more widespread and extends almost to the boundaries of the area of investigation (see figures 30, 31, and 32). 


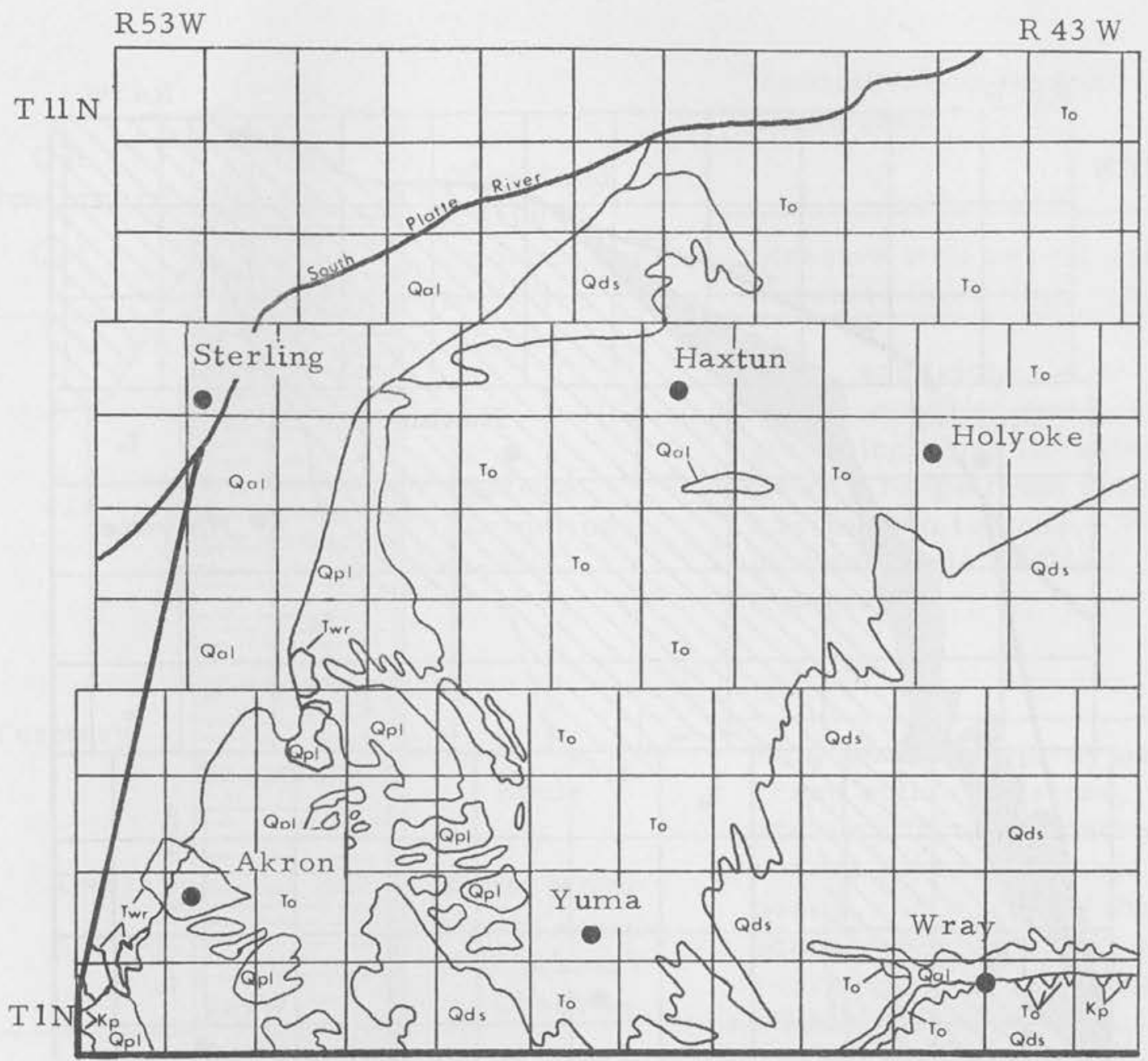

(Adapted from: McGovern (1964), Wiest (1964), and WoodwardClyde-Sherard and Associates, (1966)

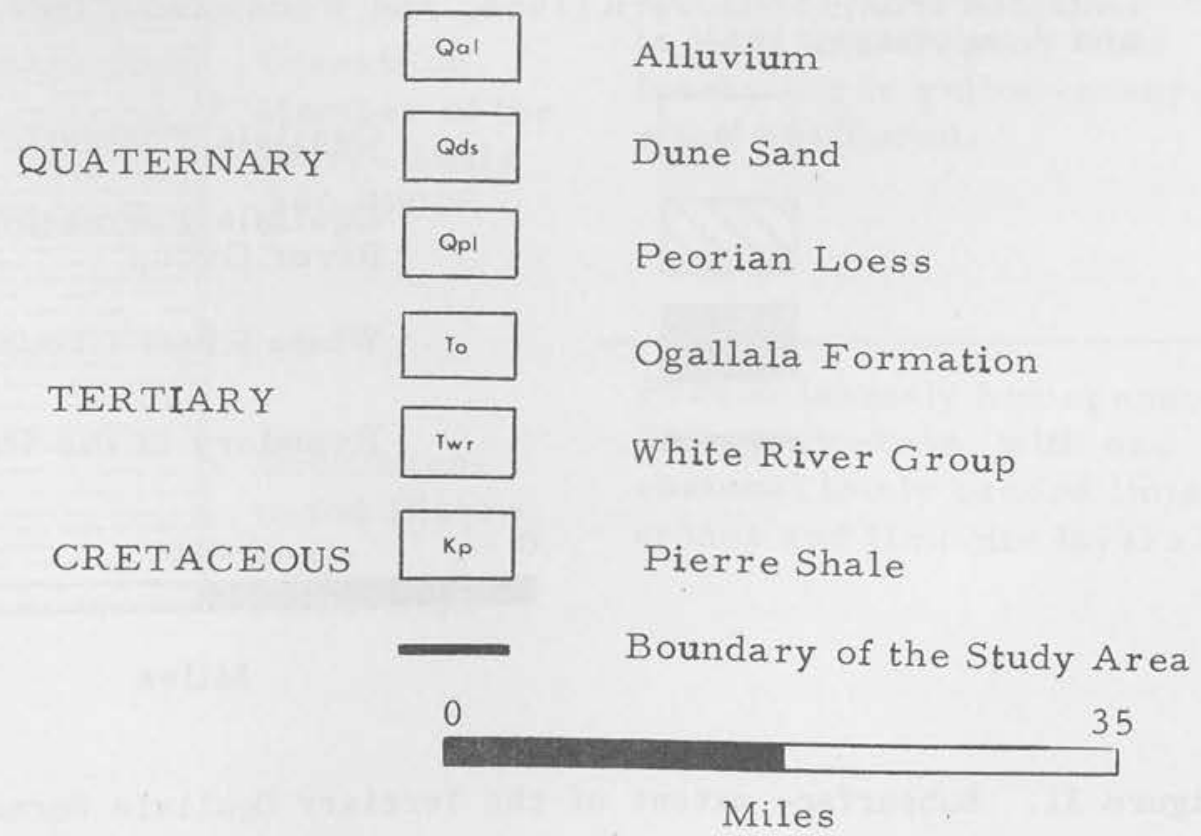

Figure 30. Surface geology map 


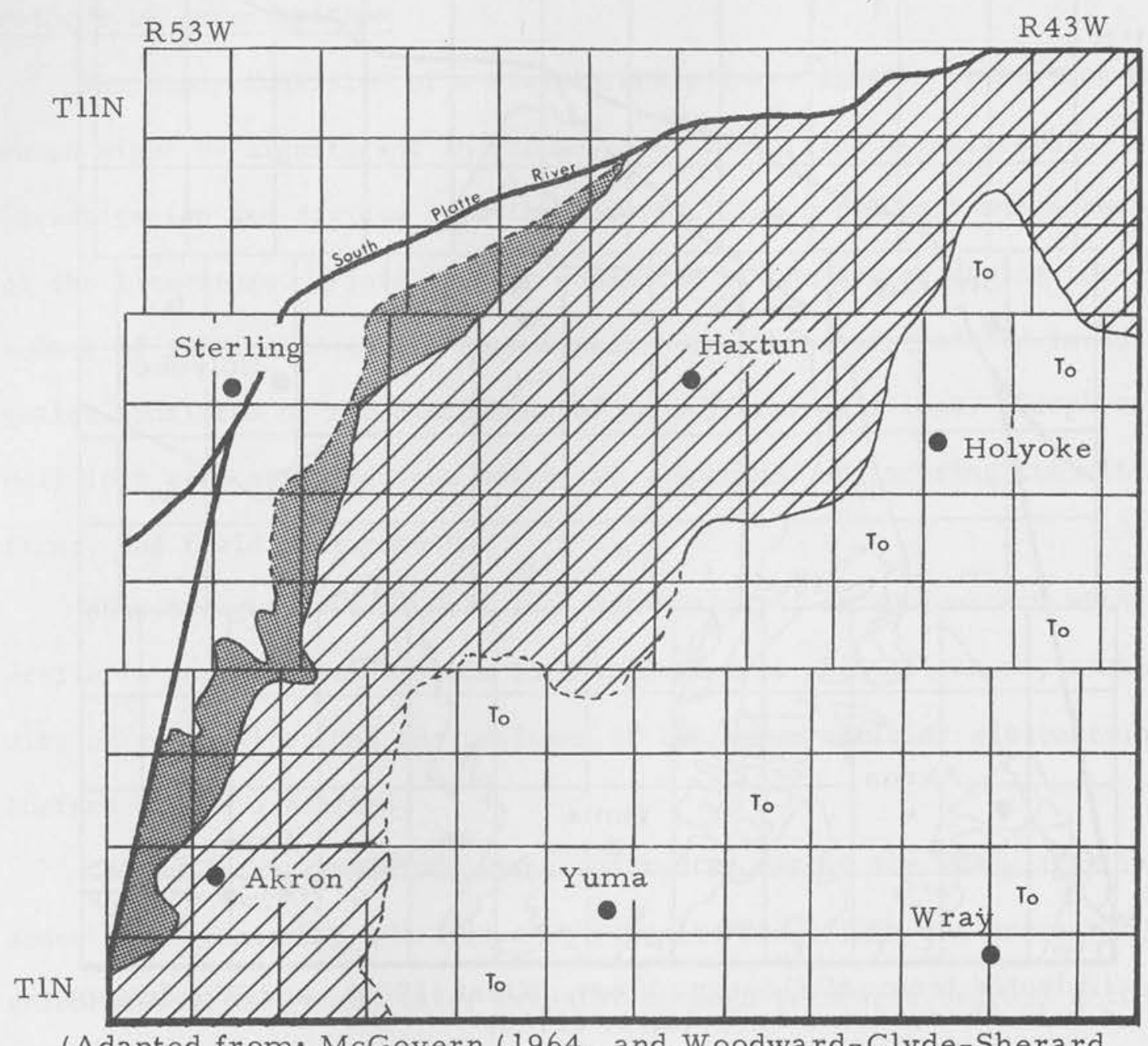

(Adapted from: McGovern (1964, and Woodward-Clyde-Sherard and Associates, 1966)

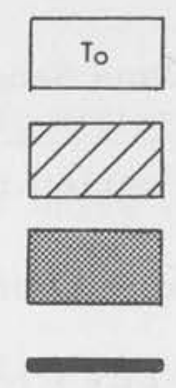

Ogallala Formation

Ogallala Formation and White River Group

White River Group

Boundary of the Study Area

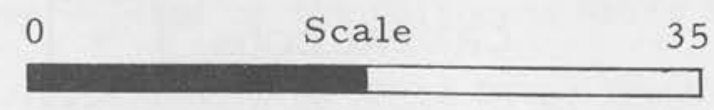

Miles

Figure 31. Subsurface extent of the Tertiary Ogallala Formation and White River Group. 


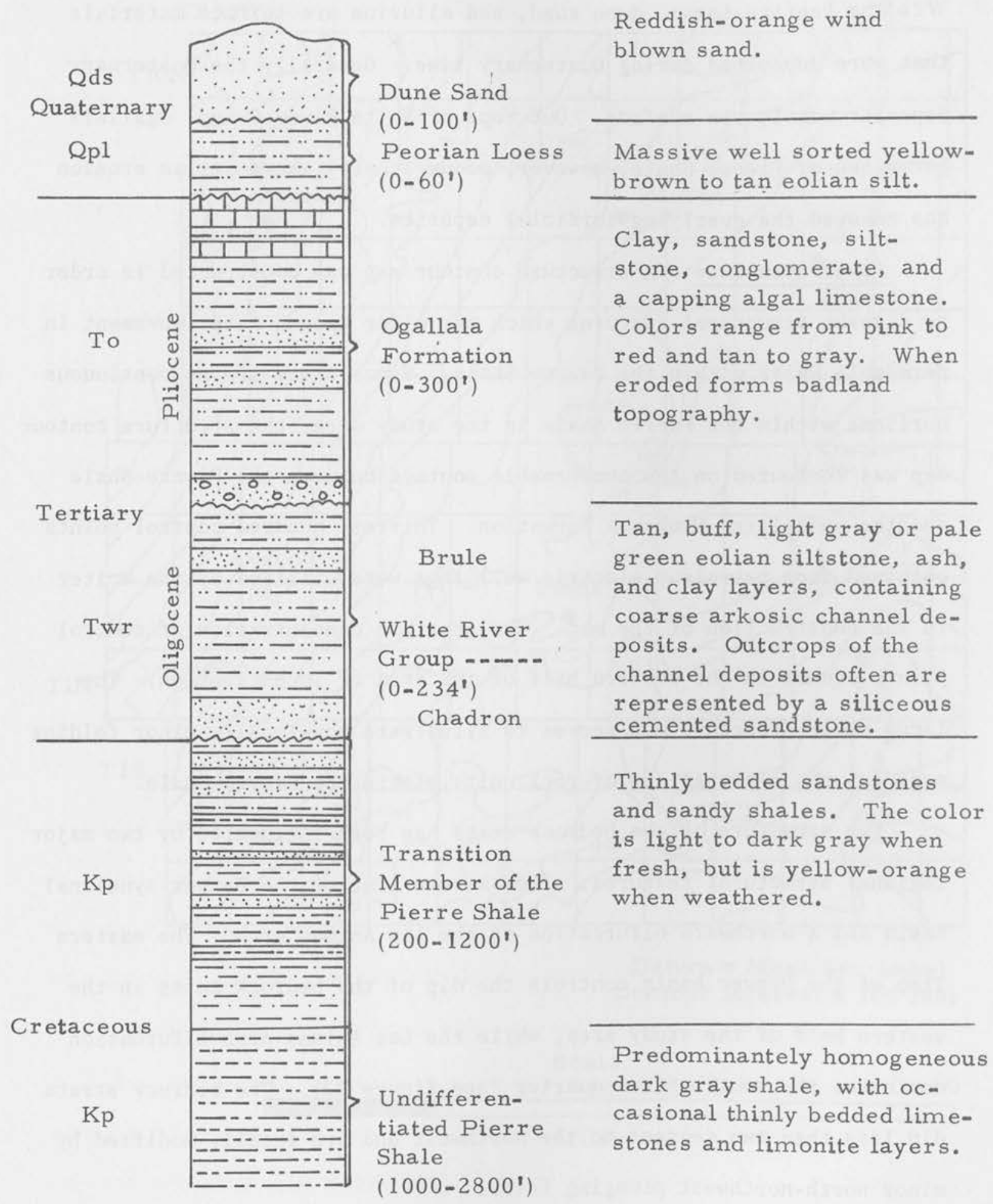

Figure 32. Generalized columnar section of the study area. 
The Peorian Loess, dune sand, and alluvium are surface materials that were deposited during Quaternary time. Generally the Quaternary deposits mantle the surface. Outcrops of White River Group, Ogallala Formation or Pierre Shale, however, occur locally where stream erosion has removed the overlying surficial deposits.

Local Structure - A structure contour map was constructed in order to discern structural features which may alter ground water movement in permeable units within the Pierre Shale. Since there are no continuous horizons within the Pierre Shale in the study area, the structure contour map was contoured on the conformable contact between the Pierre Shale and the underlying Niobrara Formation. Thirteen hundred control points obtained from petroleum electric well logs were utilized by the writer in the construction of the map. The greatest concentration of control points occurs in the western half of the area of investigation. The large scale structure map serves to illustrate how locally minor folding modifies the regional dip of rock units within the Pierre Shale.

The structure of the bedrock units has been influenced by two major regional structural features: The eastern limb of the Denver synclinal basin and a northward bifurcation of the Las Animas arch. The eastern limb of the Denver basin controls the dip of the bedrock units in the western half of the study area, while the Las Animas arch bifurcation dominates the southeastern quarter (see figure 33). The bedrock strata dip less than two degrees to the northwest and are locally modified by minor north-northwest plunging folds.

Geologic History and Geomorphic Implications - Information on the continuity and general hydrogeologic properties of rock units may be obtained through a study of the regional geologic history. In this 


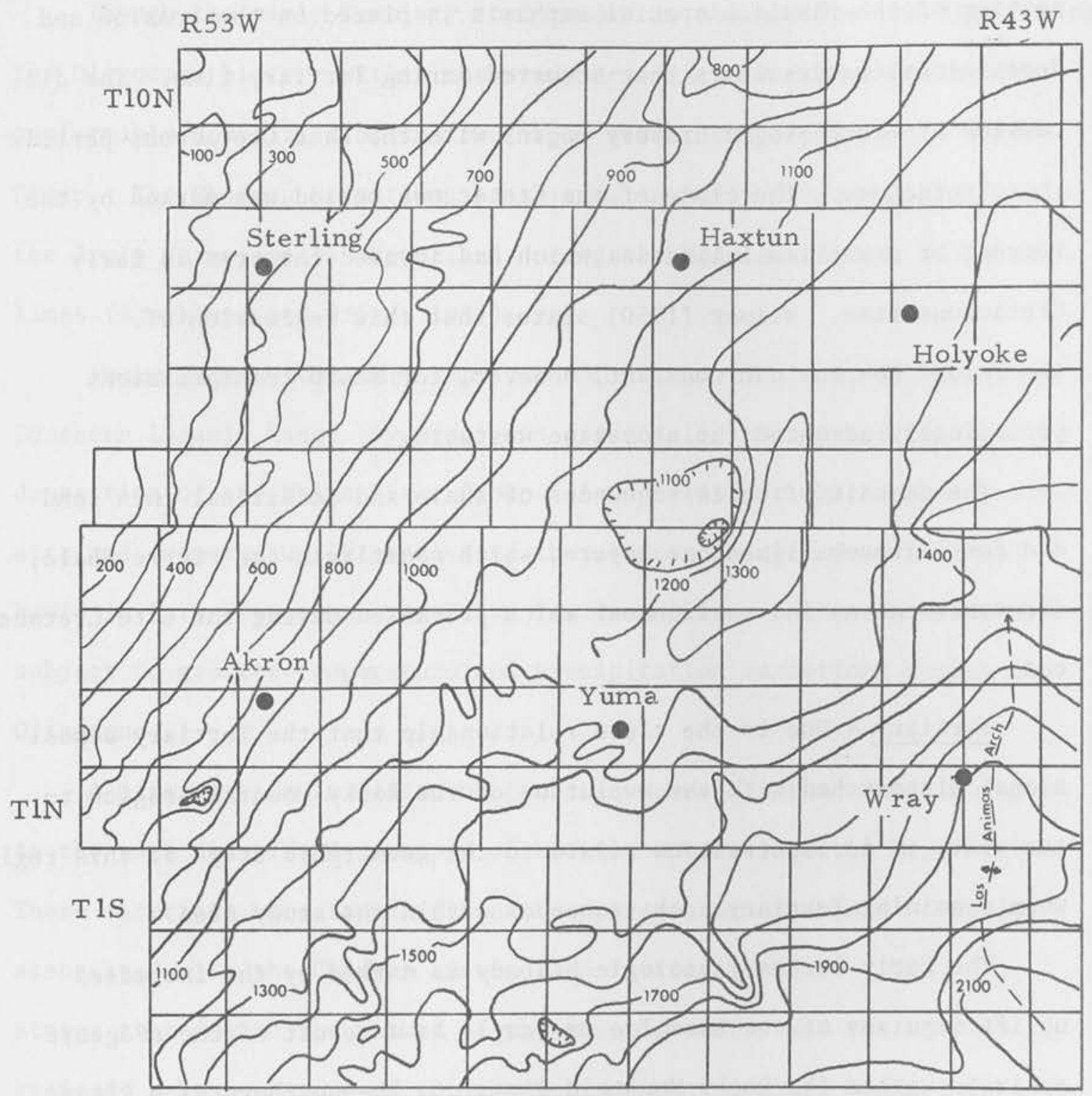

Datum $=$ Mean Sea Level

Contour Interval $=100$ feet

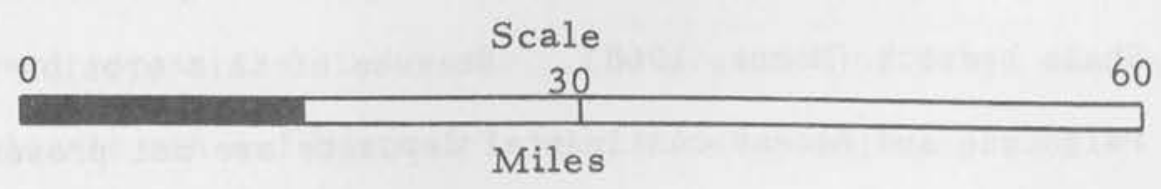

Figure 33. Local structure contour map on the base of the Pierre Shale. 
section of the thesis a special emphasis is placed on the erosion and depositional environments that occurred during Tertiary time. The discussion of the geologic history begins with the Late Cretaceous period. Cretaceous - The close of the Cretaceous period was marked by the retreat of a shallow inland sea which had invaded the area in Early Cretaceous time. Weimer (1959) states that this regression of the inland sea was not constant, however, for sharp transgressions periodically advanced the shoreline westwerd.

The deposit of thick sequences of shale and occasional thin sand and fossiliferous limestone layers, which constitute the Pierre Shale, documents the marine environment which prevailed during the Late Cretaceous.

Tertiary - Due to the close relationship that the Tertiary depositional history had with the evolution of the Rocky Mountain region to the west, it is important to relate to the geomorphic stage of this region when examining Tertiary rock sequences within the study area.

The Early Tertiary geologic history is marked by the increased uplift impulses of the Laramide Orogeny. As a result of the orogenic activity within the Rocky Mountain district, the northern High Plains also experienced a gentle uplift during this time. Erosion was quite widespread with stream channel drainage developed within the Pierre Shale bedrock (Moore, 1960). Because of this erosion phase, Paleocene and Eocene continental deposits are not present within the study area. Sandstones, arkoses, and other rock units that are of this age, however, are found within intermountain basins and areas adjoining the Rocky Mountain region. 
Though the early Tertiary rock record is absent from the High Plains, the 01igocene history within the study area is we11 documented by the conformable deposition of the two major formations of the White River Group. The Chadron Formation is assigned an Early 01igocene age, while the Brule Formation was deposited during the Middle and Late 01igocene times (Bjorklund and Brown, 1957).

Moore (1960) concludes that the major part of the uplift of the Southern Laramie Range (Wyoming) was essentially over prior to the deposition of the White River Group. As a result of the high elevation attained from the uplift activity, the climate changed from warm and humid in Late Cretaceous and Early Tertiary times, to a much drier climate subject to greater temperature and precipitation variations during the 01igocene.

A minor uplift in 0ligocene times, however, in the mountain region to the west did afford a supply of clastic material to the High Plains. These materials were found within the coarse-grained channel deposits associated with the Chadron and Brule Formations. Moore (1963) states that due to the nature of the fossil remains and the coarsegrained, arkosic nature of the channel sediments, these channel deposits are thought to be indicative of a semi-arid climate where intermittent streams, heading from alluvial fans extending from the mountain fronts to the west, flowed across the study area. The presence of large amounts of wind blown volcanic ash and bentonitic clay is also indicative of a dry and eolian environment for the clay and siltstone units of the White River Group. This volcanic material blown into the northern High Plains was subsequently reworked by the alluvial, colluvial, and eolian processes active within the area. 
The Miocene climate was a continuation of the dry situation that occurred during the 01igocene. The Arikaree Formation is the characteristic deposit of this period. The writer's field studies and geophysical logging investigations have failed to locate Miocene deposits within the study area. Denson (1970, personal communication) and Cardwell and Jenkins (1963) also state that the Arikaree is not present in the subsurface within the northern High Plains. This unit, if ever present, was likely stripped away during the erosion that marked the Early Pliocene.

The Miocene Arikaree Formation is, however, found in pockets north of the South Platte River. Moore (1964) suggests that this unit represents the fillings, deposited in topographic lows, by colluvial and/or eolian processes. Moore (1960) concludes that the combined effects of the 0ligocene and Miocene depisition resulted in the development of an essentially featureless depositional surface, extending from the mountain front in the west to the northern High Plains in the east and beyond. The geomorphic stage of this development would be characteristic of the late maturity classification.

In the northern High Plains, the Early and Middle Pliocene were dominated by erosion processes before giving away to the deposition of the Ogallala Formation in Late Pliocene time. Figure 34 illustrates the easterly slope of the erosion surface developed on the bedrock prior to or during the Ogallala Formation deposition.

Moore (1960) states that the climate during the Pliocene became increasingly drier. Sediments deposited within the area indicate that the region was subject to periodic and intense precipitation, which produced flooding of short flow and duration. 


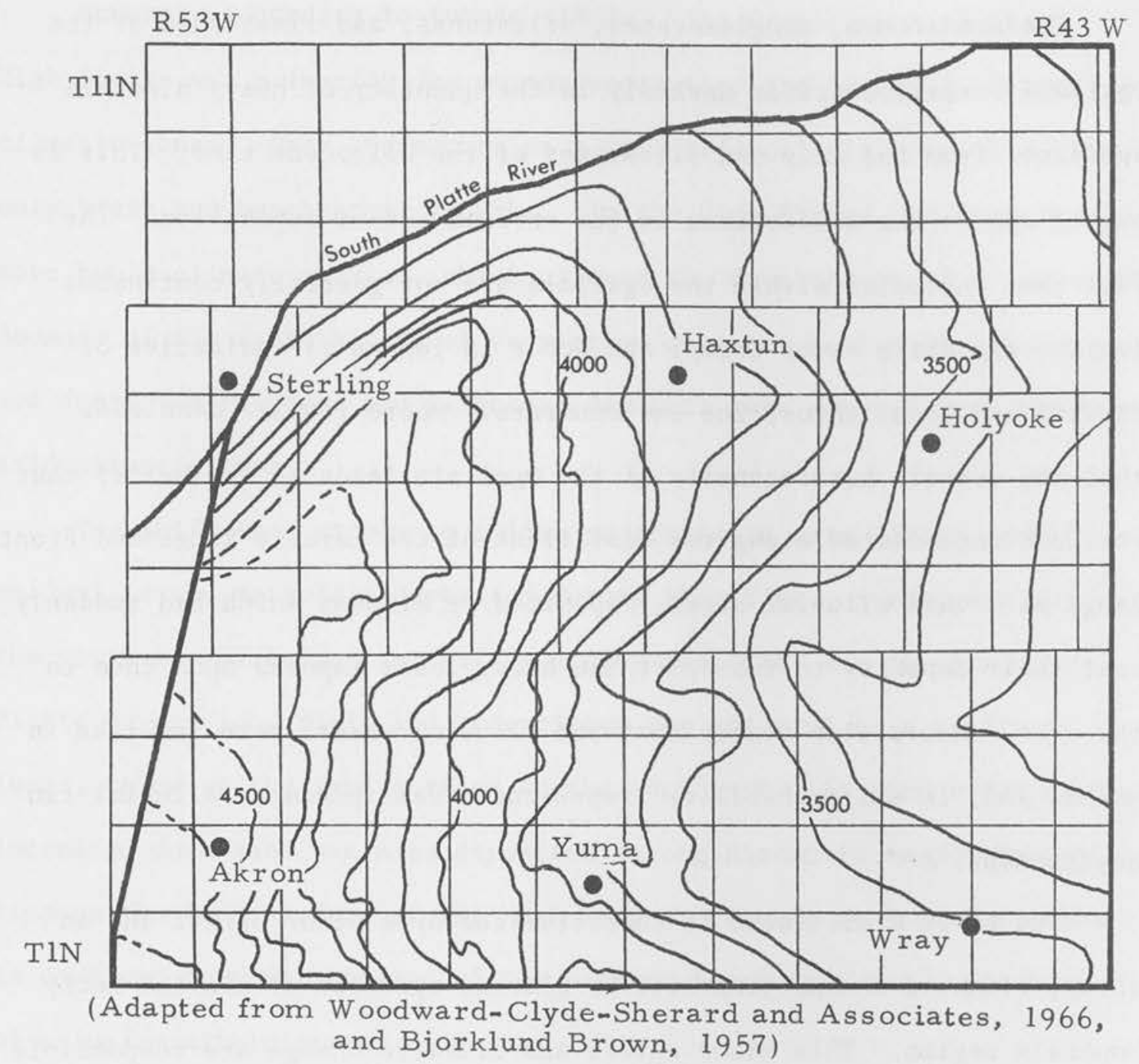
and Bjorklund Brown, 1957)

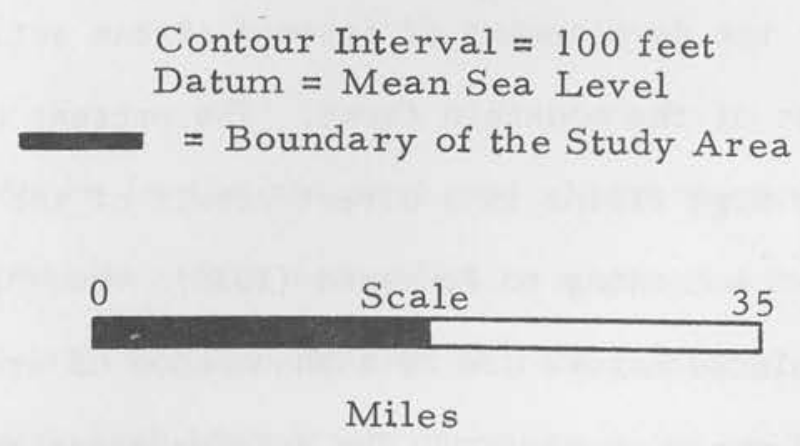

Figure 34. Bedrock contour map on the top of the White River Group or the Pierre Shale 
The sandstones, conglomerates, siltstones, and limestones of the Ogallala Formation differ markedly in the quantity of heavy minerals contained from the clay and siltstones of the 0ligocene time. This is partly due to the differences in the environment of deposition. The fact that the units within the Ogallala are not generally continuous (unlike the White River Group) and occur in lenses is indicative of fluvial and local lacustrine environments. Moore (1963) concludes that the overall heterogeneity of the Ogallala leads to the belief that the unit accumulated along the east flank of the Laramie Range and Front Range as a vast alluvial sheet, deposited by streams which had suddenly lost their capacity to transport the heavy loads imposed upon them to the west. Moore also states that the alluvial sheets were fan-1ike in nature and, in all probability, represent a vast piedmont alluvial fan development .

The Early Pleistocene is characterized by a nimor uplift and an abrupt climatic change generated by glacial episodes within the Rocky Mountain region. This minor uplift and climatic change are responsible for the development of renewed stream activity and erosion to the area east of the mountain front. The present day topographic expression of the High Plains is a direct result of the erosion of this time period.

According to Fenneman (1931) the High P1ains obtained its isolated nature due to a phenomenon of erosion between the mountains and the High Plains. The erosion began near the mountains where streams contained steeper gradients. Land surfaces adjoining the mountain fronts, therefore, were stripped of Pliocene deposits first and this activity continued eastward separating the High Plains from the mountains. 
However, according to Lohman (1953a) the development of the High Plains was primarily due to the vegetation growths in different climatic zones. Near the mountains a semi-arid climate prevailed allowing only brush and bunch grass growths. In the High Plains, however, a more humid climate existed, which allowed the development of a sod cover. Because of the fact that brush vegetation does not resist erosion as sod does, the Pliocene and 01igocene deposits were removed from the semiarid climatic zone.

The shift from stream to eolian processes in Late Pleistocene is evident in the materials deposited during this time. Strong winds from the northwest picked up the silt and clay particles within the South Platte River flood plain and redeposited the material as a mantle of loess, covering the land surface to the southeast. As wind velocites increased dune sand was also deposited during Wisconsin and/or Recent time on the land surface of the High Plains. Recent geologic activity is confined to minor erosion of the present topography and depisition of alluvium within stream valleys.

$\underline{\text { Stratigraphy and Hydrogeology }}$

Pierre Shale - The Pierre Shale is the thickest and oldest formation cropping out within the area of study. This formation is a gray to dark gray fissile shale that contains appreciable amounts of thinly bedded sandstones, shaly sands, limestones and limonitic concretions, as well as an occasional bentonite layer.

The Pierre Shale thickens stratigraphically in a northwesterly direction. A thickness of just under 2,000 feet in the southeast portion and approximately 4,000 feet along the western boundary of the study 
area is indicated by oil field well logs. The Pierre Shale dips very gently, i.e., one degree or less, to the northwest, but this general trend is modified somewhat by minor north-northwest plunging folds.

Based on fossil content and 1ithologic characteristics, Griffitts (1949) separated the Pierre Shale into four members: (from oldest to youngest) the Sharon Springs, Rusty, Hygiene and the Transition Members. The lowest member, the Sharon Springs, is characterized be its lack of fossils. The Rusty Member is distinguished by its red-brown limonitic concretions, while the Hygiene Member is noted for its zones of sandstones. The overlying Transition Member is composed of sandy shales and sandstones that, outside the study area, grade into the Fox Hills Sandstone. Because they contain permeable beds, the Hygiene and Transition Members will be considered in more detail than the relatively impermeable Rusty and Sharon Springs Members.

Sand units of the Hygiene Member have been noted by investigators to extend into northeastern Colorado. As these sandstones extend eastward across the Denver Basin's eastern limb, their shale content increases; eventually they grade into sandy shale. As illustrated in figure 35 , these sandstone units of the Hygiene Member do not extend into the area of study.

The overlying Transition Member is composed of two sandy members. The lower of the two units is more widespread and underlies the entire area of investigation. Dips determined from the correlation of electric well logs indicate gentle dips, ranging from $7 \frac{1}{2}$ minutes to 1 degree 30 minutes in magnitude, and ranging from northwest to northeast in direction. 


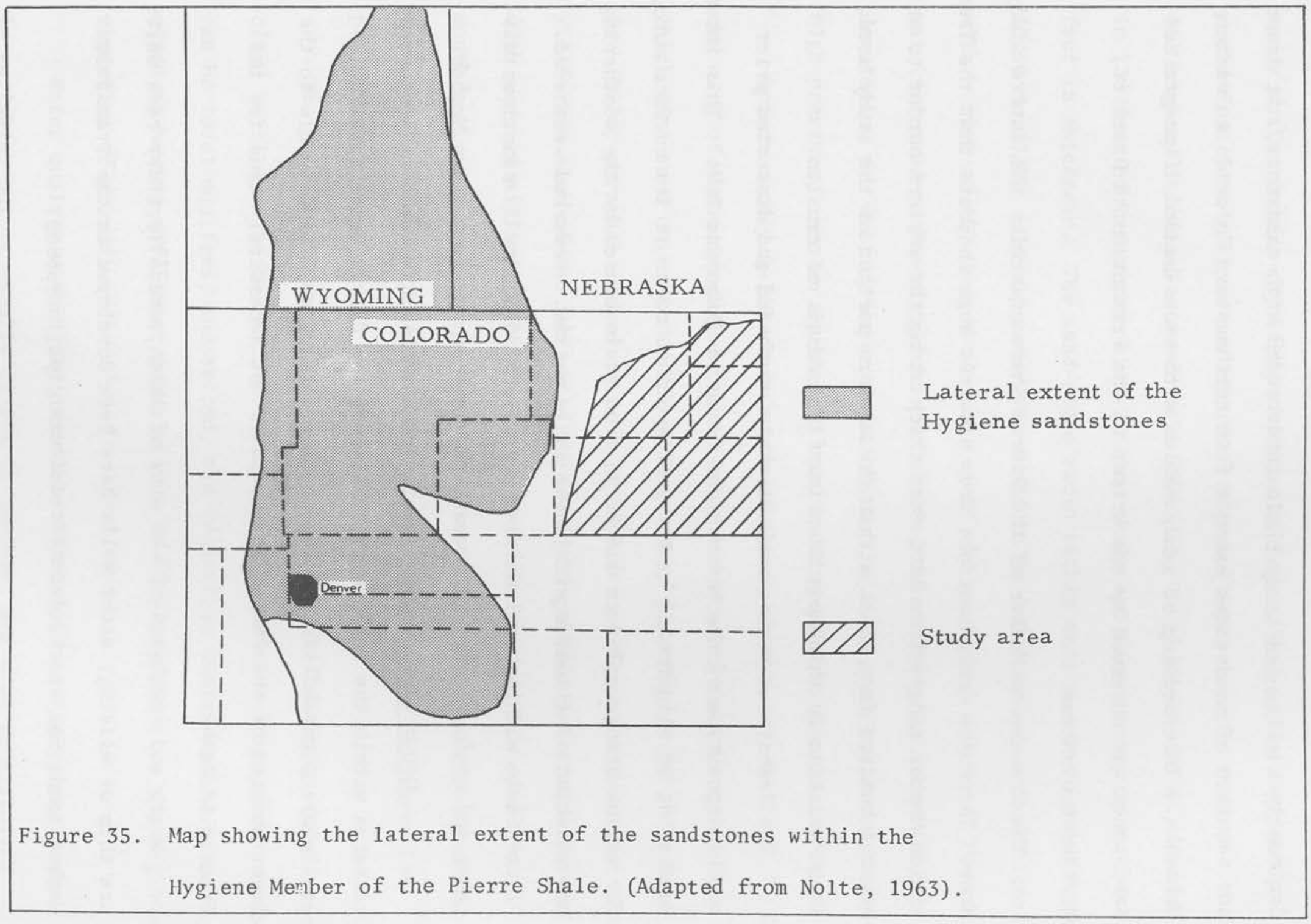


Degraw (1969) indicates that the Transitional Pierre is predominantly a silty and sandy shale interbedded with sandstone. At least one sequence of sandstones extends from northeastern Colorado to western Nebraska. Interbedding of sandy shales with cross-bedded, fine-grained sandstones was observed by the writer in the Fremont Butte District, northwest of Akron.

The Transition Member of the Pierre Shale underlies the entire study area. Thickness determinations from electric logs indicate that the Transition Member ranges from 1100 feet thick along the western border to only several hundred feet thick within the eastern portion of the study area. This variation in thickness is primarily a result of erosion.

The Transition Member was intensely weathered and dissected prior to the deposition of the White River Group in Oligocene Time. This intense weathering is illustrated by the yellow-orange color at its surface outcrops. The yellow-orange color is due to an iron stain caused by the weathering and solution of limonite within the shale matrix. Reworked weathered Pierre Shale within basal White River channel deposits is sometimes mistaken and confused with this weathered zone of the Transition Member. Occurrence of ground water - Previous investigators conducting research within the study area considered the Pierre Shale to have negligible permeability. Although this assumption is applicable to the lower members of the Pierre Shale, it is not necessarily true for the Transition Member.

North and southwest of the city of Akron, where Tertiary rock units are thin or missing, water we1ls have been developed in the Transition Member sands for stock, domestic and municipal purposes. 
Weist (1965) states that wells tapping these sandstone and sandy shales in the adjoining counties of Logan, Morgan and Sedgwick, yield from 5-30 gallons per minute. Degraw (1969) states than an oil company developed a water sel1 (Sec. 15, T. 13 N., R. 55 W., Nebraska) in 120 feet of Transition silts, silty shale and fine sands, up to 1.5 feet in thickness. The sand-shale ratio within this section ranged from $50 / 50$ to $70 / 30$. Ground water was found to be under artesian conditions, with a rise of 450 feet above the top of the producing aquifer. The yield was increased to 36-44 gallons per minute, twice the original yield, by developing the well by water fractionation, i.e., injecting water, under high pressure, into an aquifer to open bedding planes, fractures, etc. Approximately 1-1/2 miles south of Akron, in Sec. 17, T. 2 N., R. 52 W., the city of Akron developed two artesian water we11s in a 15 to 25 foot thick fine sand unit of the Transition Member (see figure 36). Al Ward, Sr. (1970, personal communication), a resident of Akron, states that the yielf from each of the two wells averaged 100 gallons per minute initially, with over 14 million gallons being pumped from the aquifer over a two month period. Larger pumps were later installed, but increased pumping rates pulled the fine sands and silts into the well and destroyed the production.

The preceding examples of water yield from the Transition Member were cited to illustrate two points: first, the sands of the Transition Member can be local aquifers; and second, the Transition Member should be recognized as having sufficient permeability to be significant in the regional migration of ground water.

Water quality within the permeable layers of the Transition Member is variable, but it usually is low in hardness and high in dissolved 


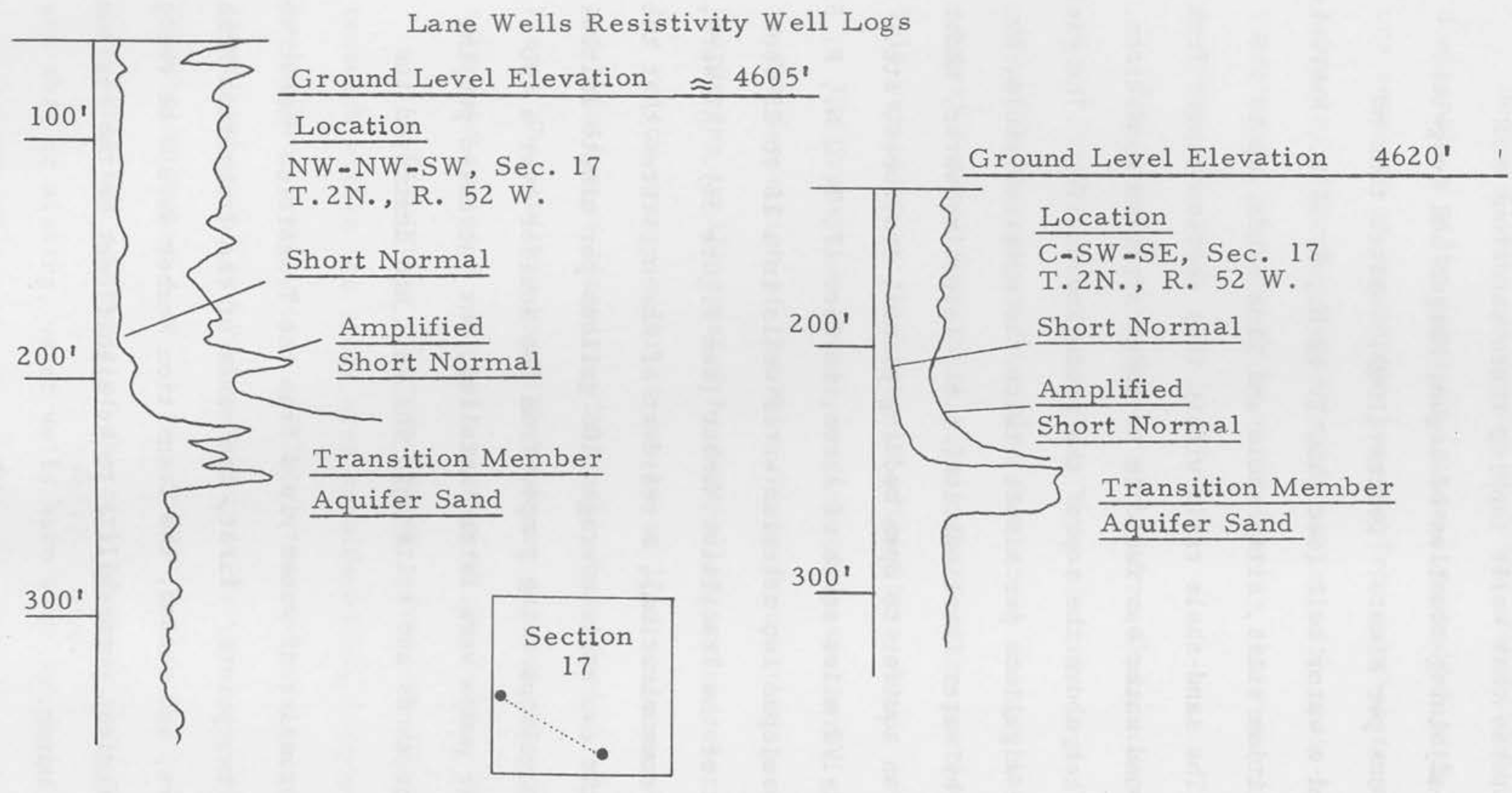

Figure 36. Local continuity of an aquifer sand within the Transition Member. 
solids. Bjorklund and Brown (1957) state that the principal

constituents in the ground water are sodium and bicarbonate. Chloride is also found in appreciable amounts with only minor quantities of sulfate being present.

$$
\text { Ground water flow - Ground water in the Transition Member was }
$$

found usually to exist under artesian conditions. Recharge to this member occurs wherever the hydraulic head of the overlying saturated materials exceeds the piezometric head found within the Transition Member. The greatest amount of ground water recharge is though to occur where permeable Tertiary gravels are in direct contact with the sands of the Transition Member (see figure 37) having a lower piezometric level. This most likely occurs in bedrock paleo-stream channels eroded into the Transition Member.

Continuity - Interbedded layers of sand and sandy shales within the Transition Member underlie the entire area of study (see figure 38). The thickness of the member varies due to stratigraphic thinning and erosion. The Transition Member thins generally in a southeasterly direction.

If the water quality of the ground water within this member can be assumed to be relatively constant, then the increasing resistivity values on resistivity well logs, as illustrated in figure 37 , indicate a higher sand content in the vertical direction. Individual sand beds attain thicknesses up to 25 feet in the subsurface, but are lenticular in nature. These sand units may be continuous for distances up to 5 miles as indicated by stratigraphic correlations using geophysical well logs . 
Schlumberger Electrical Log

Location C SW SW Sec. 25, T, 5 N, , R. 45 W.

Elev. $=3814^{\prime}$

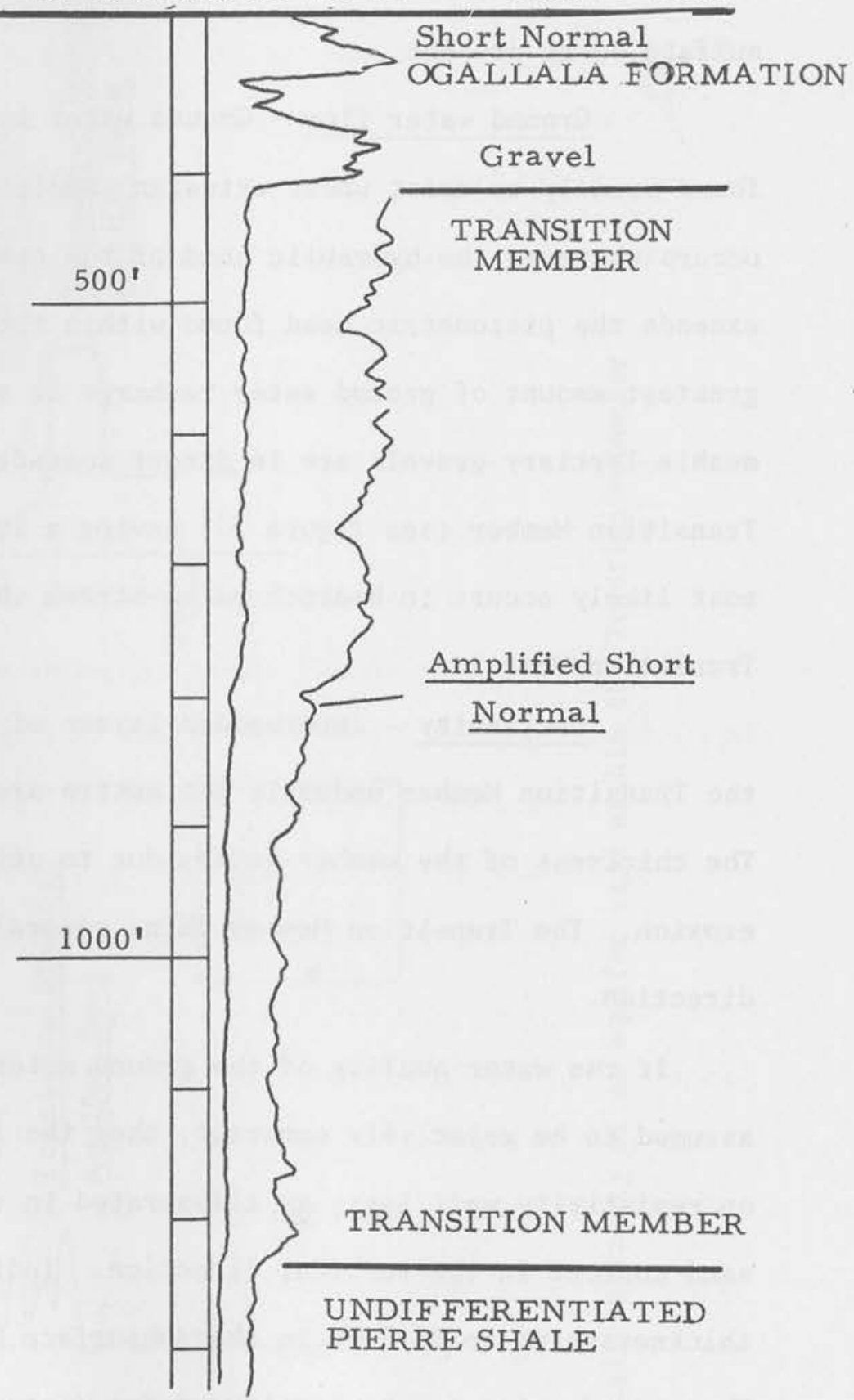

Figure 37. Electric log illustrating an unconformable contact between a gravel unit within the Ogallala Formation and the Transition Member. 


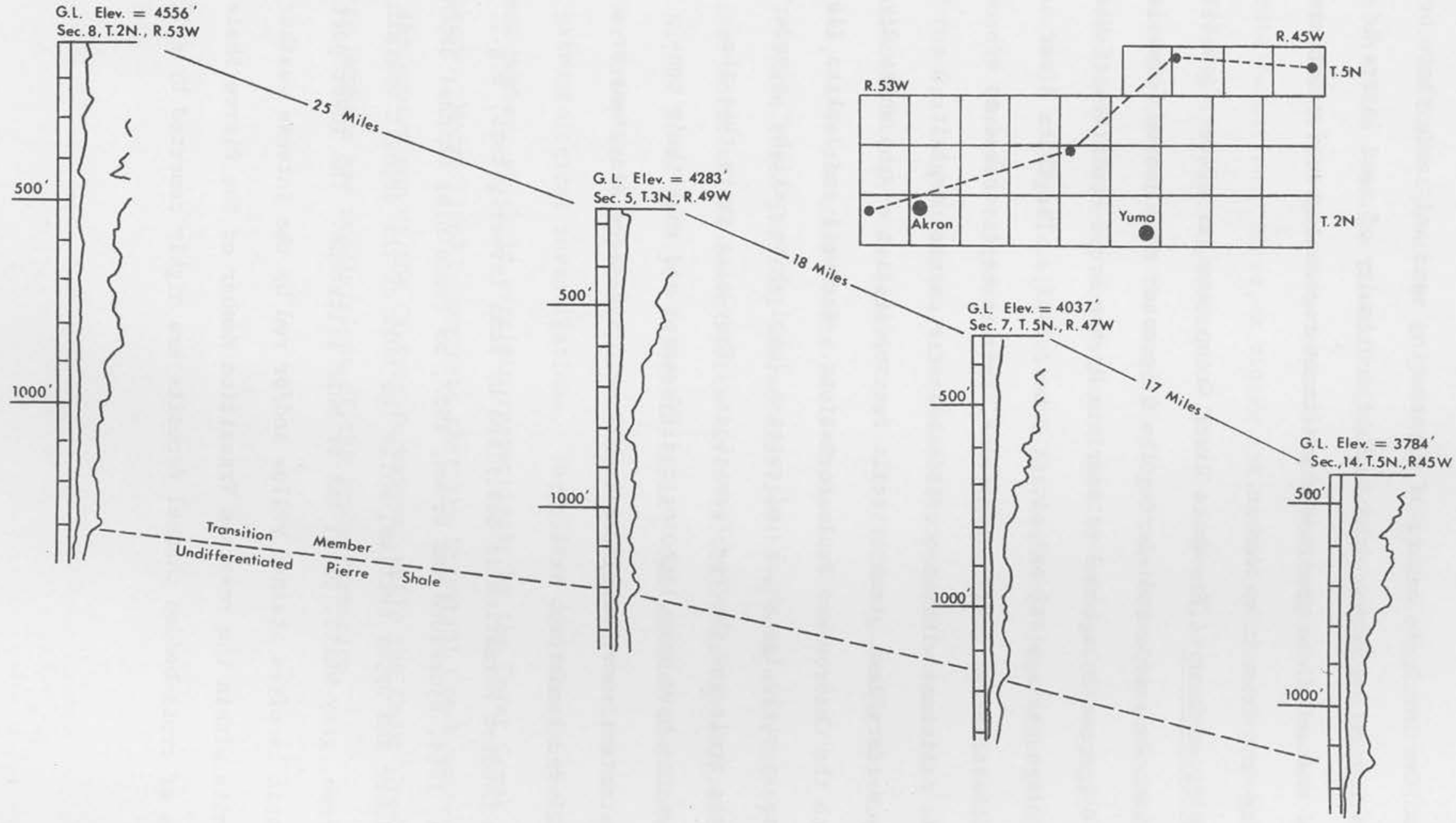

Figure 38. Subsurface electric log correlation map, showing the continuity of the Transition Member across the study area. 
Due to the intricate nature of alternating sand and sandy shale beds within the Transition Member, the lack of continuity of sand layers is not thought by the writer to preclude significant regional ground water movement through the Transition Member.

White River Group - The White River Group consists of two formations, both of which were deposited during the 0ligocene; the Chadron Formation is Early 0ligocene in age and is overlain by the Brule Formation of Middle and Late Oligocene age (Bjorklund and Brown, 1957). The White River Group is characteristically homogeneous, and can be described as a bentonitic siltstone with an occasional coarse channel deposit.

Many writers have given criteria for subdivision of the White River Group into the Chadron and Brule Formations. Cardwe11 and Jenkins (1963) present an electric log which indicates a "hard white caliche" boundary between the Brule and Chadron Formations. They a1so state that the two formations have many lithologic differences and that their conformable contact sometimes is marked by an olive-green claystone or a hard brick-red sandstone.

The Chadron Formation is described by some investigators, e.g., McGovern, 1964, Bjorklund and Brown, 1957, as containing channel deposits in its lower and upper section, while the bulk of the deposit contains olive-green, gray-white, pink, tan or buff siltstone. The lower portion of the unit is often stained yellow and/or red by the intense weathering of limonite within the reworked Transition Member of the Pierre Shale. Outcrops of cross-bedded channel deposits are highly cemented by silica. 
The Brule Formation is generally described as a bentonitic siltstone which often contains channel deposits within its lower section. Several characteristics have been reported that are supposedly common to the Brule Formation. First, a blocky and conchoidal fracture is exhibited often on its exposed surfaces. This is especially intense and pronounced near the contact with the overlying Ogallala Formation. Second, the presence of a nodular concretionary bed is found at the contact between the Brule and Ogallala Formation. Third, the Brule often exhibits a loosely cemented conglomerate of White River Group cobbles at the base of the Ogallala Formation. Denson (1970, personal communication) notes that even though this deposit most likely occured during the Miocene times, it is assigned to the Brule Formation.

These three physical characteristics have been observed by the writer north of the South Platte River in the Peetz Table district (T. 11 N., R. 51-R. 52 W.). Galbreath (1953) has divided the White River Group in this locality into three distinct formations as a result of paleontological investigations. The oldest division is the Horsetail Creek Member, which is overlain respectively by the Cedar Creek and Vista Members. Moore (1963) suggests that the Horsetail Creek member is the equivalent of the Chadron Formation, while the Cedar Creek and Vista Members are subdivisions of the Brule Formation. 
Assigning White River Group deposits solely to either Brule or Chadron Formations within the area of study is quite common in the literature, as well as among local drillers. Conrad and Scherer (1940) assign the White River deposits to the Brule Formation, while McGovern (1964) in Washington County and Weist (1964) in Yuma County attribute these deposits to the Chadron Formation. Fossil evidence in the Freemont Butte district was provided by Lewis (1957, written communication to H. E. McGovern), who found fossils within the White River sediments fifty feet from the top of the formation that were of Middle to Late Chadron in age.

Within the study area, any delineation of formations within the White River Group due to color differences, "marker beds", and/or physical characteristics should be viewed with skepticism. Paleontological criteria for separating the formations seem to be the most reliable. The following conclusions have been developed by the writer in regard to alleged lithologic and physical differences between the White River Formations within the study area:

1) Due to the similarities in the rock types, the Brule Formation represents a continuation of sedimentation processes carried on during the Chadron Formation deposition.

2) Both the Brule and Chadron Formations contain arkosic crossbedded channel deposits and bentonitic siltstones (Moore, 1963).

3) The siltstones of the Brule and Chadron Formations are, for practical purposes, identical to mineralogical composition (Denson, 1970, personal communication).

4) Delineation of the units by color tones is misleading, for this represents weathering and solution of iron containing minerals in the ground water system (Denson, 1970, personal communication).

5) Physical characteristics, such as the blocky fracture, of the Brule are also quite common within the Chadron Formation. 
6) Since the environment of deposition of the units within the White River Group was variable, e.g., intermittent fluvial, eolian, and alluvial fan, reliance on marker horizons such as ash beds, sandstones or caliche zones to delineate formation boundaries is quite hazardous.

7) Due to their common lithologic and physical features, the Brule and Chadron Formations probably have similar hydrogeologic characteristics.

Due to the nature of the thesis investigation and the overall homogeneity of the Oligocene Chadron and Brule Formations, the White River Formations will not be differentiated within the area of study. The deposits of the White River Formations, henceforth, will be referred to collectively as the White River Group.

The White River Group crops out along a topographic escarpment that marks the western boundary of the High Plains basin. Within the area of investigation, the White River Group can be described as a tan to buff, light gray and/or pale green siltstone which contains moderate proportions of coarse channel deposits.

The White River Group was deposited by eolian and intermittent fluvial processes that essentially leveled the gentle pre-0ligocene topography that was eroded into the Transition Member. Dips are therefore very slight, generally less than two degrees in a northerly direction. Denson (1969) states that these low dips probably represent original surfaces of deposition. The greatest thickness of White River deposits, 234 feet, was reported by McGovern (1964) in Section 16, Township 2 North, Range 52 West of the 6th P.M.

The eolian environment of deposition for the siltstone member is illustrated by its individual and reworked ash layers. The siltstone sometimes exhibits a calcareous cement in its upper zone. Where the overlying rock units are absent, the erosion of the siltstone member produces bizarre shapes due to variations in silt content and cementation. 
The siltstone usually contains prominent joint or fracture sets. In the Fremont Butte district (northwest of Akron) these joint and fracture patterns trend N. 25-35 E. and N. 55-56 W. The siltstones also characteristically exhibit an intense blocky fracture pattern in outcrops near the contact with the overlying Ogallala Formation.

The channel deposits within the White River Group are most abundant near the base of the section. Outcrops of these deposits usually are massive, highly indurated cross-bedded sandstones, which attain thicknesses up to eight feet. Outcrops of these sandstones can be observed one mile west of Akron along U. S. Highway 34 and west of Sterling on U. S. Highway 14. Due to the channel sandstone's resistiveness to erosion, outcrops occupy local topographic highs.

It may be noted that these highly indurated channel sandstones were not observed in the geophysical well logs collected by the writer. Local well drillers also report that they do not encounter anything recognizable as a massive and dense sandstone body within the subsurface.

McGovern (1964) states that loose sand is found at the base of the cemented sandstones that form a ridge in Section 15, Township 3 North, Range 53 West of the 6th P.M. The fact that thest highly indurated sandstones sometimes contain loose sand at their base and the channel deposits are poorly indurated within the subsurface may be indicative of a near surface cementation phenomenon.

Occurrence of ground water - The White River Group is composed primarily of a relatively impervious siltstone which yields only small quantities of water. The White River Group, however, does contain two zones where ground water occurs in appreciable amounts. One of the zones occurs at the top of the White River Group and is referred to in 
the literature, e.g., McLaughlin (1948), Lowry (1966), etc., as the "porous zone". The only other zone of significant ground water occurrence is within the coarse channel deposits which are usually located near the base of the White River Group.

The "porous zone" is essentially a highly fractured siltstone which is frequently overlain by a layer of White River Group cobbles. McLaughlin (1948) states that locally the "fractured" or "porous zone" will

yield large quantities of water to wells. In eastern Wyoming and western Nebraska, wells penetrating this zone are known to yield as much as 2,000 gallons per minute. Wells withdraw a large constant supply of water from this zone where saturated river alluvium or sands and gravels within the Ogallala Formation, overlie the "porous zone."

Vertical fractures within the siltstone were examined at the surface in the Freemont Butte District and were found to be tight. Lowry (1966) concurs that the intense degree of fracturing exhibited on surface outcrops is not representative of conditions with depth. Fractures, if continuous with depth, would be expected to be nearly or completely closed. Hence, these fractures are probably not important in transmitting ground water downward to other underlying bedrock units.

The "porous zone" is dependent on overlying saturated deposits for its ground water supply. Where the overlying deposits are thin and/or partially saturated the "porous zone" has a low specific yield. McLaughlin (1948) in describing the "porous zone" in Julesburg, Colorado area, states that the zone is restricted to a position underlying the alluvium, and perhaps should be considered as part of the alluvium. Therefore, due to its intimate hydraulic connection with the overlying materials and its limited vertical extent, the "porous zone" should be considered to be a part of the overlying unconfined ground water flow system. 
The second zone of ground water occurrence is within the coarse channel deposits. The channel deposits consist of variably cemented sands and gravels which range in thickness from 0 to 100 feet. Ground water occurring in these deposits is often found under artesian conditions.

The channel sandstones are not extensive laterally. They are most likely localized in principal valleys and tributaries which were developed on the Transition Member prior to the deposition of the White River Group. The delineation of these paleo-stream valleys, however, is not possible with the subsurface information availabe.

The channel deposits can yield moderate amounts of water. Nelson, Haley, Patterson and Quirk (1967) 1ist three municipal wells at Akron developed within the White River channel deposits as yielding 350 , 300 , and 250 gallons per minute.

Water can recharge these deposits three ways: be seepage through the overlying siltstones; by direct recharge from permeable units within the Ogallala Formation where the overlying siltstones have been removed; and by direct recharge from the sand layers within the Transition Member in bedrock valleys.

The quality of ground water within the channel depostis usually is much better than that occurring with the "porous zone". McGovern (1964, p. 36) states taht the electrical conductivity of the water in the White River Group ranges from about 400 micromhos in the sandstone to a maximum to about 2,000 micromhos in the fractured siltstone.

Ground water flow - Ground water appears to flow in two directions within the White River Group. The lower channel deposits, as well as the overlying clay and siltstones, dip gently in a northerly direction. As illustrated in cross-sections in figures 45 through 51 , the White River Group intersects the South Platte River, due to the regional northerly dip. 
The hydraulic connection between the channel deposits and the South Platte River is essentially the same as described in the artesian Transition Member ground water system. Where permeability conditions are favorable and a higher piezometric head exists, ground water within the channel deposits flows northward and discharges into the South Platte River. Thus, ground water is diverted from the High Plains Ground Water Basin to the South Platte River.

Nelson, Haley, Patterson, and Quirk (1967) measured the piezometric surface levels within the White River channel deposits west and south of Akron. As can be determined from the map (see figure 39), ground water flows in a north-northwest direction, except directly south of Akron where it flows to the southeast. This southeast flow direction can, however, be explained by the presence of two municipal wells south of the city which pump ground water from these channel deposits.

The second ground water flow system within the White River Group occurs in the "porous zone". As previously mentioned, ground water occurring in this zone is usually unconfined and is recharged by the overlying Tertiary deposits. Due to its restriction to the upper section of the White River Group and hydraulic connection with the overlying saturated deposits, ground water within the "porous zone" flows in the same east-northeast direction as ground water in the Ogallala Formation. Continuity - The deposits of the White River Group are chiefly composed of siltstone. The siltstones contain appreciable amounts of clay and, therefore, give low values on the resistivity well $10 \mathrm{~g}$ and moderately high readings on the gamma well $\log$. Due to the overall homogeniety of the siltstones, the White River Group can be correlated throughout its subsurface extent (see figure 40 ). 


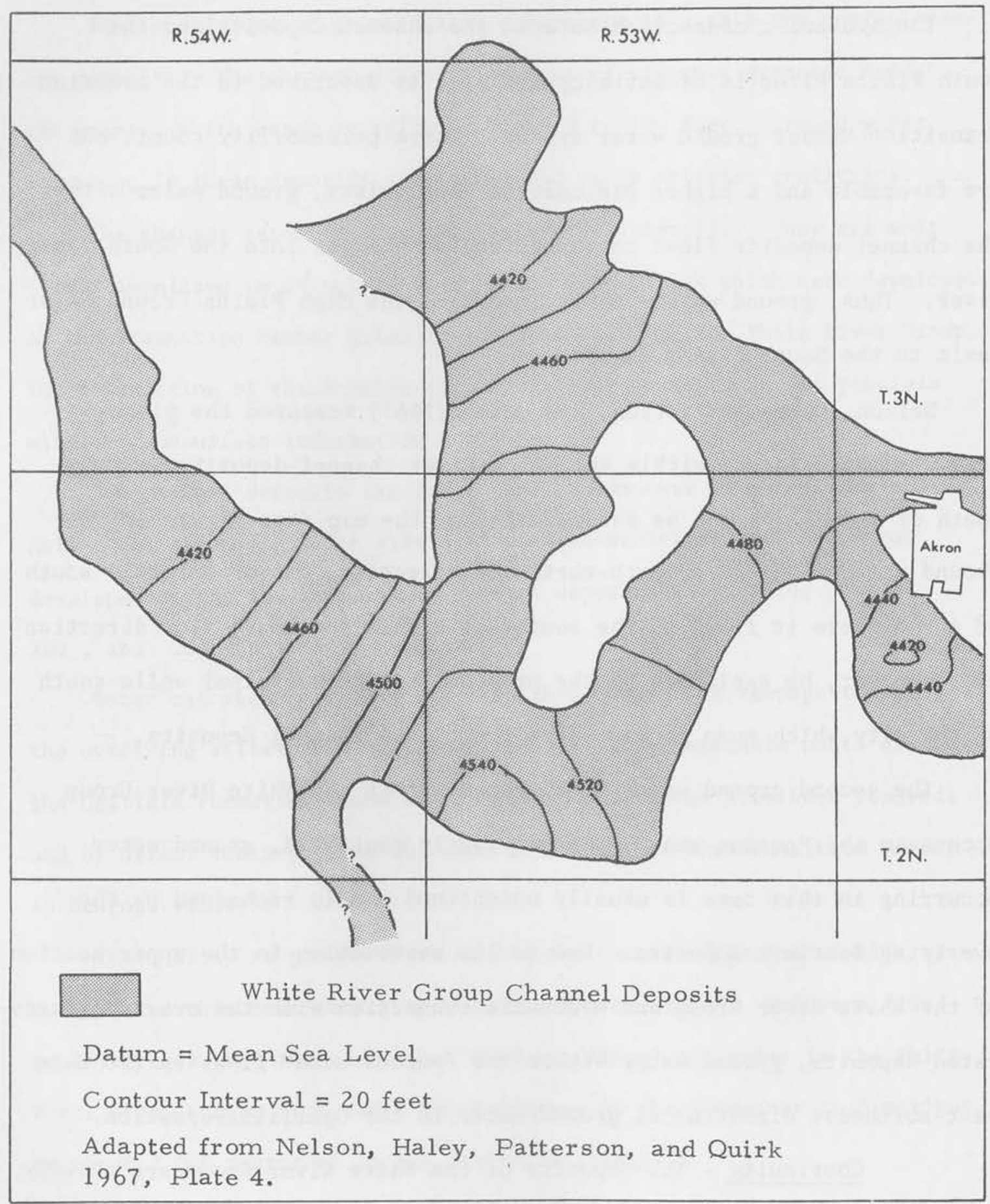

Figure 39. Piezometric surface map for the White River Group channel deposits, south and west of Akron. 


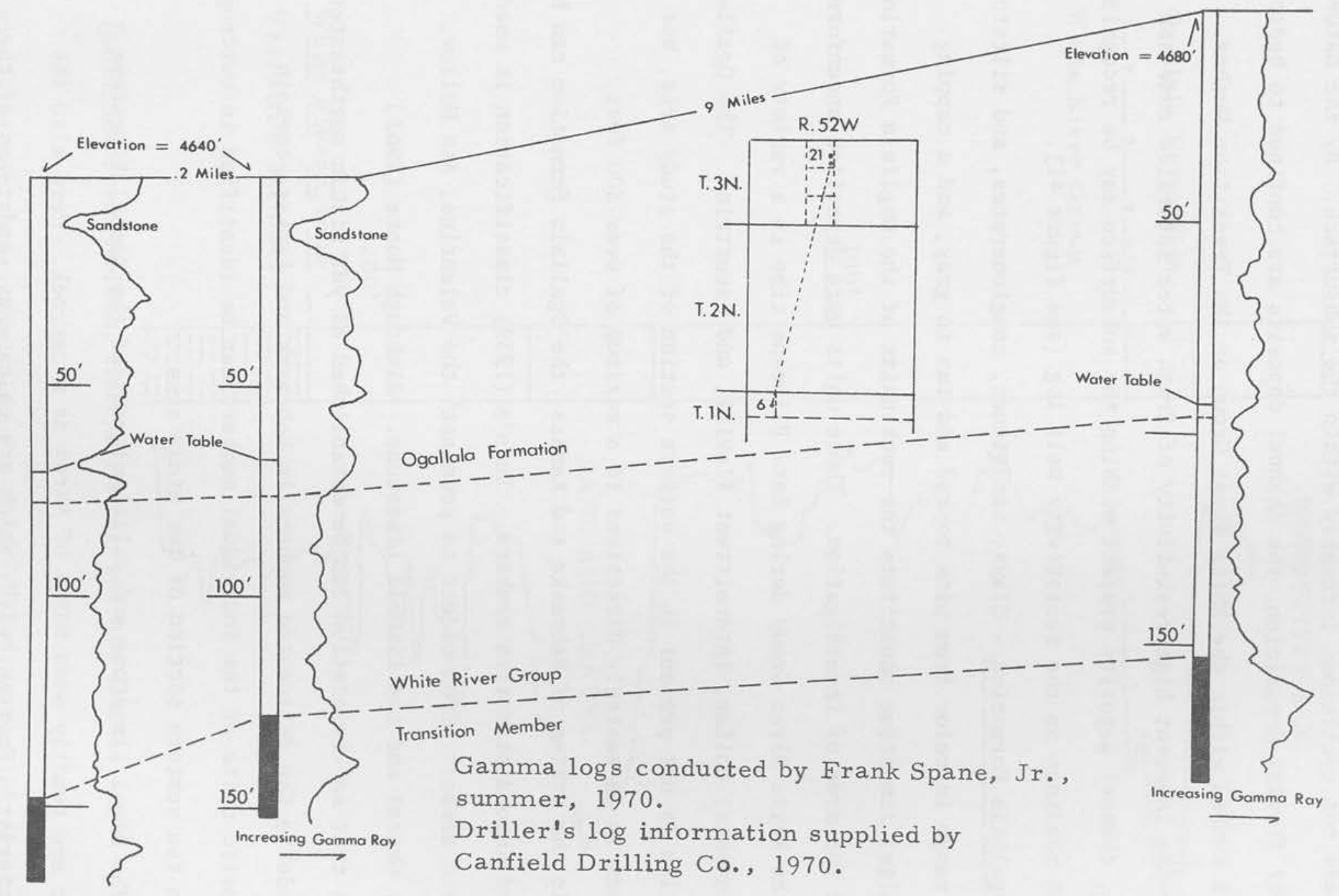

Figure 40. Subsurface gamma $10 \mathrm{~g}$ correlation map, showing the continuity of the White River Group. 
The permeable channel deposits near the base of the White River Group are not continuous laterally within the subsurface. By the nature of their fluvial deposition, the channel deposits are confined to bedrock valleys eroded within the White River Group or the Transition Member. Due to the inherent high resistivity of fresh water saturated zone and gravel, channel deposits present withing the subsurface may be recognized by high readings on the resistivity well $\log$ (see figure 41 ).

Ogallala Formation - Clays, sandstones, conglomerates, and siltstones which range in color from pink to red and tan to gray, and a capping gray algal limestone constitute the rock units of the Oagllala Formation within the area of investigation. These units were deposited unconformably over the White River Group during Late Pliocene time in a variety of environments; eolian, intermittent fluvial, and lacustrine. The Ogallala Formation is not present in the western section of the study area, but thickens in an easterly directions to a maximum of over 300 feet.

In the states of Nebraska and Kansas, the Ogallala Formation can be divided into distinctive members. Lugn's (1939) classification is used in these areas: (from oldest to youngest) the Valentine, Ash Hollow, Sydney Gravel and the Kimba11 Limestone. Although Moore (1963) states that no correlation can be established as yet within northeastern Colorado to the delineated members in Nebraska and Kansas, certain diagnostic units of the individual members can be identified in outcrops within the western section of the study area.

The algal limestone and caliche layers of the Kimbal Limestone Member are readily seen north of Akron as a caprock. Here also the characteristic "mortar beds", which are calcareous sandstones of the Ash Hollow Member, can be discerned. Even though the Ogallala Formation 
Location SW, NW, NW, Sec. 36, T. 3N., R. 53 W.

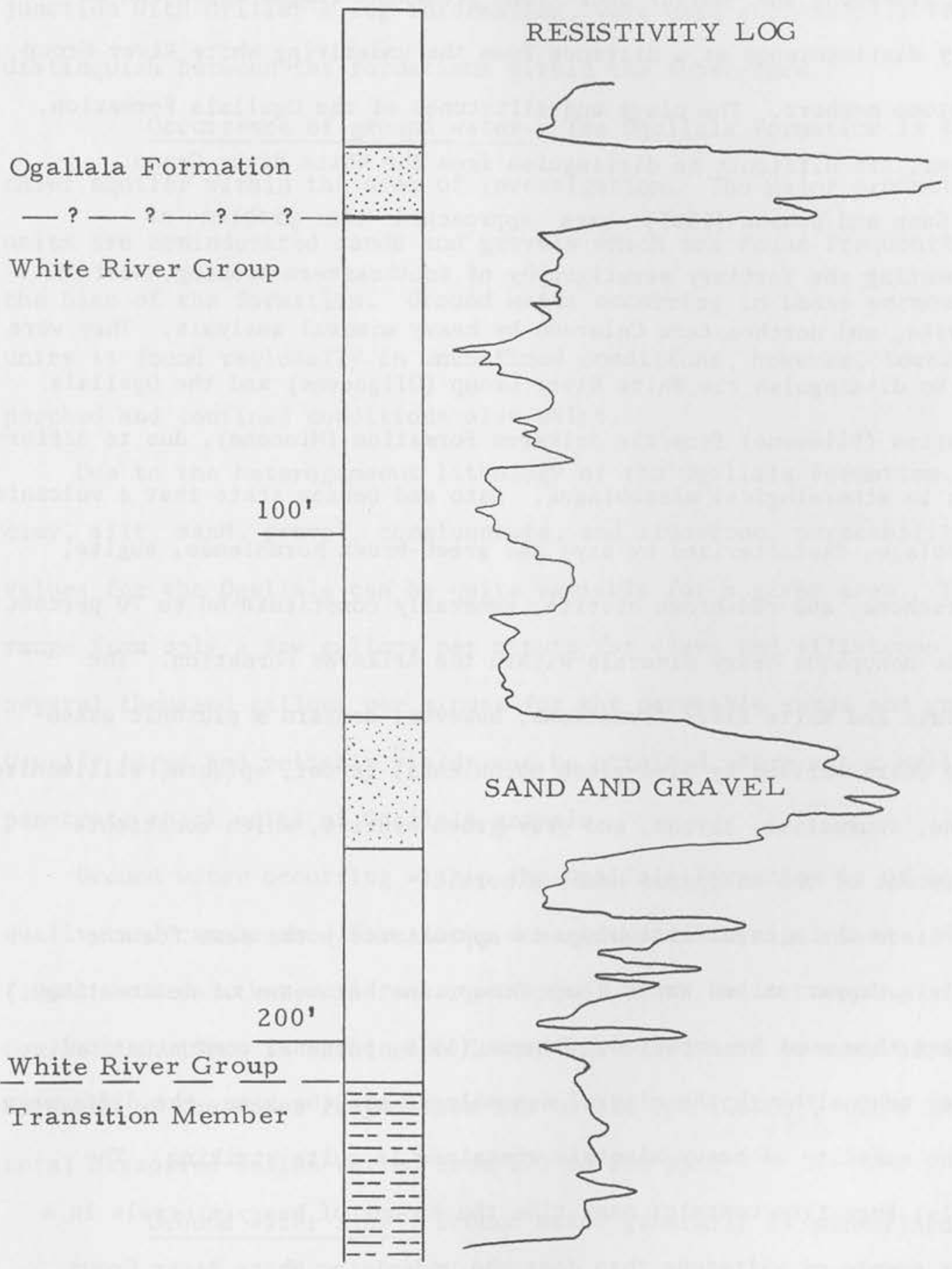

(Modified from Nelson, Haley, Patterson, and Quirk, 1968)

Figure 41. Electric $\log$ showing a characteristically high resistivity for the White River channel deposits. 
is only 17 to 30 feet thick along the escarpment northwest of Akron, the algal limestone and "mortar beds" form prominent ledges which can be easily distinguished at a distance from the underlying White River Group siltstone members. The clays and siltstones of the Ogallala Formation, however, are difficult to distinguish from the White River Group.

Sato and Denson (1967) have approached the problem of delineating the Tertiary stratigraphy of southeastern Wyoming, western Nebraska, and northeastern Colorado by heavy mineral analysis. They were able to distinguish the White River Group (01igocene) and the Ogallala Formation (Pliocene) from the Arikaree Formation (Miocene), due to differences in mineralogical assemblages. Sato and Denson state that a volcanic assemblage, characterized by oxy- and green-brown hornblende, augite, hypersthene, and red-brown biotite, generally constitute 60 to 70 percent of the nonopaque heavy minerals within the Arikaree Formation. The Ogallala and White River Formations, however, contain a plutonic assemblage characterized by blue-green hornblends, garnet, epidote, sillimanite, sphene, tourmaline, zircon, and gray-green biotite, which constitute 55 percent of the nonopaque heavy minerals.

Since the mineral assemblage is approximately the same for the Ogallala Fromation and White River Group, another means of delineating between them must be employed. Denson (1970, personal communication) states taht although the mineral assemblages are the same, the difference in the quantity of heavy minerals contained is quite striking. The Ogallal Formation contains many time the amount of heavy minerals in a given sample of siltstone than does the underlying White River Group. This disparity in the quantity of heavy minerals contained is readily apparent when the siltstones are investigated by means of a hand lens; and therefore, this method can give rapid identification during field investigations. 
Electrical resistivity and gamma geophysical well logs, in conjunction with driller's log information, were used successfully to distinguish between the formations within the subsurface. Occurrence of ground water - The Ogallala Formation is the chief aquifer within the area of investigation. The major producing units are nonindurated sands and gravels which are found frequently near the base of the formation. Ground water occurring in these permeable units is found regionally in unconfined conditions; however, locally perched and confined conditions also exist.

Due to the heterogeneous lithology of the Ogallala Formation, e.g., clay, silt, sand, gravel, conglomerate, and limestone, permeability values for the Ogallala can be quite variable for a given area. Yields range from only a few gallons per minute for clays and siltstones to several thousand gallons per minute for the permeable sands and gravels. Usually large and reliable yields can be obtained where water wells penetrate thick units of Ogallala gravels.

Ground water occurring within the Ogallala Formation is of good quality and can be used for stock, domestic and municipal uses. McGovern (1964) states that all water sampled from wells tapping the Ogallala aquifers in Washington County was rated hard or very hard. Hardnedd of the water ranged from 112 to $328 \mathrm{ppm}\left(\mathrm{CaCO}_{3}\right)$, while the total dissolved solids varied from 170 to $550 \mathrm{ppm}$.

Ground water flow - Ground water generally is unconfined within the Ogallala Formation. Due to the easterly slope of the water table (see figure 42), ground water flows in an east-northeast direction into the states of Nebraska and Kansas. The only means of recharge to the Ogallala Formation is by the infiltration of precipitation or surface waters. 


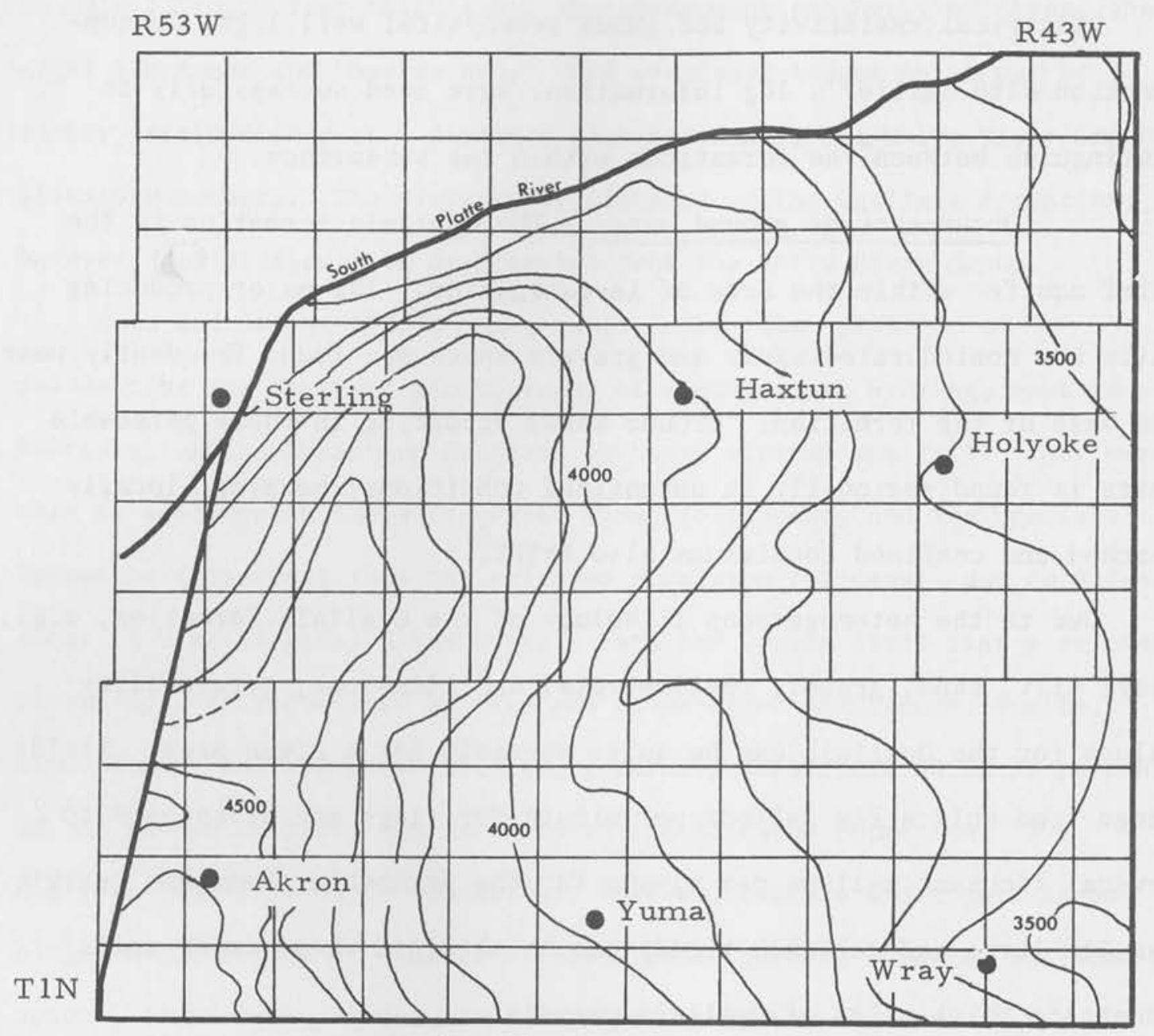

(Adapted from Woodward-Clyde-Sherard and Associates, 1966, Bjorklund and Brown, 1957, and Colorado Ground Water Basic-Data Rielease No. 20, 19691.

$$
\begin{aligned}
& \text { Contour Interval }=100 \text { feet } \\
& \begin{aligned}
\text { Datum }= & \text { Mean Sea Level } \\
& =\text { Boundary of the Study Area }
\end{aligned}
\end{aligned}
$$$$
0 \quad \text { Scale }
$$

Miles

Figure 42. Water table map of the Ogallala Formation (1965). 
Since it has a wide areal extent, ground water within the Ogallala Formation can recharge bedrock units wherever the permeability and piezometric conditions for subsurface discharge exist. Ground water flow into the underlying bedrock occurs wherever permeable units within the Ogallala Formation, containing a higher piezometric head, are in direct contact with the "porous zone" and channel deposits of the White River Group or with the sands of the Transition Member. Ground water discharging from the Ogallala Formation into the channel deposits of the White River Group or into the sands of the Transition Member will flow north-northwest to the South Platte River.

Continuity - The Ogallala is a heterogeneous formation composed of clay, silt, sand, conglomerate and limestone. Although certain units, such as the algal limestone, are reported to be widespread, there are no units which were found by the writer to be continuous throughout the entire area of investigation. In describing the extensive caprock algal limestone, Moore (1963) states that this limestone is not a single continuous unit, but is instead a series of three or four lenticular beds.

Strata within the Ogallala Formation which are most distinguishable on geophysical well logs for local correlation are the sands, gravels, limestones, and sandstones. Due to their lithologic nature and the fresh water contained, the algal limestone and permeable sands and gravels register high readings on the resistivity well logs (see figure 43). Although the sands and gravels can be found anywhere vertically within the section, they are more commonly found near the base of the formation (see figure 37 ). 
Peorian Loess and Dune Sand - The Peorian Loess contains unconsolidated silt sized particles deposited by winds during the Wisconsin age of the Pleistocene. The loess blankets much of the surface alluvial and bedrock units, and can attain thicknesses up to 60 feet within the study area. Slopes of loess are characteristically able to maintain almost verticle angles when dry. This is especially apparent along highway road cuts. Also common in loess is the development of columnar jointing in the zones nearest the surface.

Dune sand deposits are most prevalent in the eastern portion of the study area, north of Wray. Together with the Peorian Loess, they cover approximately 60 percent of the land surface. Winds blowing over the flood plain of the South Platte during Lake Pleistocene and Recent times picked up sane and deposited it over the area. Due to the greater grain size, a wind of higher velocity is indicated for the dune sand deposition. Cardwe11 and Jenkins (1963) state that topographically the dunes range from a series of low hills having relatively flat crests, separated by saddles, to irregular sand hills having a maximum local relief of about 170 feet. The dominant northwest trend in the dune hill geometry is quite evident in air photographs.

A discussion on the occurrence of ground water within the Peorian Loess and dune sand has been omitted due to the fact that they are usually found above the water table. Dune sands are important, however, since they possess a high permeability and thus aid in the recharge of ground water supplies. Peorian Loess on the other hand, is relatively impermeable and retards the infiltration of water to the water table. 


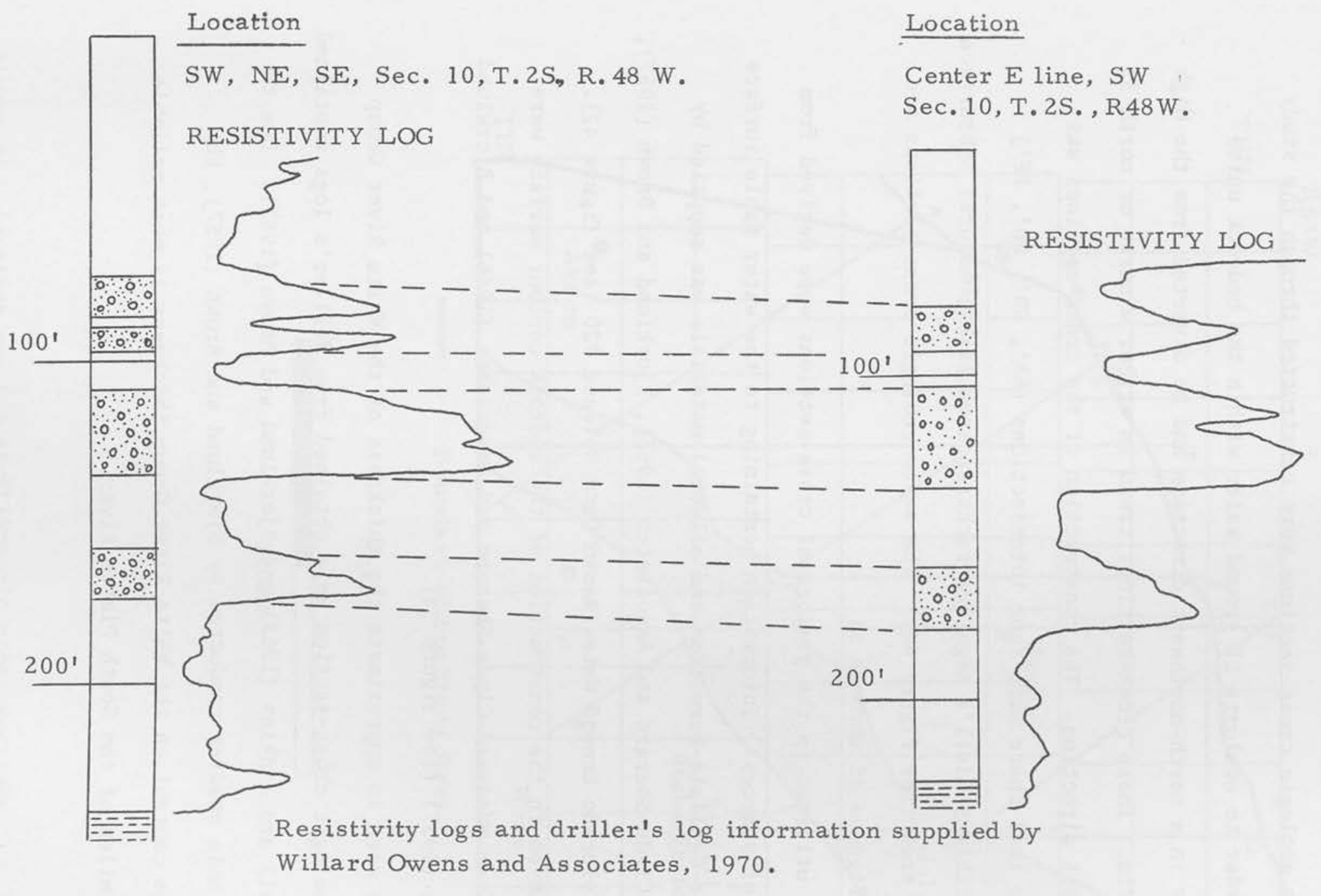

Figure 43. Electric logs, showing the local correlation of gravel lenses within the Ogallala Formation in the subsurface. 


\section{Geologic Cross-Sections}

Seven geologic cross-sections were constructed through the study area in order to evaluate if ground water within the bedrock units could flow in a north-northwest direction and be diverted from the High Plains Basin. These cross-sections trend in either a north or north 35 degrees west direction. The construction of the cross-sections was devised so that there were four intersections ( $\mathrm{AA}^{\prime}, \mathrm{BB}^{\prime}, \mathrm{DD}^{\prime}, \mathrm{FF}^{\prime}$ ) located within Reddell's negative recharge area, i.e., natural subsurface discharge area (see figure 44). The seven geologic cross-sections are given in figures 45 through 51 .

Data utilized in the geological cross-sections were derived from a number of sources. Information pertaining to the water table surface within the Ogallala Formation and alluvial materials was supplied by Woodward-C1yde-Sherard and Associates (1966), Bjorklund and Brown (1957), and the Colorado Ground Water Basic Data Release \#20 (see figure 42). Data employed in the construction of the bedrock contour surface were derived from Woodward-Clyde-Sherard and Associates (1966) and Bjorklund and Brown (1957) (see figure 34).

Data used to approximate the thickness of the White River Group in the geologic cross-section were obtained from driller's logs contained in Cardwe1l and Jenkins (1963) and Bjorklund and Brown (1957). Due to the test hole studies conducted by Bjorklund and Brown (1957), the subsurface control on the White River Group thickness is most reliable within 5 miles of the South Platte River. 


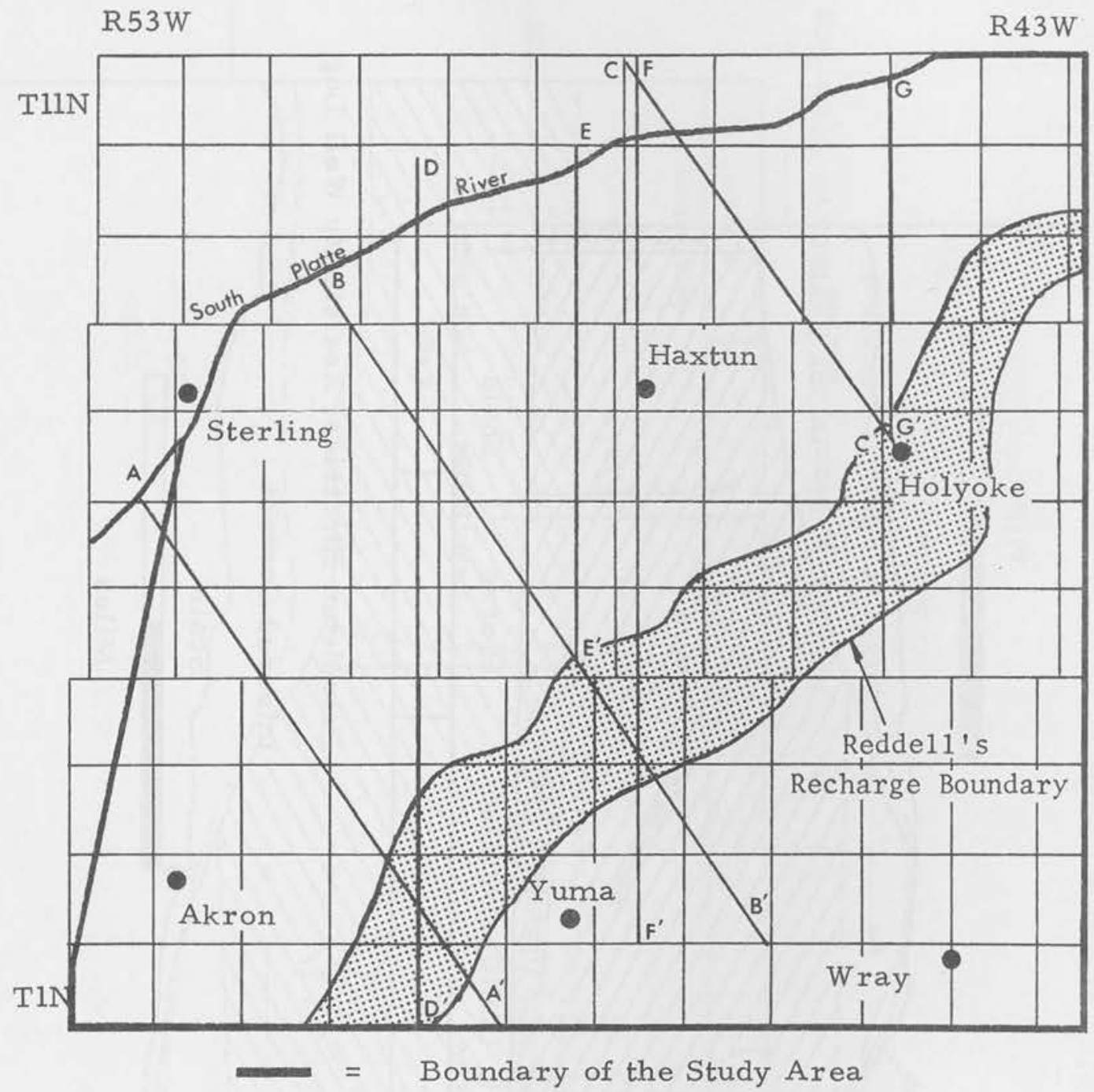

Scale

0

Miles

Figure 44. Location map for stratigraphic cross-sections. 


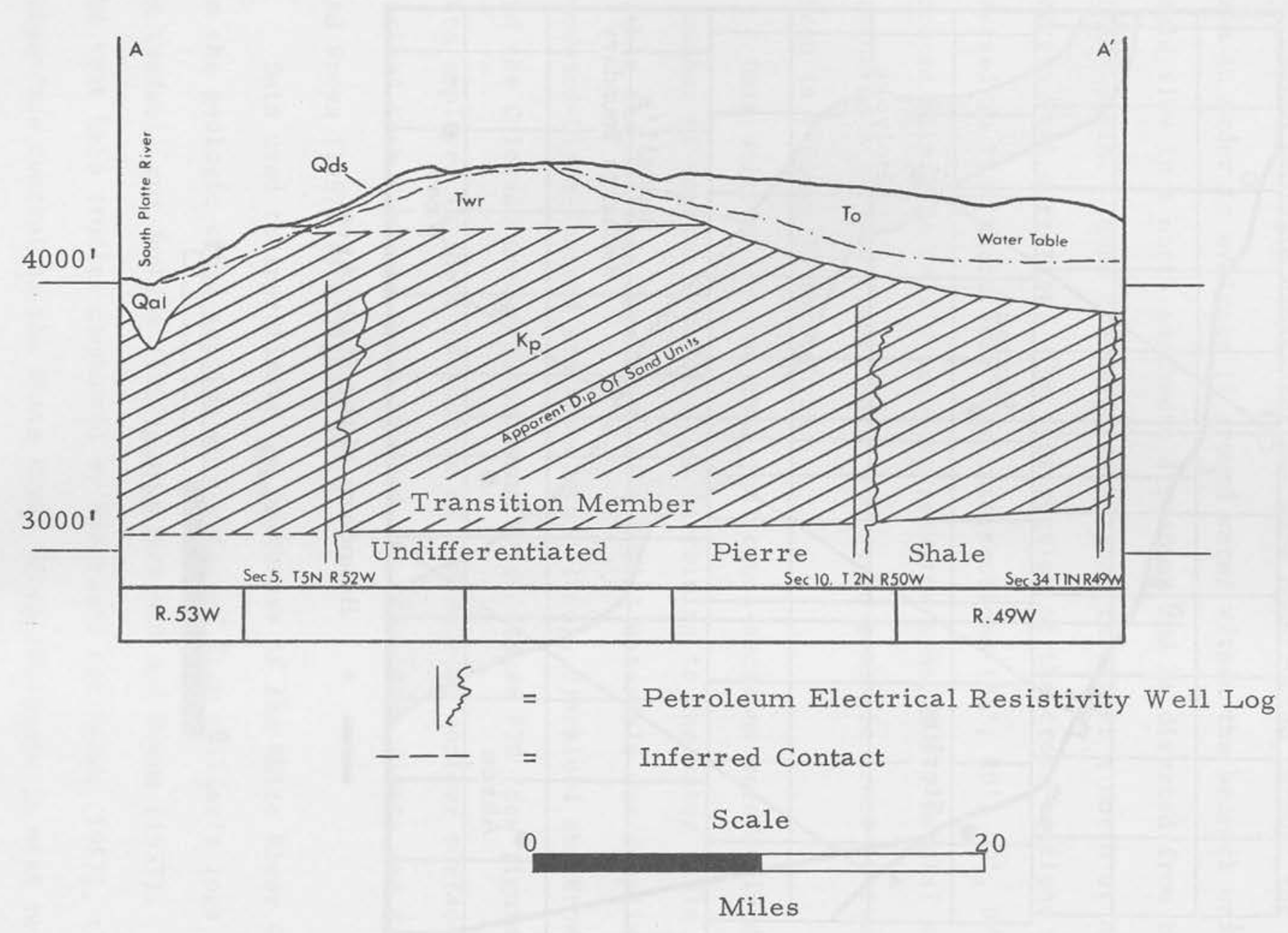

Figure 45. Cross-section A-A', looking to the northeast. 


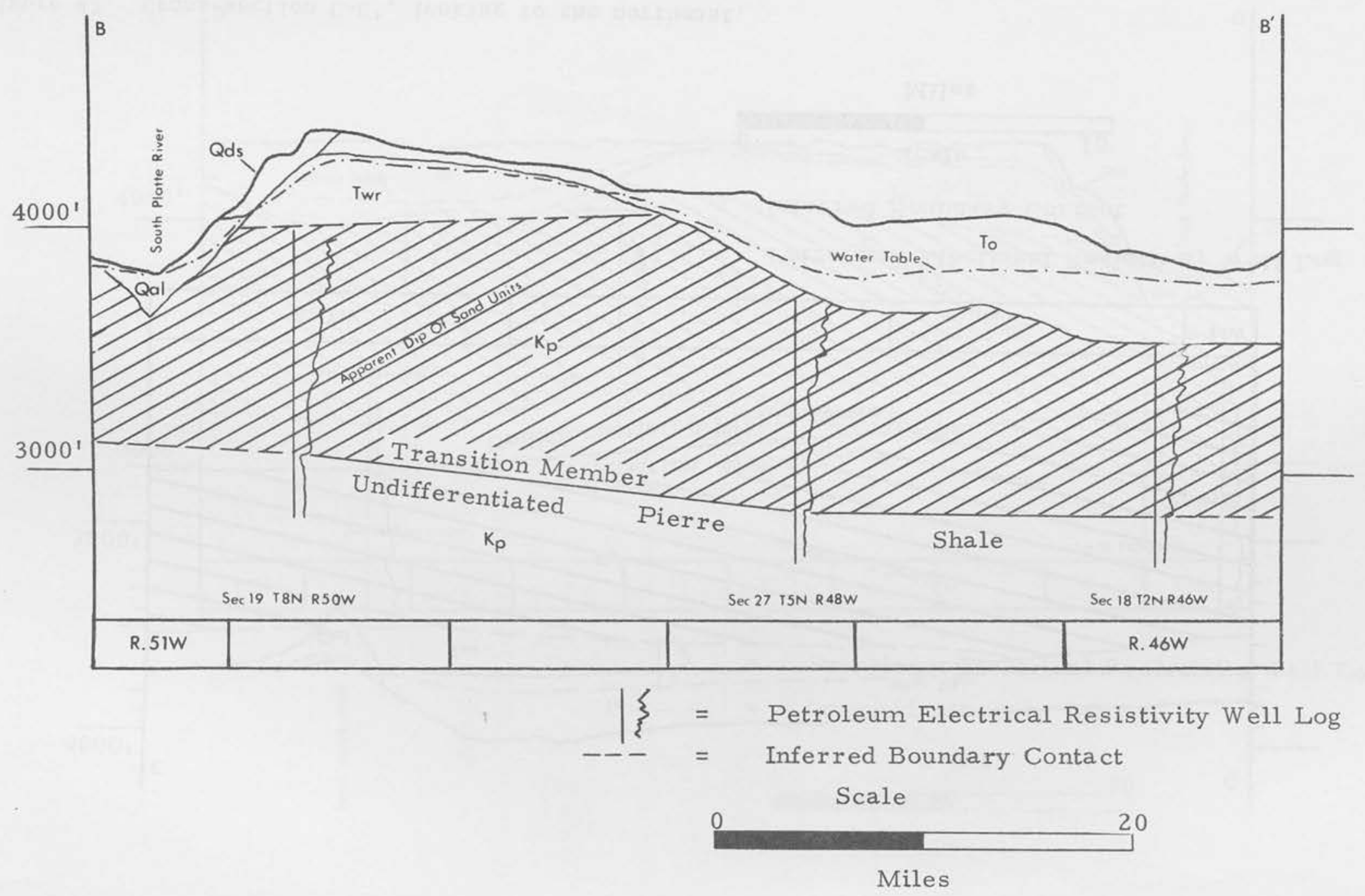

Figure 46. Cross-section B-B', looking to the north east. 


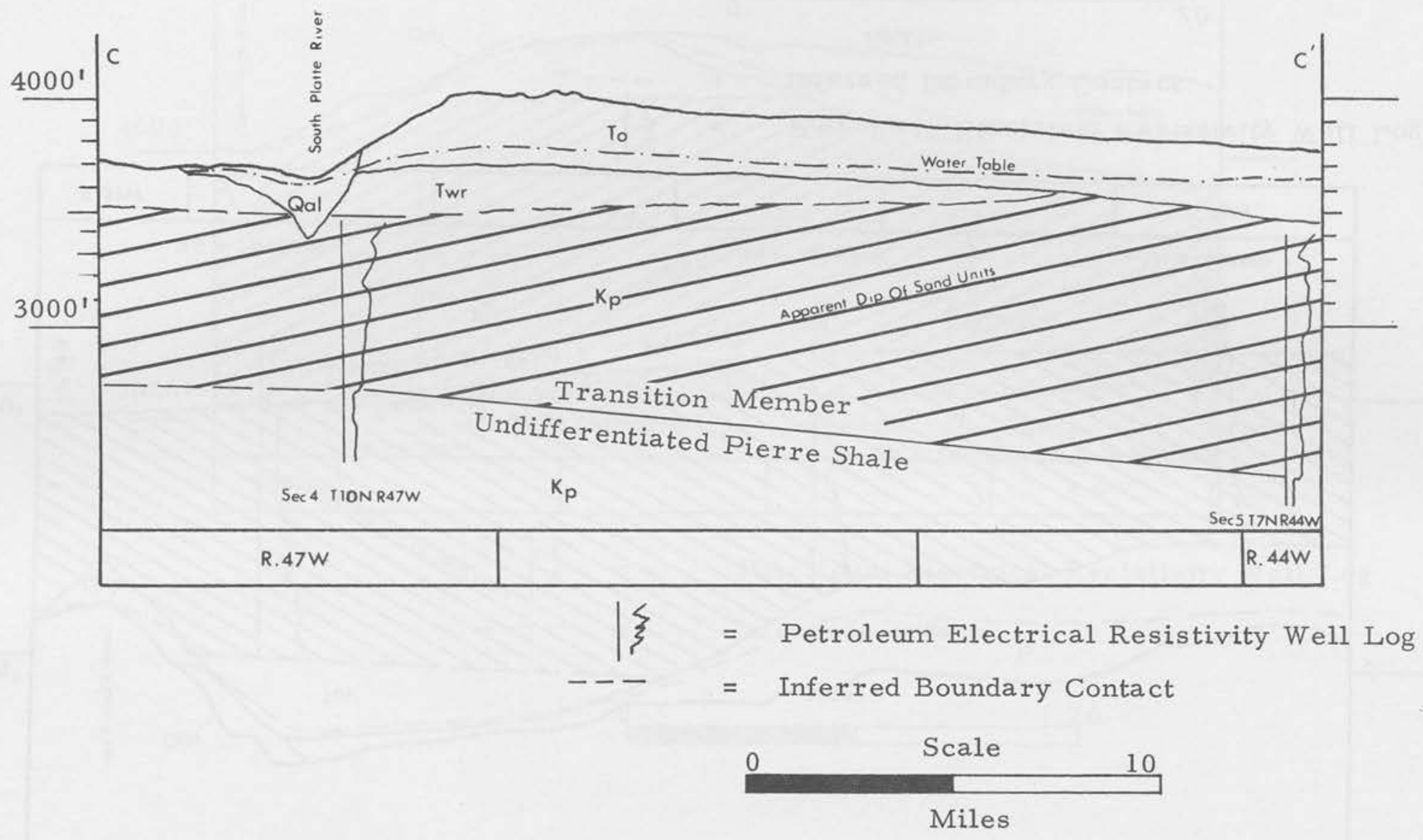

Figure 47. Cross-section $\mathrm{C}-\mathrm{C}^{\prime}$, looking to the northeast. 


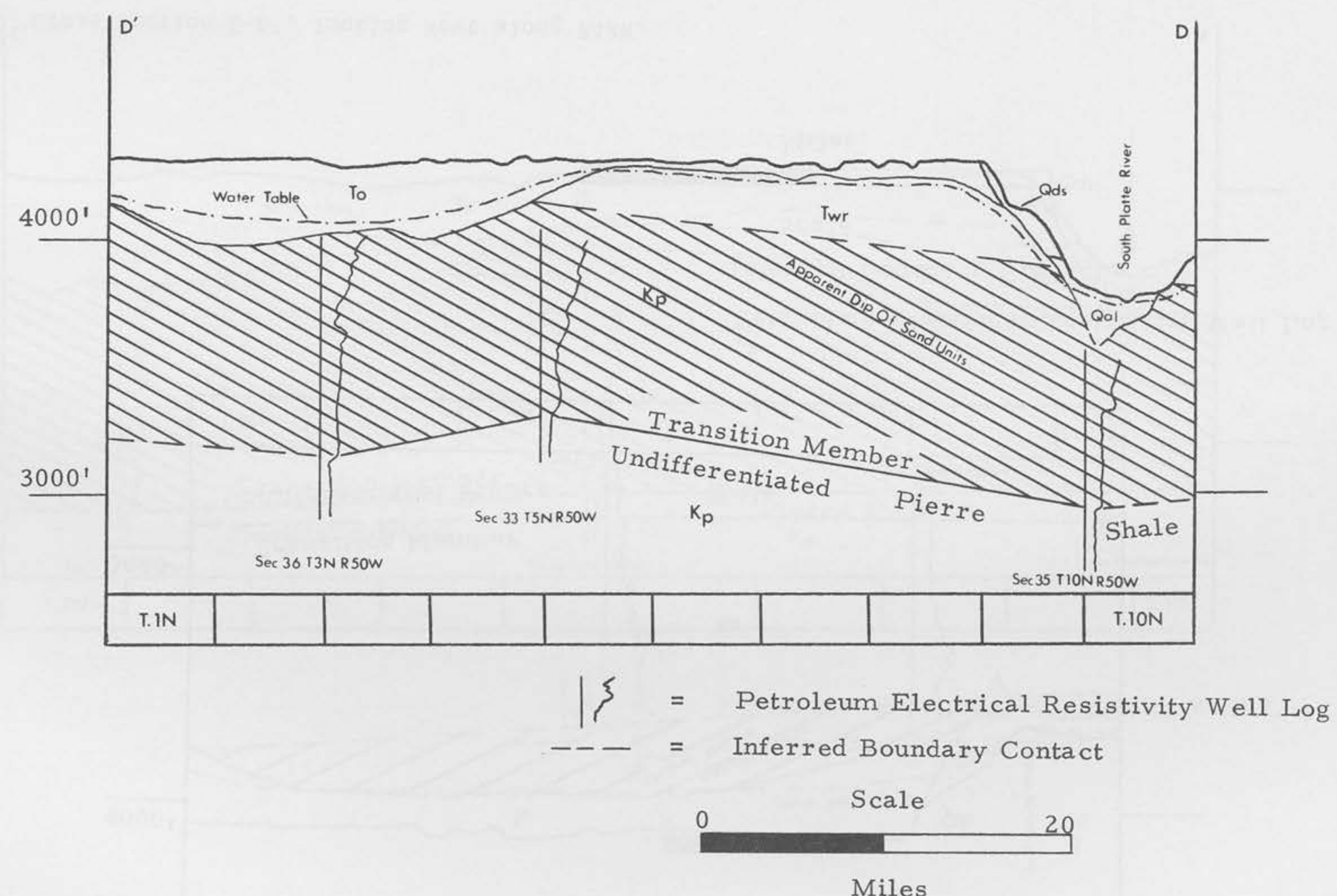

Figure 48. Cross-section D-D', looking West along R50W. 


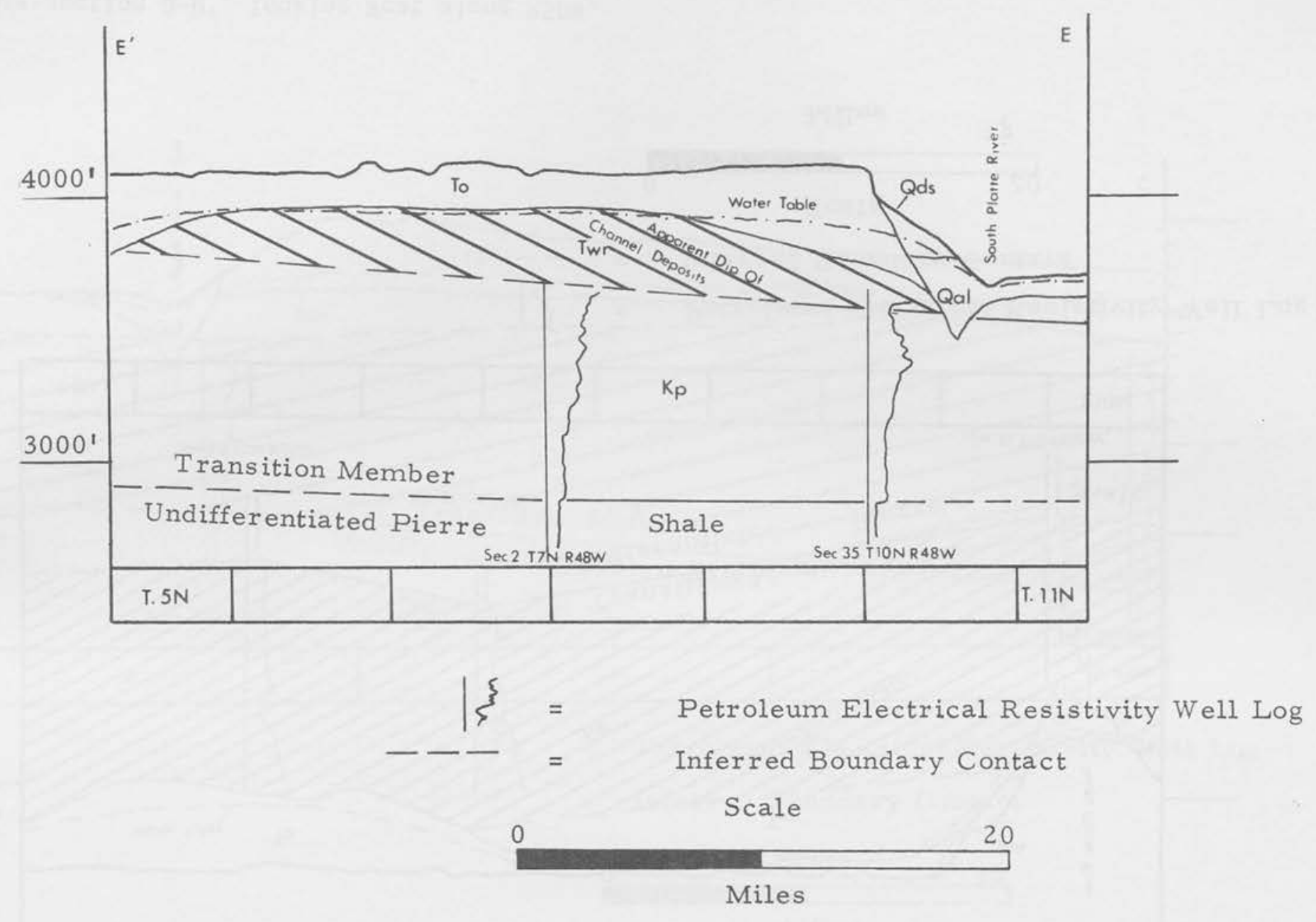

Figure 49. Cross-section E-E', looking West along R48W. 


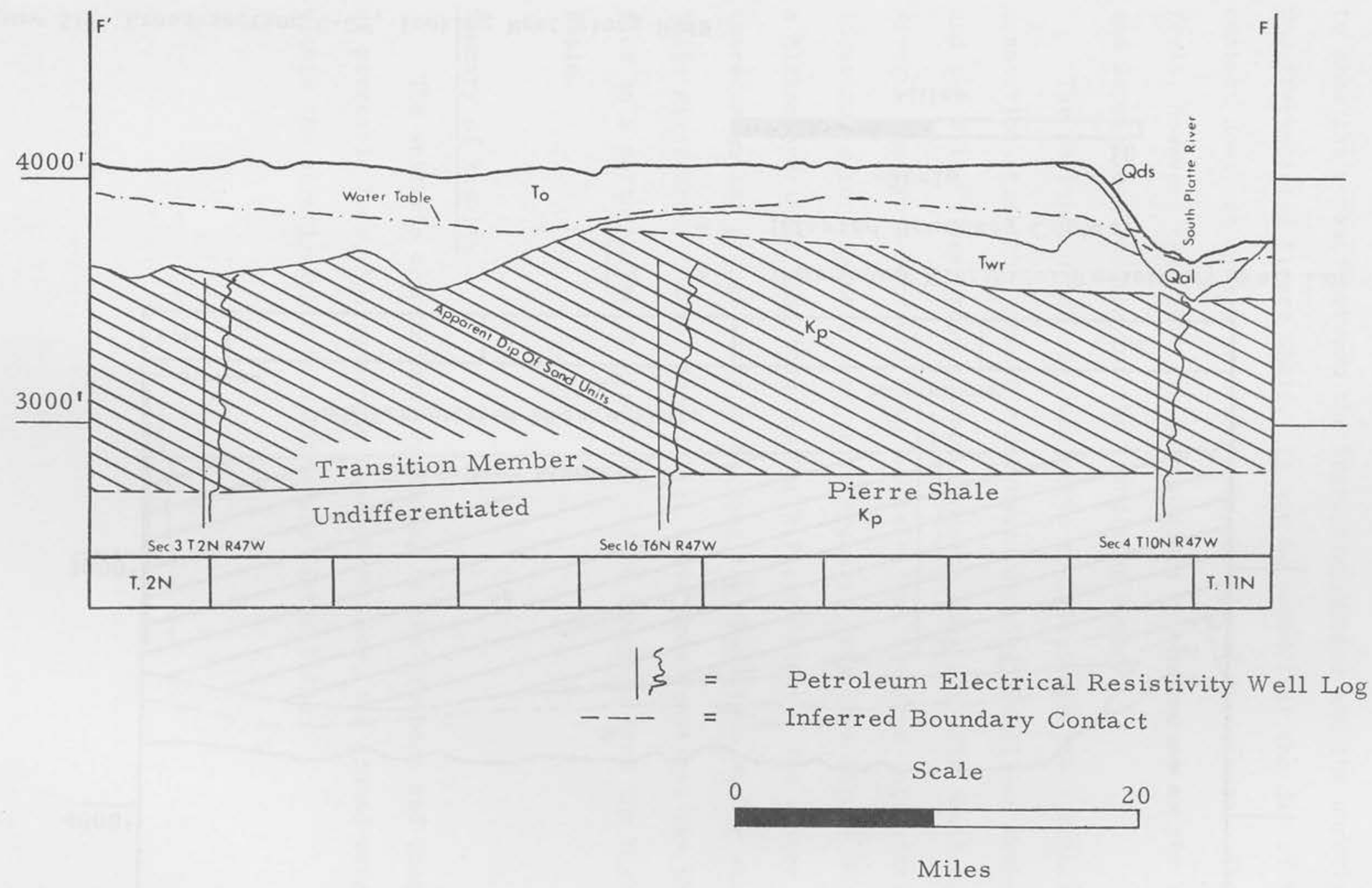

Figure 50. Cross-section F-F', looking West along R47W. 


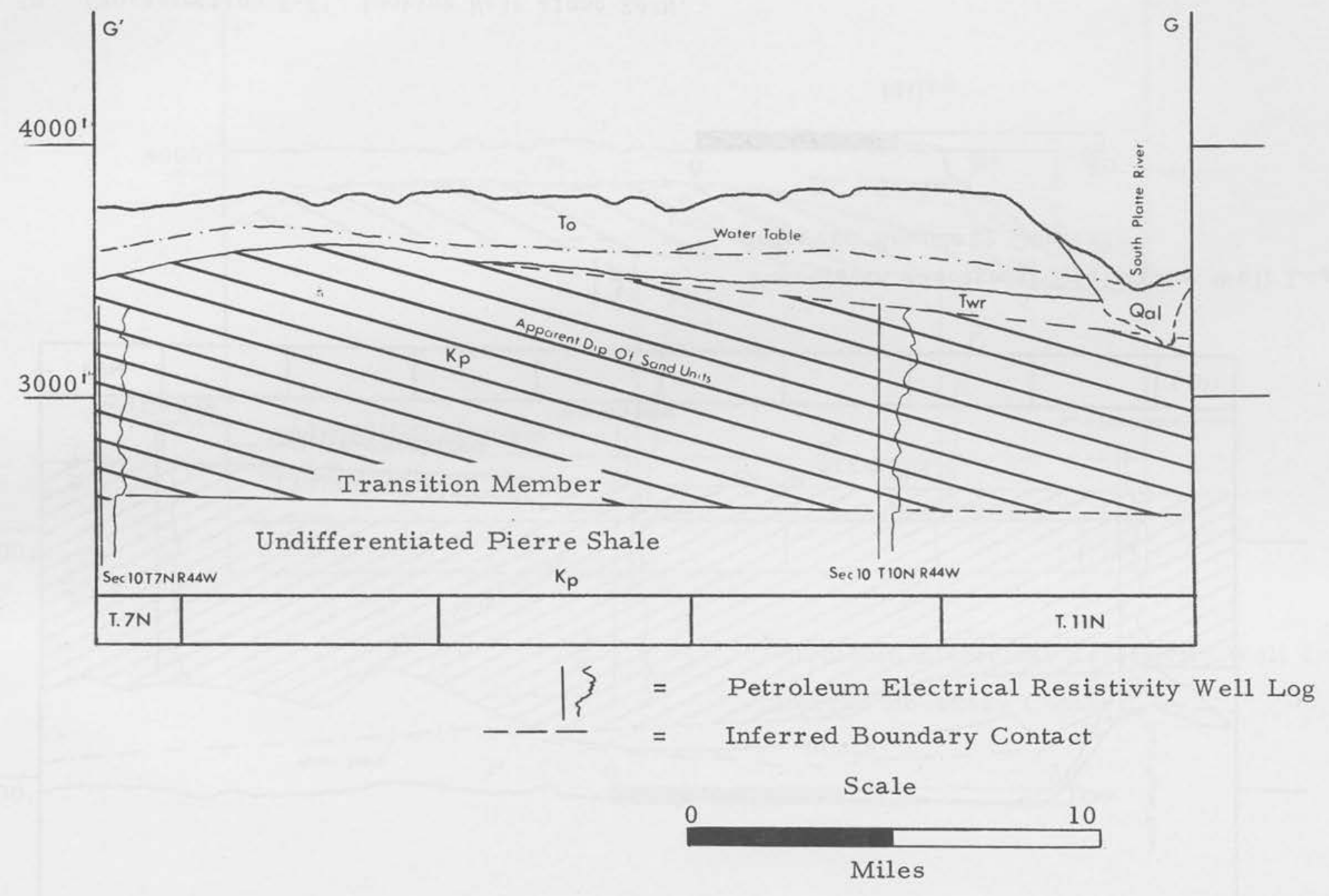

Figure 51. Cross-section G-G', looking West along R44W. 
Electric logs from oil field wells were used in the cross-sections to show the contact between the Transition Member and the underlying Undifferentiated Pierre Shale. It may be noted that the dip of the contact does not always coincide with the dip of the strata. The writer feels, however, that this can be explained by variations in the erosional and depositional history of the Transition Member.

The geologic cross-sections serve to illustrate the hydraulic connection which the permeable northward dipping Transition Member sands and the White River Group channel deposits have with the South Platte River. The cross-sections also indicate that the four intersection locations within Reddell's negative recharge area (see figure 44) contain a higher hydraulic head than the South Platte River. The writer concludes, therefore, that ground water recharging the Transition Member sands of White River Group channel deposits at these four locations can physically flow in a north-northwest direction and be diverted from the High Plains Basin.

Summary of Results

The writer's conclusions pertaining to the presence and continuity of permeable beds, hydrogeologic characteristics, and ground water flow within the stratigraphic formations are listed below: 


\section{Transition Member}

1) The Transition Member of the Pierre Shale is composed of alternating beds of sand and sandy shale that underlie the entire study area

2) Sand content, and probably permeability, within the member apparently increases in a vertical direction

3) Individual lenticular sand beds, up to 25 feet thick, dip gently to the north

4) Locally the Transition Member can be of aquifer importance. Regionally the Transition Member should be considered of significance in ground water storage and flow

5) Well yields as high as 100 gallons per minute are reported in sands within the Transition Member

6) Ground water within the sandy Transition Member usually is under artesian conditions

7) Local1y, ground water recharge into and/or discharge from the Transition Member most likely occurs in bedrock valleys. Here, saturated Tertiary channel deposits are in direct contact with the sands of the Transition Member

8) Ground water within the Transition Member which is hydraulically connected with the topographically higher than the South Platte River can flow in a north-northwest direction from the High Plains Basin into the South Platte River

\section{White River Group}

1) The White River Group contains two aquifers, the channel deposits and the "porous zone", which can yield moderate amounts of water

2) The channel deposits occur in the lower section of the White River Group and dip gently to the north

a) Ground water is usually under artesian conditions

b) Ground water at higher elevations and in hydraulic connection with the South Platte River apparently flows north-northwest through the channel deposits and discharges into the river

c) Ground water recharge to the channe1 deposits is most apt to occur where the overlying White River siltstone has been removed 
3) The "porous zone" where present occurs at or near the contact with the overlying Ogalla Formation

a) Ground water generally is under unconfined conditions and is hydraulically connected with the overlying Ogallala Formation ground water flow system

b) Due to the "porous zone's" intimate hydraulic connection with the overlying Ogallala Formation, ground water is expected to flow in an east-northeast direction

$\underline{\text { Oga1lala Formation }}$

1) The Ogallala Formation is the chief aquifer within the area of investigation

2) The more permeable units, the sands and gravels, are found more frequently near the base of the formation

3) Ground water generally exists under unconfined conditions and flows in an east-northeast direction

4) The greatest amount of ground water loss from the formation occurs wherever the permeable sands and gravels are in direct contact with underlying bedrock units containing a lower piezometric head

5) Ground water discharging from the Ogallala Formation to the channel deposits of the White River Group and the sands of the Transition Member apparently flows to the north-northwest and is diverted from the High Plains Basin

\section{Conclusions}

Only two units within the bedrock are thought to be capable of water transfer from the northern portion of the High Plains Ground Water Basin to the South Platte River. They are the channel deposits of the White River Group and the sands in the Transition Member of the Pierre Shale. Locally, these bedrock units are utilized as an aquifer source for stock, domestic, and occasionally municipal purposes. Wells tapping artesian aquifers were reported to yield as high as 350 gallons per minute for the White River Group channel deposits and 100 gallons per minute for the sands within the Transition Member. 
Neither of these permeable bedrock units are continuous laterally throughout the entire study area. The channel deposits of the white River Group are found most often near the base of the section in bedrock paleostream channels eroded into the Transition Member or White River Group. Individual sand beds within the Transition Member occur most frequently near the top of the section. These sand beds usually can not be traced over five miles in the subsurface.

Where favorable piezometric conditions exist, ground water is thought to recharge the bedrock units in locations where they are directly overlain by the saturated sands and gravels of the Ogallala Formation. Such an area where ground water apparently recharges the underlying bedrock units was designated by Redde11 (1967).

In order to evaluate if ground water discharging into the bedrock units within Redde11's negative recharge area can be diverted in a northnorthwest direction from the High Plains Basin, seven geologic crosssections were constructed through the study area. The cross-sections were oriented in a manner so that four inter-sections occurred within Reddel1's negative recharge area.

Analysis of the geologic cross-sections indicated that due to a higher hydraulic head and to the lateral permeability afforded by the northward dipping channel deposits of the White River Group and Transition Member sands, ground water could be naturally diverted from the High Plains Basin in a north-northwest direction (see figure 44). 


\section{SUMMARY OF RESULTS AND CONCLUSIONS}

I. Magnitude of groundwater flux through bedrock in three designated groundwater basins in Colorado (as determined by digital computer model studies):

A. Kiowa-Bijou Basin. Groundwater flows from the Fox Hills Sandstone into the alluvium of the Kiowa-Bijou Basin at a rate of approximately 19,000 acre-feet per year. This figure is thought to have an accuracy of $\pm 15,000$ acre-feet/year.

B. Black Squirrel Basin. Groundwater flows from the alluvium of the Black Squirre1 drainage into the underlying Fox Hills Sandstone at a rate of approximately 5,350 acre-feet/year. This figure is thought to have an accuracy of $\pm 1,600$ acrefeet/year.

C. High Plains Basin. Groundwater flows from the Ogallala Formation (surface aquifer) in the High Plains Basin into the underlying sandstones of the White River Group and probably into the sandstones of the Pierre Shale Transition Zone at a rate of approximately 75,000 acre-feet per year. This figure is considered to be conservative.

II. Principles and methods to apply for estimation of interbasin groundwater flux:

A. The principles governing groundwater motion can be applied in a qualitative sense to achieve a reconnaissance-level evaluation of interbasin groundwater flux.

For example, groundwater flow potential is directly related to the elevation of ground water levels in one basin relative 
to the water levels in adjacent basins. If the lower boundary (bedrock) of a basin contains some strata which are relatively permeable compared to the rest of the bedrock, and if these relatively permeable strata are exposed beneath saturated alluvium at a different elevation in one basin than in the adjacent basin, then interbasin groundwater flow can be anticipated. The direction of the flow can be determined by a simple comparison of water levels near the areas where permeable bedrock strata outcrop in the adjacent basins.

B. A more detailed and reliable method for determining interbasin transfer of groundwater is the application of a numerical model which describes the flow of groundwater within a given basin. The model described in this report is based on Darcy's law and the mass continuity equation. Data required for the model are hydraulic conductivity, storage coefficient, and saturated thickness of the aquifer, plus water level elevations and net groundwater withdrawal.

The model has been applied to the analysis of interbasin groundwater flow by assuming that no leakage occurs at the base of the alluvial aquifer. Where leakage does occur, the model produces anomalous results in the form of erroneous water level elevations. The magnitude of the anomalies can be used to calculate the rate of the interbasin groundwater flux.

III. Data requirements for the analysis of interbasin groundwater flux:

A. Intrabasin studies: Analysis techniques such as the one presented in IIB above require data on the geometry and physical properties of the aquifer in a basin plus basic hydrologic 
information such as surface recharge/discharge data and water level elevations.

The most critical data for the successful application of an intrabasin model study are the water level elevations. Errors in water level data produce errors of equal magnitude in the results of the model analysis.

Errors in water level data are common for several reasons:

1. Many wells penetrate more than one aquifer. The water level in such a well will reflect the composite effect of the various hydraulic flow potentials. (The model analysis, however, assumes a single unconfined aquifer containing nearly vertical equipotential planes.)

2. Shallow wells may penetrate a perched groundwater body and exhibit a water level which is unrelated to the major alluvial groundwater aquifer.

3. Topographic control may be inadequate. If elevation at the well head is simply estimated from a topographic map, an error of several feet or more will be likely. The water level elevation at the site will consequently include this error.

4. Water levels in some areas have large seasonal fluctuations. For application in model studies, the water level data should reflect flow conditions in the aquifer at a point in time. Hence, water levels measured at different points within the basin may be in error relative to one another if the levels fluctuated during the period of measurements. 
B. Interbasin studies: Analysis techniques such as the one described in section IIA above require data on regional topographic, geologic, and hydrologic conditions.

The transfer of groundwater through the bedrock from one basin to another is an effect which occurs only where hydraulic and geologic conditions are balanced in such a way as to permit the phenomenon to occur.

1. Geologic conditions: The geologic data required to evaluate interbasin groundwater transfer with the regional perspective are both stratigraphic and structural in nature. The primary geologic conditions which permit interbasin groundwater flux to occur are:

a. variable stratigraphy, e.g., alternating sandstones and shales which result in anisotropy of permeability within the bedrock.

b. lithologic continuity, i.e., the relatively permeable bedrock strata must be continuous in lateral extent from one basin to another. Fault displacement or facies changes are the most common causes of lithologic discontinuities. c. structural configuration, i.e., the relatively permeable and continuous bedrock strata ordinari1y must be inclined or folded in such a way as to produce exposures of the formation in one or more adjacent basins.

2. Topographic and hydrologic conditions: Regional topography is significant in evaluation of interbasin 
groundwater flux in the fact that groundwater elevations are normally directly related to 1 and surface elevations. Where adjacent groundwater basins are at substantially different topographic elevations, the flux of groundwater between the basins can be expected to occur from the higher basin to the lower.

Regional water table configurations are the principal hydrologic data to consider in assessing interbasin groundwater flux. The condition necessary for groundwater transfer is a difference in water level elevations between adjacent basins measured at the points of exposure of a connecting relatively permeable bedrock formation. 


\section{BIBLIOGRAPHY}

Anderman, G. G. and Ackman, E. J.; 1963, Structure of the DenverJulesburg Basin and Surrounding Areas: Guidebook to the Geol. of the Northern Denver Basin and Adjacent Uplifts; Rocky Mt. Assoc. of Geologists, p. 170-175.

Bibby, R., 1969; Flow Between the Confined Aquifer of the Fox Hills Sandstone and the Alluvial Aquifer in the North Kiowa-Bijou District, Colorado; M. S. Thesis, Department of Civil Engineering, Colorado State University.

Bibby, R., 1971: Statistical Error Analysis of Ground Water Systems; Ph.D. Dissertation, Colorado State University.

Bibby, R. and D. K. Sunada, 1971; Mathematical Model of a Leaky Aquifer, Journal of Irrigation and Drainage, ASCE, Vo1. 97, No. IR3.

Bibby, R. and D. K. Sunada, 1971; Statistical Error Analysis of a Numerical Model of Confined Ground Water Flow, International Symposium on Stochastic Hydraulics, Pittsburgh.

Bittinger, M. W., 1967; Simulation and Analysis of Stream-Aquifer Systems; Ph. D. Dissertation, Utah State University, Logan, Utah.

Bittinger, M. W., Duke, H. R., and Longenbaugh, R. A., 1967; Mathematical Simulations for Better Aquifer Management, Publication No. 72 of the I.A.S.H., Symposium of Haifa, pp. 509-519.

Bittinger, M. W., and Stringham, G. E., 1963; A Study of Phreatophyte Growth in the Lower Arkansas River Valley of Colorado, Colorado Agricultural Experiment Station, CER63MWB-GES6.

Bjorklund, L. J. and Brown, R. F.; 1957; Geology and Groundwater Resources of the Lower South Platte River Valley Between Hardin, Colorado, and Paxton, Nebraska: U. S. Geo1. Survey, Water Supply Paper 1378, 431p.

Brown, R. W., 1943; Cretaceous-Tertiary Boundary in the Denver Basin, Colorado, Geol. Soc. Amer. Bull., Vol. 54, pp. 55-86.

Cardwe11, W. D. E., and Jenkins, E. D., 1963; Ground-Water Geology and Pump Irrigation in Frenchman Creek Basin Above Palisade, Nebraska, U. S. Geological Survey Water Supply Paper 1577, 472p.

Code, W. E., 1943; Use of Ground Water for Irrigation in the South P1atte Valley of Colorado, Bulletin 483, Colorado Agricultural Experiment Station, Fort Collins, Colorado.

Code, W. E., 1961; Ground Water and the Bijou Valley, Bulletin 512-S Colorado Agricultural Experiment Station, Fort Collins, Colorado. 
Conrad, G. E. and Scherer, O. J., 1940; Correlation of the Formations of the Laramie Range, Hartville Uplift, Black Hills, and Western Nebraska: Nebraska Geological Survey Bulletin, No. 13, 52p.

Dane, C. H., and Pierce, C. W., 1936; Dawson and Laramie Formations in the Southeast Part of the Denver Basin, Colorado; Amer. Assoc. of Petroleum Geologists Bu11., Vo1. 20, pp. 1308-13-28.

Darton, N. H., 1905; Preliminary Report on the Geology and Underground Water Resources of the Central Great Plains: U. S. Geol. Survey, Prof. Paper 32, 432 p.

DeGraw, H. M., 1969; Subsurface Relations of the Cretaceous and Tertiary in Western Nebraska: Nebraska Geol. Survey, Open File Report, 140 p.

Denson, N. M., 1969; Distribution of Nonopaque Heavy Minerals in Miocene and Pliocene Rocks of Central Wyoming and Parts of Adjacent States: U. S. Geological Survey, Prof. Paper 650-C, p. C25-C32.

Denson, N. M., 1970; Personal Communication, Stratigrapher, U. S. Geol. Survey, Federal Center, Denver, Colorado.

Duke, H. R. and Longenbaugh, R. A., 1966; Evaluation of Water Resources in Kiowa and Bijou Basins, Colorado; Colorado State University, CER66HRD-RAL19.

Dunn, H. L., 1959; Sandstones of the Pierre Formation in the Denver Basin: Symposium of Cretaceous Rocks of Colorado and Adjacent Areas; Rocky Mountain Association of Geologists, p. 132-136.

Erker, H. W., and Romero, J. C., 1967; Ground Water Resources of the Upper Black Squirrel Creek Basin, E1 Paso County, Colorado; Prepared for Colorado Ground Water Commission by Division of Water Resources, Office of State Engineer, Ground Water Section, Denver, Colorado.

Eshett, A., and Longenbaugh, R. A., 1965; Mathematical Model for Transient Flow in Porous Media; Colorado State University, CER65RAL-AE59.

Fennerman, N. M., 1931; Physiography of Western United States; McGrawHil1 Book Co., 534 p.

Finlay, G., 1916; Colorado Springs Folio, Colorado; U. S. Geo1. Survey Folio No. 203.

Fisk, C. C., 1965; Status Report on Ground Water Investigations in the Black Squirrel Valley: Prepared for Squirrel Creek- Ellicott Water Users Association, E1 Paso County, Colorado.

Fogarty, C. F., 1952; Subsurface Geology of the Denver Basin, Colorado; Doctors Thesis, Colorado School of Mines.

Galbreath, E. C., 1953; A Contribution to the Tertiary Geology and Paleontology of Northeastern Colorado: Paleont, Contr. Univ. Kansas, Vertebrata, art. 4, pp. 1-120. 
Geoke, J. W., 1970; The Hydrogeology of the Black Squirrel Creek Basin, E1 Paso County, Colorado; M. S. Thesis, Department of Geology, Colorado State University, Fort Collins, Colorado.

Goodier, J. T., 1960; Report on Geology and Ground Water of Kiowa Creek, Adams County, Colorado; M. S. Thesis, Geology Department, Colorado State University, Fort Collins, Colorado.

Graybi11, F. A., 1961; An Introduction to Linear Statistical Models, Volume 1, McGraw-Hill.

Griffitts, M. O., 1949; Zones of the Pierre Formation of Colorado; Bull. Amer. Assoc. Petroleum Geologists, V. 33, N. 12, p. 2011-2028.

Henderson, J., 1920; Fox Hills Sandstone in Northeastern Colorado; Colorado Geol. Survey Bul1. 19.

Hofstra, W. E., 1970; Results of Test Drilling at the Central Great Plains Field Station Near Akron, Northeastern Colorado; U. S. Geol. Survey, Water Resources Division, Open File Report, 26 p.

Horner, W. C.; The Fox Hills-Laramie Contact in the Denver Basin, Colorado; M. S. Thesis, Department of Geology, University of Colorado, Boulder, Colorado.

Kuhn, A. K., 1968; Fox Hills Aquifer, North East Colorado; M. S. Thesis, Department of Geology, Colorado State University, Fort Collins, Colorado.

Leroy, L. W., 1944; Stratigraphy of the Golden-Morrison Area, Jefferson County, Colorado; Doctors Thesis, Colorado School of Mines, Golden, Colorado.

Lohman, S. W., 1953a; High Plains of West-Central United States, General Aspects, Chap. 4 of U. S. Cong., House Comm. Interior and Insular Affairs, Subsurface Facilities of Water Management and Patterns of Supply -- Type Area Studies, p. 70-78.

Longenbaugh, R. A., 1967; Mathematical Simulation of a Stream Aquifer System, Colorado State University, CER67-68RAL22.

Lovering, T. S., Aurand, H. A., Lavington, C. S. and Wilson, J. H., 1932; Fox Hills Formation, Northeastern Colorado; Amer. Assoc. of Petroleum Geologists Bull., Vol. 16, No. 7, pp. 702-703.

Lugn, A. L., 1939; Classification of the Tertiary System in Nebraska; Geol. Soc. of America, Bulletin, V. 50, p. 1227-1244.

Mather, K. F., Gilluly, J. and Lusk, R. G., 1927; Geology and 0il and Gas Prospects of Northeastern Colorado; U. S. Geol. Survey, Bulletin 796 , p. $65-124$. 
McConaghy, J. A. and Colburn, G. W., 1964; Records of Wells in Colorado; Colorado Ground Water Basic Data Release No. 17, Colorado Water Conservation Board.

McGovern, H. E., 1964; Geology and Ground-Water Resources of Washington County, Colorado; U. S. Geological Survey, Water Supply Paper 1777, p. $1-46$.

McGovern, H. E. and Jenkins, E. D., 1966; Ground Water in Black Squirrel Creek Valley, E1 Paso County, Colorado; U. S. Geol. Survey Hydrol. Inv. Atlas HA-236.

McLaugh1in, T. G., 1946; Geology and Ground Water Resources of Parts of Lincoln, Elbert and El Paso Counties, Colorado; Colorado Water Conservation Board Ground Water Ser. Bu11. 1, 139 p.

Moore, F. E., 1960; The Geomorphic Evolution of the East Flank of the Laramie Range, Colorado and Wyoming; Guide to the Geology of Colorado, p. 217-223.

Moore, F. E., 1960; Summary of Cenozoic History, Southern Laramie Range, Wyoming and Colorado, in Rocky Mtn. Assoc. Geologists, Guide to Geology of Colorado, Denver, pp. 217-222.

Moore, F. E., 1963; Tertiary Stratigraphy of the High Plains; Guidebook to the Geology of the Northern Denver Basin and Adjacent Uplifts; Rocky Mt. Assoc. of Geologists, p. 162-166.

Moulder, E. A., 1960; Occurrence of Ground Water in the Ogallala and Several Consolidated Formations in Colorado; Colorado Water Conservation Board, Ground Water Series, Circular 5, 8 p.

Nelson, Haley, Patterson, and Quirk, Inc., 1968; Ground Water Resources of Northwest Washington County, Colorado, 25 p.

Nolte, C. J., 1963; Potential Stratigraphic Accumulations of 0il and Gas in the Upper Cretaceous of the Denver Basin; Guidebook Field Conferences, Rocky Mountain Assoc. Geol., p. 156-161.

Orie1, S. S., 1954; Major Tectonic Elements of Colorado; A Review; Oil and Gas Fields of Colorado; Rocky Mt. Assoc. of Geologists, p. 41-46.

Rankin, C. H., Jr., 1933; Study of Well Sections in Northeast Colorado; Am. Assoc. Petroleum Groligists, Bull., V. 17, N. 4, pp. 422-432.

Redde11, D. L., 1967; Distribution of Ground Water Recharge; Technical Report, Agricultural Engineering Department, Colorado State University, $132 \mathrm{p}$.

Reichert, S. 0., 1956; Post-Laramie Stratigraphic Correlations in the Denver Basin, Colorado; Geol. Soc. of Amer. Bul1., Vo1. 67, No. 1, pp. 107-111. 
Richardson, G. B., 1915; Description of the Castle Rock Quadrangle, Colorado; U. S. Geol. Survey, Folio 198.

Romero, J. C., 1965; Geologic Control of Ground Water in the Kiowa-WolfComanche Creeks Area in Central Adams County, Colorado; M. S. Thesis, Department of Geology, Colorado State University.

Sato, Yoshiaki and Denson, N. M., 1967; Volcanism and Tectonism as Reflected by the Distribution of Nonopaque Heavy Minerals in Some Tertiary Rocks of Wyoming and Adjacent States; U. S. Geo1. Survey, Prof. Paper 575-C, p. C42-C54.

Schulz, E. R. and Smith, G. L., 1962; Normal Monthly and Annual Precipitation for Eastern Colorado; Colorado State University, CER62GLS48.

Scott, G. R. and Cobban, W. A., 1959; So Called Hygiene Group of Northeastern Colorado: Symposium on Cretaceous Rocks of Colorado and Adjacent Areas; Rocky Mtn. Assoc. of Geo1., p. 124-131.

Scroggs, D. L., 1971; Bedrock Stratigraphy in Black Squirrel Creek Basin, E1 Paso County, Colorado; M. S. Thesis, Department of Geology, Colorado State University, Fort Collins, Colorado.

Soister, P. E., 1968; Geologic Map of the Hanover NW Quadrangle, E1 Paso County, Colorado; U. S. Geo1. Survey Geo1. Quad. Map GQ-725.

Spané, F., 1971; Hydrogeologic Studies Near Akron, Colorado; Department of Geology, Colorado State University, Fort Collins, Colorado.

Stettner, P., 1968; Aquifer Models: Mathematical and Physica1; Thesis Presented to Colorado State University, Fort Collins, Colorado.

Texas Tech. University Water Resources Center, 1970; Mathematical Management Model of an Unconfined Aquifer; Final Report; OWRR Grant No. 14-01-0001-1993.

Varnes, D. J. and Scott, G. R., 1967; General and Engineering Geology of the United States Air Force Academy Site, Colorado; U. S. Geol. Survey Prof. Paper 551, 90 p.

Waltz, J. P., 1970; Water Transfer at Bedrock-Alluvium Contacts; Proc. Ogallala Aquifer Symposium, Spec. Rept. No. 39, Texas Tech. Univ., Lubbock, Texas.

Ward, A., Sr., 1970; Personal Communication, Akron, Colorado.

Weimer, R. J., 1959; Upper Cretaceous Stratigraphy, Colorado: Symposium on Cretaceous Rocks of Colorado and Adjacent Areas; Rocky Mtn. Assoc. of Geol., p. 9-16.

Weist, W. G., Jr., 1964; Geology and Ground-Water Resources of Yuma County, Colorado; U. S. Geol. Survey, Water Supply Paper 1539-J, $56 \mathrm{p}$. 
Woodward, Clyde, Sherard and Associates, 1964- ; Ground Water Conditions in the Ellicott Aquifer, Cherokee Water District; Woodward, Clyde, Sherard and Assoc., Denver, Colorado.

Woodward, Clyde, Sherard and Associates, 1966; Geologic and Ground Water Study of the Northern Portion of the Colorado High Plains; Prepared for the Colorado Water Conservation Board, Denver, Colorado, 40 p. 